Prepared in cooperation with the Santa Barbara County Water Agency

\title{
Construction of 3-D Geologic Framework and Textural Models for Cuyama Valley Groundwater Basin, California
}

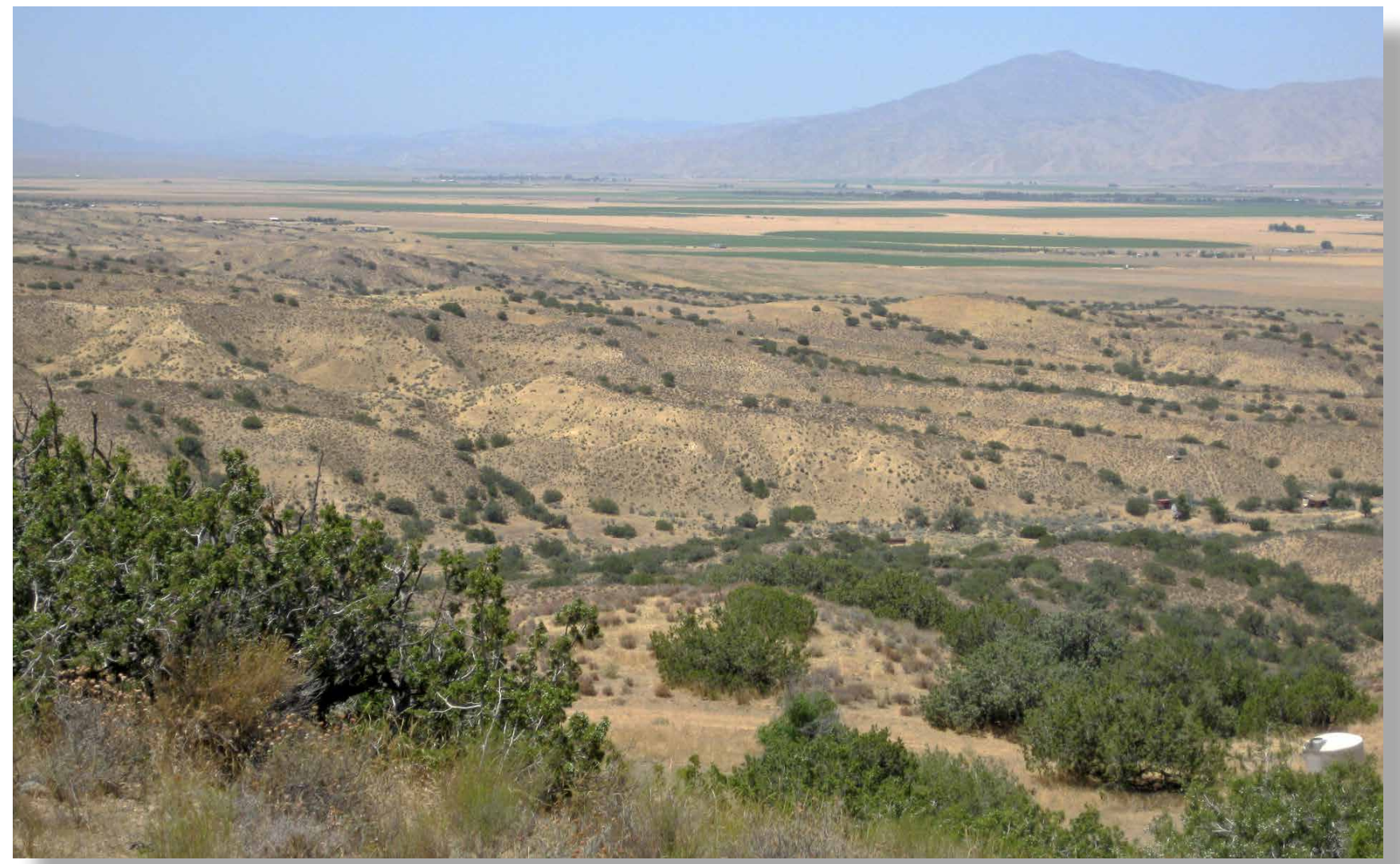

Scientific Investigations Report 2013-5127 
Cover. Looking northwest from the south side of Cuyama Valley to the Caliente Range. Photograph taken by Donald S. Sweetkind, U.S. Geological Survey, August 2, 2011. 


\section{Construction of 3-D Geologic Framework and Textural Models for Cuyama Valley Groundwater Basin, California}

By Donald S. Sweetkind, Claudia C. Faunt, and Randall T. Hanson

Prepared in cooperation with the Santa Barbara County Water Agency

Scientific Investigations Report 2013-5127 


\title{
U.S. Department of the Interior Sally Jewell, Secretary
}

\section{U.S. Geological Survey \\ Suzette M. Kimball, Acting Director}

\author{
U.S. Geological Survey, Reston, Virginia: 2013
}

For more information on the USGS - the Federal source for science about the Earth, its natural and living resources, natural hazards, and the environment, visit http://www.usgs.gov or call 1-888-ASK-USGS.

For an overview of USGS information products, including maps, imagery, and publications, visit http://Www.usgs.gov/pubprod.

To order this and other USGS information products, visit http://store.usgs.gov.

Any use of trade, firm, or product names is for descriptive purposes only and does not imply endorsement by the U.S. Government.

Although this information product, for the most part, is in the public domain, it also may contain copyrighted materials as noted in the text. Permission to reproduce copyrighted items must be secured from the copyright owner.

Suggested citation:

Sweetkind, D.S., Faunt, C.C., and Hanson, R.T., 2013, Construction of 3-D geologic framework and textural models for Cuyama Valley groundwater basin, California: U.S. Geological Survey Scientific Investigations Report 2013-5127, 46 p. 


\section{Contents}

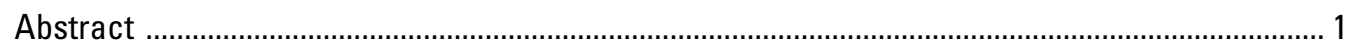

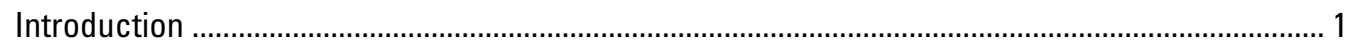

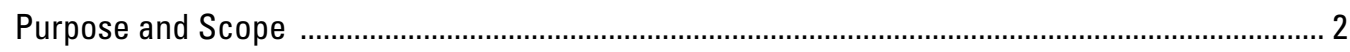

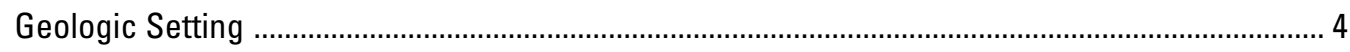

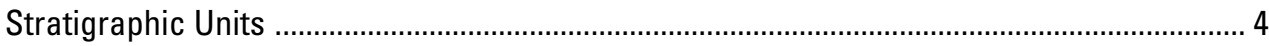

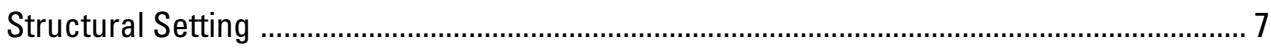

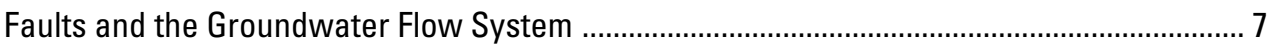

Regional Tectonics and Uplift Rates .............................................................................. 8

Compilation of Surface and Subsurface Data ......................................................................... 9

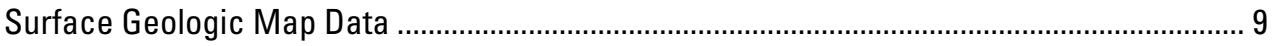

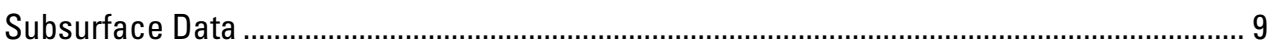

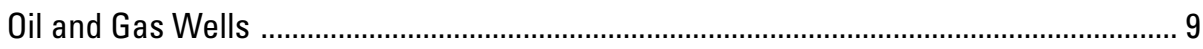

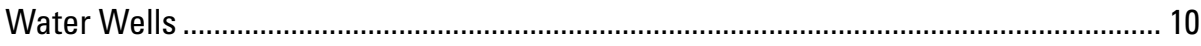

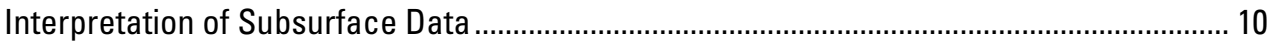

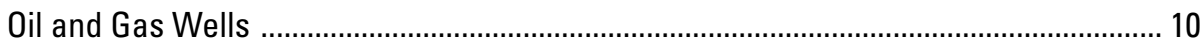

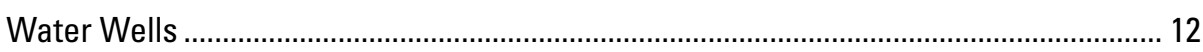

Compilation of Stratigraphic Tops from Well Data ……................................................ 12

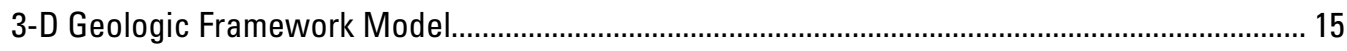

Modeling Approach.................................................................................................... 15

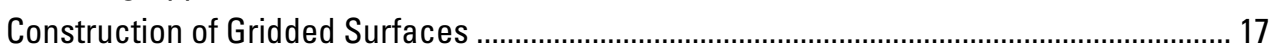

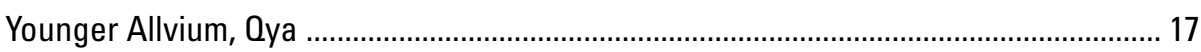

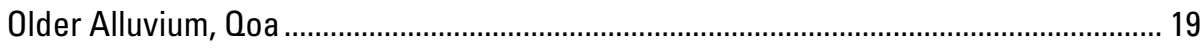

Morales Formation, OTm ........................................................................................ 20

Pre-Morales Formation (OTm) Bedrock..................................................................... 21

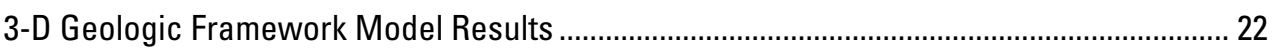

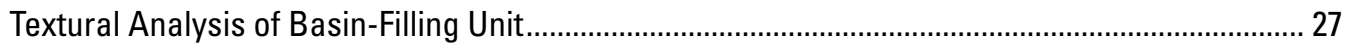

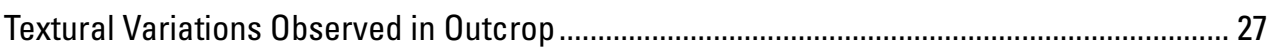

Texture Derived from Drill-Hole Data …………………........................................................ 29

Oil and Gas Wells

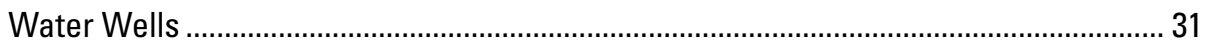

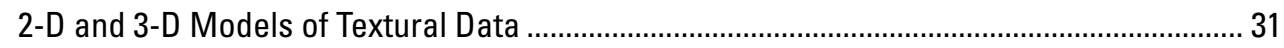

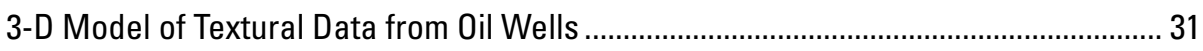

2-D Models of Textural Data ......................................................................................... 33

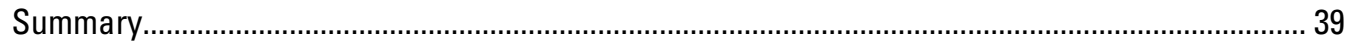

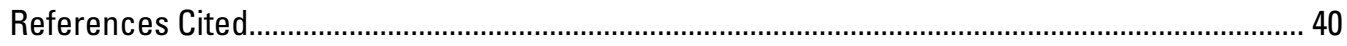

Appendix 1. Interpreted depth to top of geologic units in oil and gas wells, Cuyama Valley ....... 43

Appendix 2. Interpreted depth to top of geologic units in water wells, Cuyama Valley ................ 44

Appendix 3. Sediment textural characteristics interpreted from electric logs from oil and

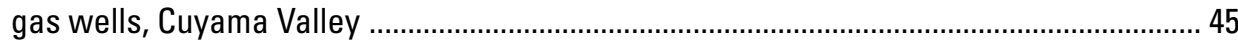

Appendix 4. Sediment textural characteristics interpreted from drillers' lithologic logs from

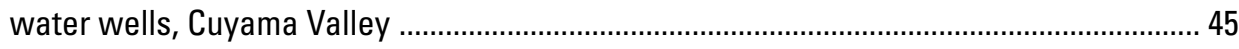




\section{Figures}

1. Map showing location of Cuyama Valley within the California Coast Ranges .................... 2

2. Map showing the Cuyama Valley study area ………………………………….................. 3

3. Generalized stratigraphic diagram of the Cuyama Valley study area ................................. 4

4. Map showing generalized geology of the Cuyama Valley study area ................................... 5

5. Composite electric log from the Cuyama Valley study area ............................................... 11

6. Correlation of electric logs from the central part of the Cuyama Valley study area ......... 13

7. Three-dimensional (3-D) perspective view of geologic units in water wells and oil

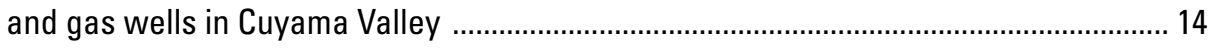

8. Diagrammatic cross section showing relative elevation of stratigraphic unit tops and resultant thickness within the framework model .................................................. 16

9. Conceptualization of the elevation and thickness of unit Qoa within the geologic framework model for the western part of the study area .............................................. 17

10. Map showing modeled thickness of the younger alluvium, Oya ........................................ 18

11. Map showing the modeled elevation of the top of the older alluvium, Qoa ...................... 19

12. Map showing geologic data used to map the top of the Morales Formation, QTm .......... 20

13. Map showing modeled elevation of the top of the Morales Foramtion, QTm .................... 21

14. Map showing geologic data used to map the top of the pre-Morales Formation (OTm) bedrock ........................................................................................................ 22

15. Map showing modeled elevation of the top of bedrock ................................................. 23

16. Perspective views of vertical slices through the geologic framework model ....................24

17. Cross sections showing previous hydrogeologic interpretation and elevation of stratigraphic unit tops from the geologic framework model. $A$, east-west

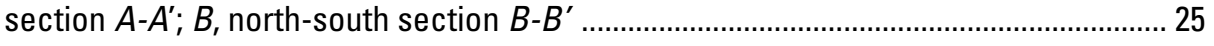

18. Map showing location of wells used for textural analysis in Cuyama Valley .................... 27

19. Photographs showing outcrop expression of textural variations in basin-filling units: $A$, Morales Formation; $B$, Older alluvium .......................................................... 28

20. Example electric log from oil and gas well showing derivation of textural data ................ 30

21. Perspective view showing results of $3-D$ textural modeling from oil and gas

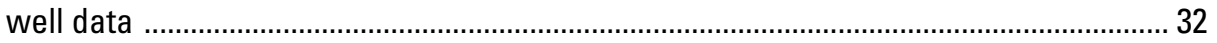

22. Map showing kriged result of textural analysis for younger alluvium, Oya ........................35

23. Map showing kriged result of textural analysis for older alluvium, Ooa ........................... 36

24. Map showing kriged result of textural analysis for the Morales Formation, QTm ............. 37

25. Perspective view showing result of kriged textural models for the younger alluvium, older alluvium, and Morales Formation units (0ya, 0oa, and 0Tm) along two vertical sections

\section{Tables}

1. Correspondence between map units from source geologic maps to geologic units ..........6 6

2. Geologic units affected by Cuyama Valley faults ............................................................ 17

3. Summary of logs used for textural analysis by geologic unit ........................................... 33

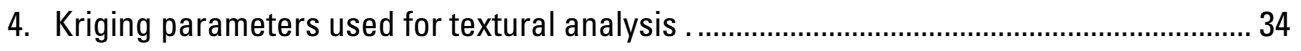


Conversion Factors, Datums, and Abbreviated Water-Quality Units

Inch/Pound to SI

\begin{tabular}{lcl}
\hline \multicolumn{1}{c}{ Multiply } & By & \multicolumn{1}{c}{ To obtain } \\
\hline & Length & \\
\hline foot $(\mathrm{ft})$ & 0.3048 & meter $(\mathrm{m})$ \\
mile (mi) & 1.609 & kilometer $(\mathrm{km})$ \\
\hline \multicolumn{3}{c}{ Volume } \\
\hline barrel (bbl), (petroleum, 1 barrel=42 gal) & 0.1590 & cubic meter $\left(\mathrm{m}^{3}\right)$ \\
\hline & Flow rate & \\
\hline gallon per minute $(\mathrm{gal} / \mathrm{min})$ & 0.06309 & liter per second $(\mathrm{L} / \mathrm{s})$ \\
inch per year $($ in $/ \mathrm{yr})$ & 25.4 & millimeter per year $(\mathrm{mm} / \mathrm{yr})$ \\
\hline & Specific capacity & \\
\hline gallon per minute per foot $[(\mathrm{gal} / \mathrm{min}) / \mathrm{ft})]$ & 0.2070 & liter per second per $\mathrm{meter}[(\mathrm{L} / \mathrm{s}) / \mathrm{m}]$ \\
\hline
\end{tabular}

Vertical coordinate information is referenced to the National Geodetic Vertical Datum of 1988 (NGVD 88).

Horizontal coordinate information is referenced to the North American Datum of 1983 (NAD 83).

Altitude, as used in this report, refers to distance above the vertical datum. 


\section{Abbreviations}

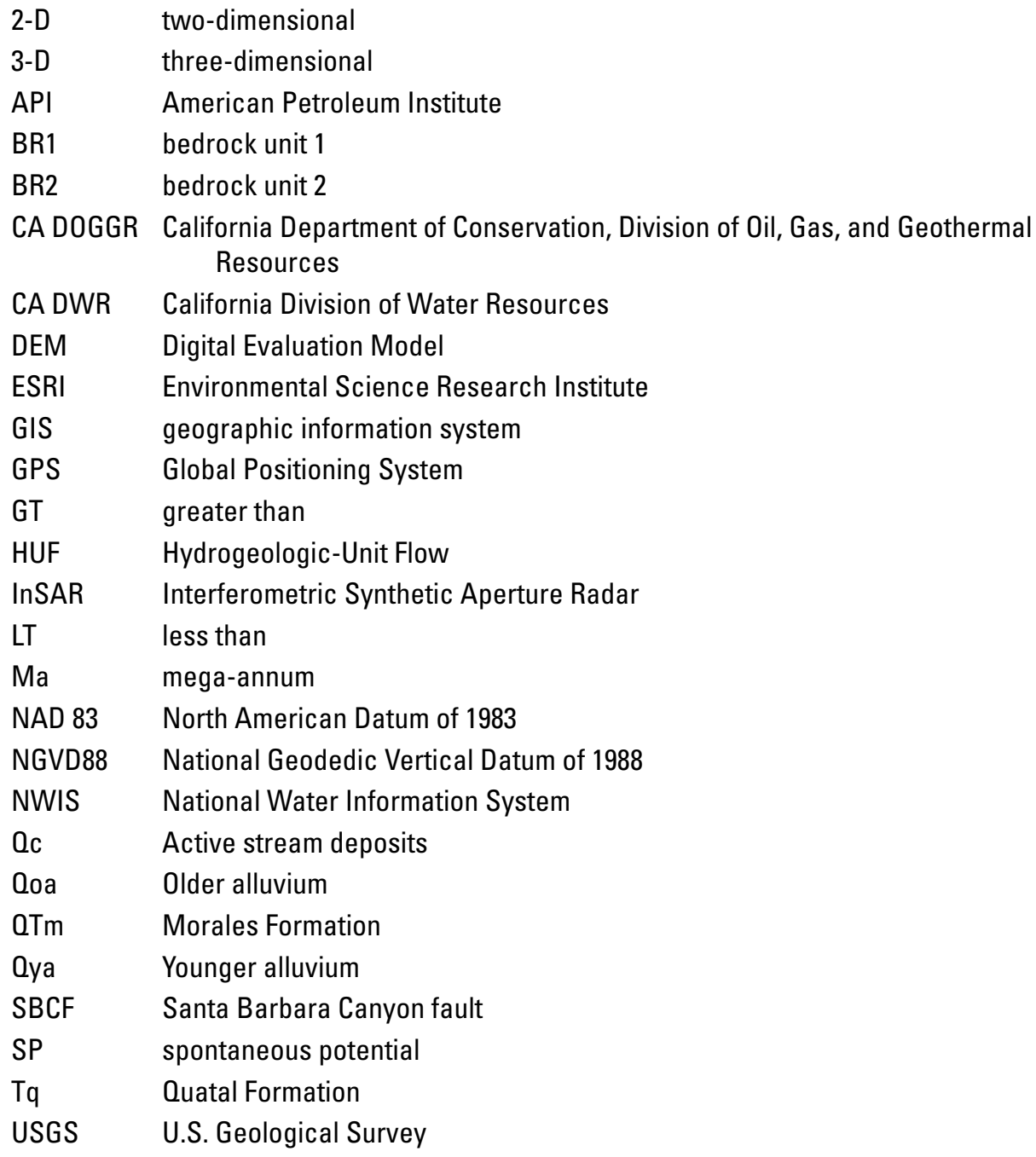




\section{Acknowledgments}

Emily Taylor, U.S. Geological Survey, Denver; Meghan Patterson, Metropolitan State College of Colorado; and Lauren Shumaker, University of California-Santa Cruz, transcribed paper drill-hole records into digital files, and Shumaker assigned textural parameters to down-hole lithologic intervals on the basis of analysis of geophysical electric logs.

Staff at the U.S. Geological Survey California Water Science Center, San Diego District Office, digitized electric logs, georeferenced scanned large-format plates, and provided accurate locations for water wells in the valley. In addition to U.S. Geological Survey technical reviews, a draft of this report was improved by comments and insight and informal reviews from Victoria Langenhiem and Daniel Scheirer of the U.S. Geological Survey and from Dennis Gibbs of Santa Barbara County Department of Public Works, California. Funding for this study provided in part from the U.S. Geological Survey National Cooperative Geologic Mapping Program. 


\title{
Construction of 3-D Geologic Framework and Textural Models for Cuyama Valley Groundwater Basin, California
}

\author{
By Donald S. Sweetkind, Claudia C. Faunt, and Randall T. Hanson
}

\section{Abstract}

Groundwater is the sole source of water supply in Cuyama Valley, a rural agricultural area in Santa Barbara County, California, in the southeasternmost part of the Coast Ranges of California. Continued groundwater withdrawals and associated water-resource management concerns have prompted an evaluation of the hydrogeology and water availability for the Cuyama Valley groundwater basin by the U.S. Geological Survey, in cooperation with the Water Agency Division of the Santa Barbara County Department of Public Works. As a part of the overall groundwater evaluation, this report documents the construction of a digital three-dimensional geologic framework model of the groundwater basin suitable for use within a numerical hydrologic-flow model. The report also includes an analysis of the spatial variability of lithology and grain size, which forms the geologic basis for estimating aquifer hydraulic properties.

The geologic framework was constructed as a digital representation of the interpreted geometry and thickness of the principal stratigraphic units within the Cuyama Valley groundwater basin, which include younger alluvium, older alluvium, and the Morales Formation, and underlying consolidated bedrock. The framework model was constructed by creating gridded surfaces representing the altitude of the top of each stratigraphic unit from various input data, including lithologic and electric logs from oil and gas wells and water wells, cross sections, and geologic maps.

Sediment grain-size data were analyzed in both two and three dimensions to help define textural variations in the Cuyama Valley groundwater basin and identify areas with similar geologic materials that potentially have fairly uniform hydraulic properties. Sediment grain size was used to construct three-dimensional textural models that employed simple interpolation between drill holes and two-dimensional textural models for each stratigraphic unit that incorporated spatial structure of the textural data.

\section{Introduction}

Cuyama Valley is a rural agricultural area about 55 kilometers $(\mathrm{km})$ north of Santa Barbara and approximately $65 \mathrm{~km}$ southwest of Bakersfield, California, in the southeasternmost part of the Coast Ranges of California (fig. 1). It lies west of the San Joaquin Valley and north of the west-trending Transverse Ranges (fig. 1). The valley is bounded on the north by the Caliente Range and on the southwest by the Sierra Madre Mountains, and it is drained by the Cuyama River (fig. 2). Cuyama Valley sits at the intersection of four counties: most of the valley is within Santa Barbara and San Luis Obispo Counties, regions near the headwaters of the Cuyama River lie in Ventura County, and a small eastern part of the Valley lies within Kern County (fig. 2). Although located within the Coast Ranges, Cuyama Valley has many of the climatic features of a desert basin because it is far from the coast and surrounded by relatively high mountains. The main economic activities in Cuyama Valley are ranching, agriculture, and oil and gas production.

Topographically, Cuyama Valley overlies and is part of a broader geologic domain, which was a depocenter for marine and nonmarine sediments during the Oligocene and Miocene epochs (Lagoe, 1984, 1987; Bazeley, 1988; Fritsche, 1988) and for continental deposits and alluvial sediments several hundred meters-thick during the Pliocene and Pleistocene epochs (Vedder and Repenning, 1975; Ellis and others, 1993). These continental deposits and alluvial sediments constitute the principal groundwater aquifer of the Cuyama Valley groundwater basin (California Department of Water Resources, 2003; fig. 2). Groundwater is currently the sole source of water supply for Cuyama Valley. Groundwater withdrawal, mainly for the irrigation of crops, has resulted in water-level declines of as much as 100 meters (m) since the 1940s (Singer and Swarzenski, 1970; Pierotti and Lewy, 1998). Groundwater is found in permeable Holocene alluvial fill and underlying less permeable Pliocene-Pleistocene continental deposits (Upson and Worts, 1951; California Department of Water Resources, 2003). In areas where drawdown is greatest, water-level declines have left the more productive shallow aquifers unsaturated and have dropped the water table into the less-productive, deeper aquifers. In response to these changes, the U.S. Geological Survey (USGS), in cooperation with the Water Agency Division of the Santa Barbara County 


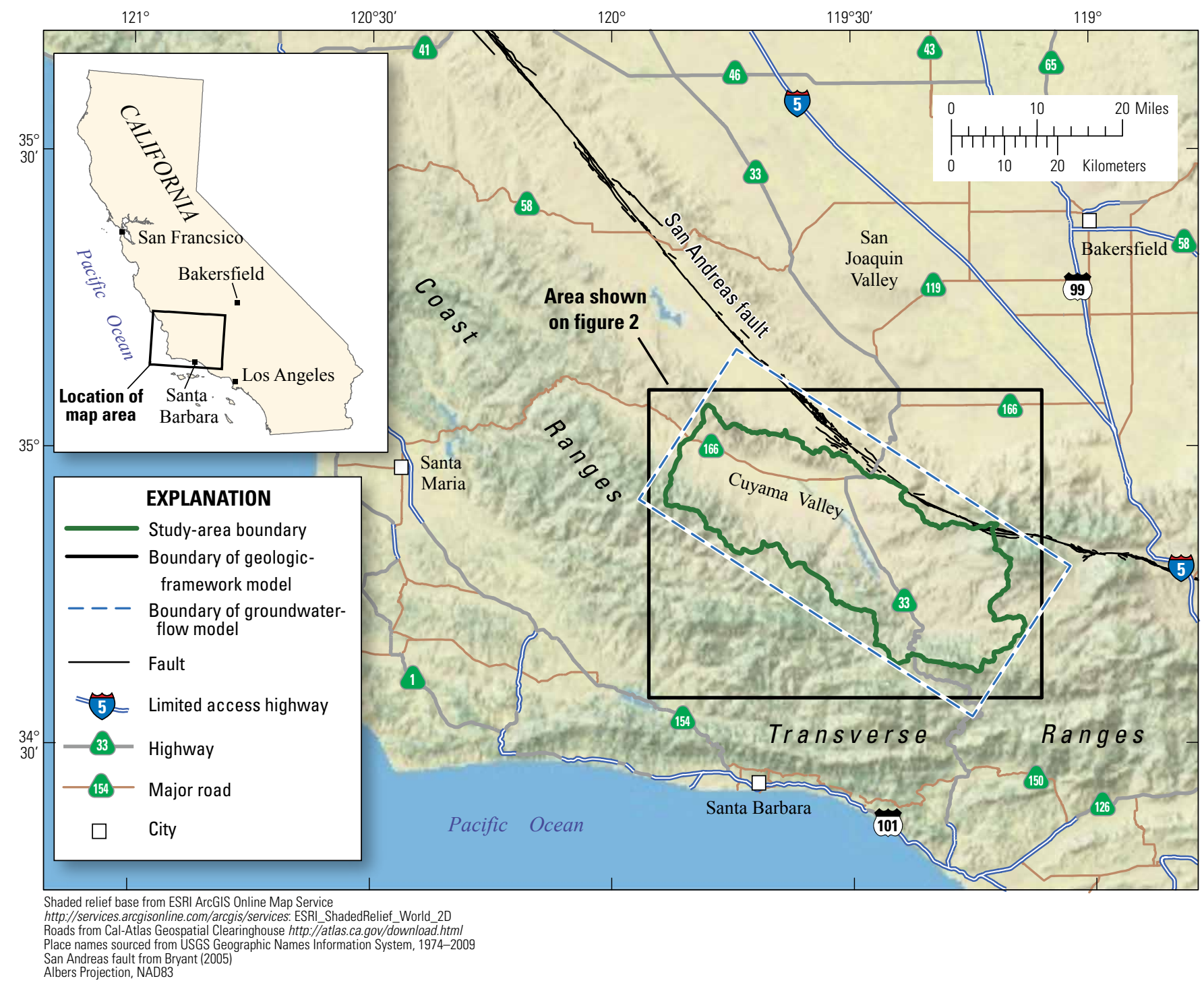

Figure 1. Location of Cuyama Valley within the California Coast Ranges.

Department of Public Works, is evaluating the hydrogeology and water availability of the groundwater basin. The intent of the overall study is to develop a greater understanding of the occurrence and availability of groundwater and to evaluate the potential effects of future groundwater withdrawals on different parts of the valley.

An evaluation and simulation of groundwater resources are most effectively achieved through an understanding of the subsurface geologic framework through which the water moves. As a part of the overall groundwater evaluation of Cuyama Valley, this report provides a conceptual understanding of the geologic setting of the Cuyama Valley groundwater basin and documents the construction of three-dimensional (3-D) digital models of the geologic framework and grainsize variations within the study area. These data provide the physical geologic framework that is used within a numerical hydrologic-flow model being developed concurrently (Randall Hanson, U.S. Geological Survey, written commun., 2013).

\section{Purpose and Scope}

This report describes the geology in the vicinity of Cuyama Valley, with an emphasis on the Pliocene through Holocene terrestrial sediments that have the greatest bearing on the Cuyama Valley groundwater basin. This report documents the use of surface and subsurface geologic data in the construction of a digital 3-D geologic framework model of the basin. The 3-D model is the digital representation of the interpreted geometry and thickness of subsurface geologic units and the geometry of folds and faults that bound the basin and lie within it. Previous work has outlined the overall shape of the basin and geometry of faulting along specific geologic profiles across the basin (Singer and Swarzenski, 1970; Vedder and Repenning, 1975; Davis and others, 1988), but the 3-D geometry of the geologic units must be defined for the purposes of the numerical flow model. Most previous geologic 


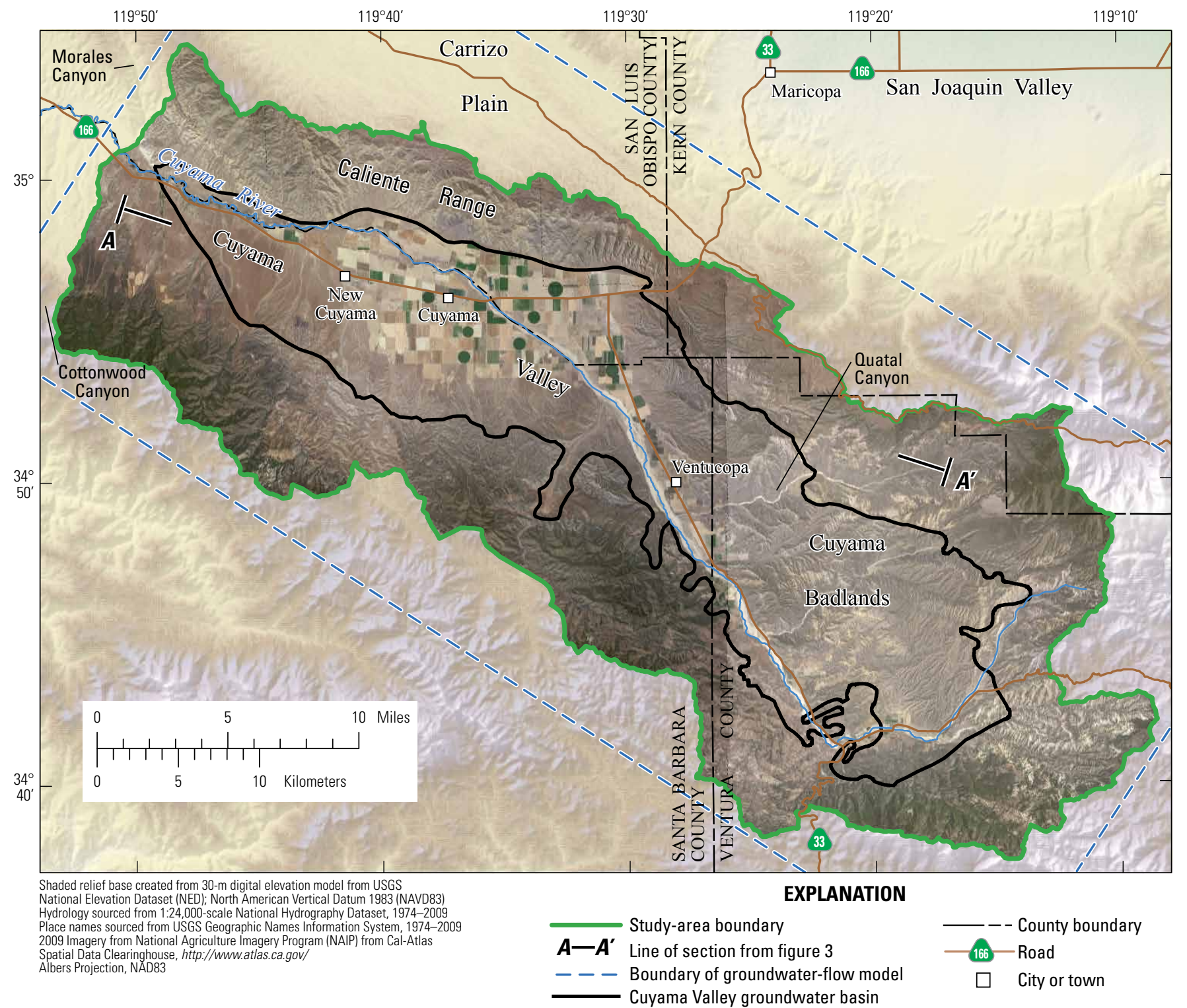

Figure 2. The Cuyama Valley study area.

investigations in Cuyama Valley have focused on the deeper, oil-bearing rocks (Hill and others, 1958; Lagoe, 1987; Bartow, 1990). Here, the geologic framework model uses information from a variety of datasets, including existing lithologic and electrical geophysical logs from oil and gas wells and water wells, cross sections, and geologic maps, to delineate the volumes of the aquifer system bounded by faults and relevant depositional or formational boundaries.

This report also documents the development of the 3-D spatial distribution of grain size of the basin-filling deposits. Textural characteristics such as grain size form the basis by which aquifer hydraulic properties are assigned within the numerical hydrologic-flow model (Hanson and others, 2003, 2004; Faunt, 2009). Previous USGS studies of Cuyama Valley (Upson and Worts, 1951; Singer and Swarzenski, 1970) delineated aquifers in the saturated parts of the younger and older alluvium, which are the units that, historically, have yielded most of the water pumped in the study area. Since these studies were completed, water levels have declined in some areas into the deeper formations, such as the Morales Formation, that were not previously investigated in detail, requiring an investigation of the geometry and water-bearing properties of all of the basin-filling units, including the deeper stratigraphic sections of the groundwater basin.

The focus of this investigation is the alluvial basin that underlies the valley and constitutes the principal groundwater reservoir beneath Cuyama Valley and adjacent areas at the basin margins, where Pliocene and younger continental sediments are exposed in outcrop and could serve as active recharge areas for the groundwater basin. The study area of interest thus includes the agricultural areas between the town of New Cuyama on the west and State Highway 33 on the east (fig. 2) and the part of the Cuyama River drainage extending southeastward along the Cuyama River to its headwaters south 
of the Cuyama Badlands (fig. 2). The western boundary of the study area is located in the vicinity of the tributary washes of Morales Canyon on the north and Cottonwood Canyon on the south (fig. 2) to include all thick occurrences of young alluvium (Upson and Worts, 1951; Vedder and Repenning, 1975).

Although the Cuyama Valley groundwater basin is the primary interest of this study, for computational reasons the geologic framework model covers a large rectangular area slightly larger than the boundaries of figure 2 , and thus includes much bedrock of little hydrologic interest. The overall hydrogeologic evaluation of Cuyama Valley involves the use of a numerical hydrologic-flow model and a linked watershed model; the boundary of this numerical simulation forms an elongate, northwest-trending rectangular polygon aligned with the valley axis (fig. 2).

\section{Geologic Setting}

Aquifer units within the Cuyama Valley groundwater basin include unconsolidated Pleistocene and Holocene alluvial deposits and fluvial deposits of the Cuyama River drainage and the underlying partly consolidated nonmarine Morales Formation of Pliocene to Pleistocene age (Upson and Worts, 1951; Singer and Swarzenski, 1970). These deposits unconformably overlie a late Cretaceous to middle Cenozoic succession of consolidated marine and nonmarine sedimentary rocks, which themselves overlie crystalline granitic and gneissic rocks (Hill and others, 1958; Dibblee, 1982; Lagoe, 1987; Bazeley, 1988; fig. 3).
Cuyama Valley has cumulative production plus reserves of about 290 million barrels of oil (Stanley, 1995; California Department of Conservation, 2009). Most of the production comes from the South Cuyama and Russell Ranch fields, located next to the Russell fault (fig. 4; Stanley, 1995). Abundant subsurface geologic data for this study have come from oil and gas wells from these fields and from exploration holes scattered across the valley (Nevins, 1982; Schwing, 1984; Calhoun, 1986; Spitz, 1986; Sweetkind and others, 2013).

\section{Stratigraphic Units}

The shallow alluvial section is subdivided into three units: Qc, fluvial channel deposits associated with the Cuyama River; Qya, younger alluvium; and Qoa, older alluvium (figs. 3 and 4; table 1). Previous studies did not separate the younger and older alluvium as separate units (Upson and Worts, 1951; Singer and Swarzenski, 1970), but the two are distinguishable as mappable units at the surface (fig. 4) and, in the subsurface, can often be identified by differences in electric log signature.

Younger alluvium (Qya, figs. 3 and 4) consists of unconsolidated sand, gravel, and boulders, with some clay, deposited as alluvium in stream channels, floodplains, alluvial fans, and stream terraces. The unit is mainly Holocene in age, but locally can be late Pleistocene in part. Active stream deposits (Qc, figs. 3 and 4) consist of river-bed gravels of the Cuyama River and other active channels (Vedder and Repenning, 1975; DeLong and others, 2008, 2011). These deposits are incorporated into Qya within the geologic framework model.

$\boldsymbol{A}$

NW Cuyama Valley C Cuyama Valley

Cuyama Badlands

Quatal Canyon

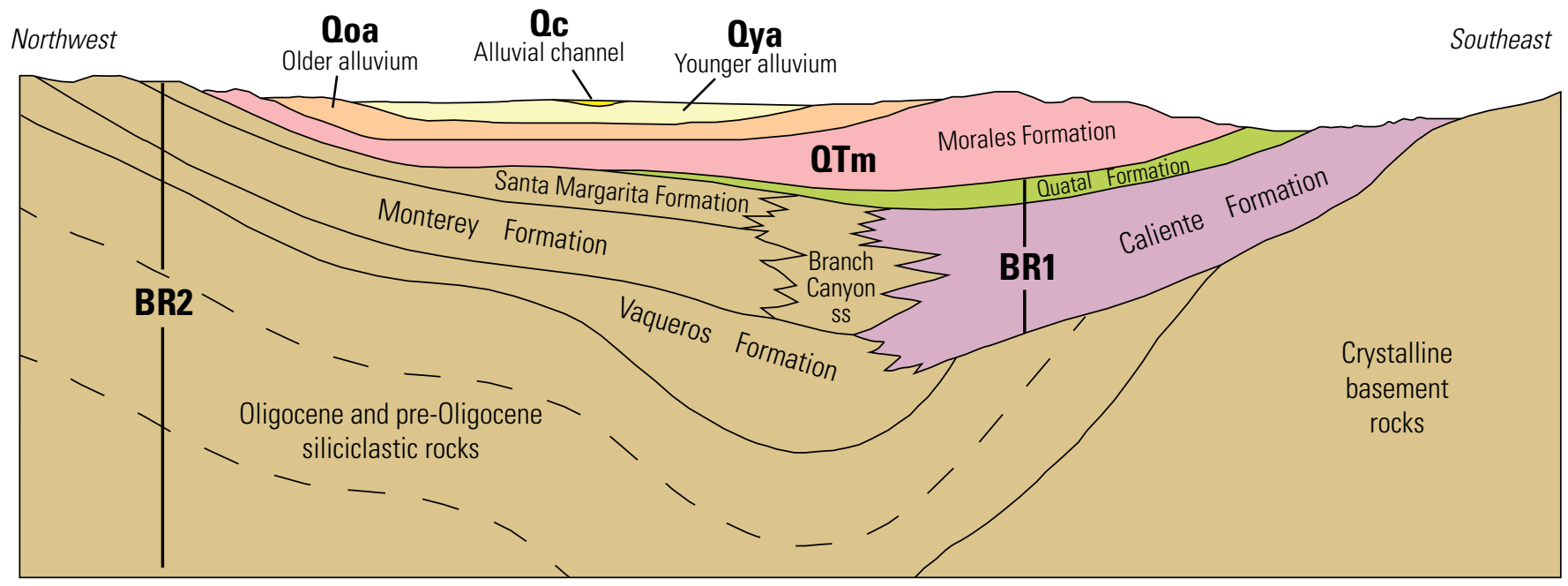

DIAGRAMMATIC, NOT TO SCALE

Approximate line of section shown on figure 2

Figure 3. Generalized stratigraphic diagram of the Cuyama Valley study area. 
Older alluvium (Qoa, figs. 3 and 4) consists of unconsolidated to partly consolidated sand, gravel, and boulders, with some clay, and the percentage of clay increases in the western part of the valley (Singer and Swarzenski, 1970; Vedder and Repenning, 1975; DeLong and others, 2008). Interpretation of geophysical logs from oil-exploration wells indicates that this unit is typically 125 to $200 \mathrm{~m}$ thick, but as thick as $300 \mathrm{~m}$ near the axis of Cuyama Valley (Schwing, 1984; Spitz, 1986). In the study area, older alluvium includes dissected alluvial fans, colluvial deposits, and sediments on multiple terraces and alluvial surfaces (Hill and others, 1958; DeLong and others,
2008). Older alluvium is exposed on uplifted alluvial surfaces along the south side of Cuyama Valley and in the center of the valley along the Turkey Trap and Graveyard Ridge faults (fig. 4; Vedder and Repenning, 1975; DeLong and others, 2008). A greater degree of consolidation, dissection, and local deformation distinguishes the older alluvial deposits from young alluvium in outcrop.

The Pliocene-Pleistocene Morales Formation (QTm, figs. 3 and 4) is an alluvial and fluvial deposit throughout most of the study area. The unit is as thick as $1,500 \mathrm{~m}$ and consists of massive- to thick-bedded, partly consolidated deposits of gravelly

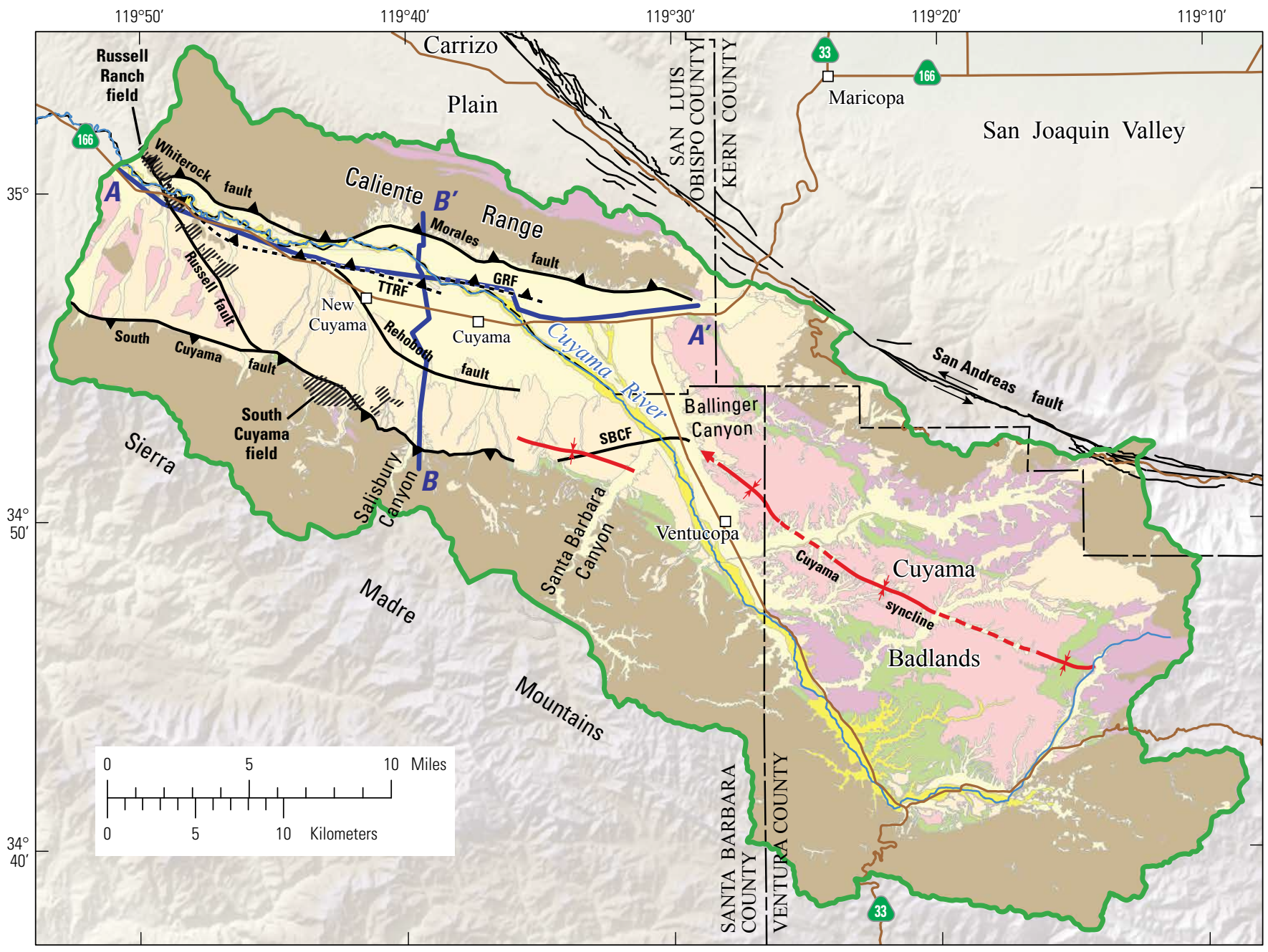

Shaded relief base created from 30-m digital elevation model from USGS National Elevation Dataset (NED); North American Vertical Datum 1983 (NAVD83) Hydrology sourced from 1:24,000-scale National Hydrography Dataset, 1974-2009 Place names sourced from USGS Geographic Names Information System, 1974-2009 San Andreas fault from Bryant (2005). Albers Projection, NAD83

Generalized stratigraphic units

Qc, active channel Oya, young alluvium

Qoa, older alluvium

QTm, Morales Formation

BR1, Quatal Formation

BR1, Caliente Formation

BR2, bedrock unit 2

\section{EXPLANATION}

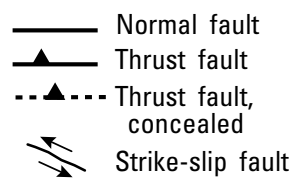

GRF, Graveyard Ridge fault;

SBCF, Santa Barbara Canyon fault:

TTRF, Turkey Trap Ridge fault

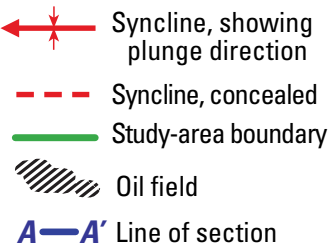

Figure 4. Generalized geology of the Cuyama Valley study area. 
Table 1. Correspondence between map units from source geologic maps to geologic units.

\begin{tabular}{|c|c|c|c|}
\hline $\begin{array}{l}\text { Geologic unit } \\
\text { (abbreviation) }\end{array}$ & Unit description & $\begin{array}{l}\text { Corresponding geologic units } \\
\text { (Kellogg and others, 2008) }\end{array}$ & $\begin{array}{l}\text { Corresponding geologic units } \\
\text { (Graham and others, 1999) }\end{array}$ \\
\hline $\begin{array}{l}\text { Quaternary channel } \\
\text { deposits (Qc) }\end{array}$ & $\begin{array}{l}\text { Includes active channel of the Cuyama River and } \\
\text { recent meander cutoffs. }\end{array}$ & Qa, active alluvium. & Not shown \\
\hline $\begin{array}{l}\text { Younger alluvium } \\
\text { (Qya) }\end{array}$ & $\begin{array}{l}\text { Young unconsolidated alluvium on valley floor and in } \\
\text { tributary washes. }\end{array}$ & Qya, younger (inactive) alluvium. & Qa, alluvium \\
\hline $\begin{array}{l}\text { Older alluvium } \\
\text { (Qoa) }\end{array}$ & $\begin{array}{l}\text { Older alluvial deposits, partly consolidated. Dissected } \\
\text { and deformed into gentle folds. }\end{array}$ & $\begin{array}{l}\text { Qoa, older alluvium; } \\
\text { QTa, old alluvium, locally deformed. }\end{array}$ & Qoa, older alluvium \\
\hline $\begin{array}{l}\text { Morales Formation } \\
\quad(\mathrm{QTm})\end{array}$ & $\begin{array}{l}\text { Weakly to moderately indurated arkosic, lithic sand- } \\
\text { stone and conglomerate. Fine-grained lacustrine } \\
\text { facies in western part of study area. }\end{array}$ & $\begin{array}{l}\text { QTm and subunits, Morales Formation; } \\
\text { QTt, Tulare Formation }\end{array}$ & $\begin{array}{l}\text { Tmo, Morales Formation; } \\
\text { QTp, Paso Robles Formation }\end{array}$ \\
\hline $\begin{array}{l}\text { Quatal Formation } \\
\qquad(\mathrm{Tq})\end{array}$ & $\begin{array}{l}\text { Predominantly fine-grained fluvial to lacustrine } \\
\text { siltstone and fine-grained sandstone. Underlies } \\
\text { Morales Formation in eastern half of the study area, } \\
\text { pinches to zero thickness in the vicinity of the town } \\
\text { of Cuyama. }\end{array}$ & $\begin{array}{l}\text { Tq and subunits, Quatal Formation; } \\
\text { Tlc, Lockwood Clay. }\end{array}$ & Tq, Quatal Formation. \\
\hline $\begin{array}{l}\text { Bedrock unit } 1 \\
\quad(\mathrm{BR} 1)\end{array}$ & $\begin{array}{l}\text { Continental sedimentary rocks of the Caliente Forma- } \\
\text { tion. In the subsurface the Caliente Formation inter- } \\
\text { fingers westward with Middle Miocene consolidated } \\
\text { marine rocks. }\end{array}$ & Tc and subunits, Caliente Formation. & Tc, Caliente Formation. \\
\hline $\begin{array}{l}\text { Bedrock unit } 2 \\
\quad(\mathrm{BR} 2)\end{array}$ & $\begin{array}{l}\text { Includes all Miocene and older consolidated bedrock } \\
\text { units (except for continental Caliente Formation). } \\
\text { Tertiary basalts that are interbedded with Caliente } \\
\text { Formation in the Caliente Range were included in } \\
\text { this unit. }\end{array}$ & $\begin{array}{c}\text { Tcb, Alkalic olivine basalt flow; } \\
\text { Ti, Intrusive olivine diabase; } \\
\text { Tsm and subunits, Santa Margarita } \\
\text { Sandstone; } \\
\text { Tb and subunits, Branch Canyon } \\
\text { Sandstone; } \\
\text { Tm and subunits, Monterey Formation; } \\
\text { Tv and subunits, Vaqueros Formation; } \\
\text { all older units. }\end{array}$ & $\begin{array}{c}\text { Tb, basalt; } \\
\text { Tsm and subunits, Santa Margarita } \\
\text { Formation; } \\
\text { Tbs, Branch Canyon Sandstone; } \\
\text { Tm and subunits, Monterey Formation; } \\
\text { Tv and subunits, Vaqueros Formation; } \\
\text { all older units. }\end{array}$ \\
\hline
\end{tabular}

arkosic sand with local gravel beds and siltstone (Hill and others, 1958; Ellis and others, 1993; DeLong and others, 2008, 2011; Kellogg and others, 2008). In the western part of the study area, the unit is predominantly fine-grained and consists chiefly of lacustrine clay (Upson and Worts, 1951; Dibblee and Minch, 2005d; DeLong and others, 2008). The Morales Formation is widely exposed as badland topography east of the Cuyama River (fig. 4; Dibblee, 1982; Dibblee and Minch, 2005a, 2006; Kellogg and others, 2008).

For the purposes of this study, non-water-bearing consolidated rocks that lie beneath the Morales Formation are divided into two generalized geologic units: BR1 and BR2. Most of the middle Miocene and older consolidated rocks were included in the deeper unit, bedrock unit 2 (BR2; figs. 3 and 4; table 1). This unit forms the bedrock highlands on the north, south, and east sides of the study area and includes consolidated marine and continental deposits of great thickness. Stratigraphic units that compose BR2 include the Santa Margarita Formation, the Branch Canyon Sandstone, the Monterey Formation, the Vaqueros Formation, and older rocks (fig. 3; table 1).

Continental sedimentary rocks of the Caliente Formation and the Quatal Formation were retained as a separate bedrock unit (BR1; figs. 3 and 4; table 1) because they are significantly less consolidated than the underlying units, which can result in different water-transmitting properties. The Quatal Formation is a nonmarine claystone and sandstone sequence that conformably underlies the Morales Formation (Hill and others, 1958). At its type locality in the Cuyama Badlands, it consists of about $250 \mathrm{~m}$ of gypsiferous claystone, although elsewhere in the study area, nonmarine sandstones are interbedded with the claystone (Vedder, 1968; Kellogg and others, 2008). The unit is readily identified in the subsurface throughout the eastern part of the study area as a distinctive interval on electric logs; it thins westward and pinches out beneath the central part of Cuyama Valley (fig. 3; Ellis and Spitz, 1987; Ellis, 1994). The Quatal Formation is not part of the active groundwater flow system. It is highlighted on the geologic map because, in the eastern and central parts of the study area, it is a distinctive stratigraphic marker that defines the base of the Morales Formation and the base of the groundwater system (figs. 3 and 4; table 1).

Historically, most of the water pumped from the study area was obtained from the younger and older alluvium (Singer and Swarzenski, 1970). Large-capacity wells perforated in the alluvium yield 1,000-3,000 gallons per minute (gpm) and have specific capacities in the range from 100 to $200 \mathrm{gpm}$ per foot (gpm/ft; Singer and Swarzenski, 1970). The water-bearing properties of the Morales Formation are not well defined, but available data indicate that hydraulic conductivity, the ease 
with which water passes through the formation, varies greatly both areally and with depth. Wells perforated in the Morales Formation along the northern margin of the central valley have specific capacities of $25-50 \mathrm{gpm} / \mathrm{ft}$; wells perforated in the finer-grained facies in the western part of the valley have specific capacities of 5 to $25 \mathrm{gpm} / \mathrm{ft}$ (Singer and Swarzenski, 1970). Inspection of available geologic and geophysical logs indicate that the hydraulic conductivity of the Morales Formation decreases with depth.

\section{Structural Setting}

In the Cuyama Valley region, Oligocene extension and Miocene strike-slip faulting are overprinted and obscured by Pliocene- to Pleistocene-aged thrust faults that bound the ranges surrounding the current topographic valley (Calhoun, 1986; Davis and others, 1988). Rocks of Miocene age and older are known from deep oil and gas wells to be affected by older, now inactive faults largely buried by the Morales Formation and younger units (Yeats and others, 1989). The most significant of these older faults is the Russell fault at the west edge of the study area (fig. 4). This fault localizes the oilproducing fields in Cuyama Valley by trapping petroleum in faulted updip ends of sandstones within the Miocene Vaqueros Formation (Stanley, 1995). Up to $29 \mathrm{~km}$ of right-lateral offset has been documented on the northwest-striking Russell fault in the northwest part of Cuyama Valley to have occurred between 23 and 4 mega-annum (Ma), but the fault has little to no offset in Morales Formation or younger units (Yeats and others, 1989; Ellis and others, 1993).

During Pliocene time, the deformational style in Cuyama Valley changed to a predominantly compressional mode during the deposition of the Morales Formation (Ellis and others, 1993; Ellis, 1994). Resultant deformation has created the Cuyama structural basin and produced the converging thrust faults that bound Cuyama Valley: the south-directed Whiterock and Morales faults on the north and the north-directed South Cuyama fault on the south (fig. 4; Vedder and Repenning, 1975; Davis and others, 1988). Based on the magnetostratigraphy of the Morales Formation, uplift of the Caliente Range began between 3.0 and 2.6 Ma (Ellis and others, 1993; Ellis, 1994). Thrust motion continued into Quaternary time, with Miocene-aged rocks of the Caliente Range to the north of Cuyama Valley being thrust southward over Quaternary alluvium on the Morales fault (Vedder and Repenning, 1975). DeLong and others (2008) report thrust-fault interaction with Quaternary piedmont deposits in the western part of the study area indicateing ongoing contraction through $0.1 \mathrm{Ma}$.

Contraction of the Cuyama structural basin is driven by transpressional forces resulting from northwest-directed transport of the crustal block containing Cuyama Valley around the Big Bend of the San Andreas fault system to the east (Argus and Gordon, 2001; Hardebeck and Michael, 2004). Geodetic results from various models indicate that the San Andreas fault system and central California Coast Ranges accommodate northwest-directed motion relative to the North American plate of about $39 \mathrm{~mm} / \mathrm{yr}$, mainly by strike-slip faulting (Meade and Hager, 2005), with a small and variable amount of faultperpendicular convergence (Argus and Gordon, 2001). The greatest amount of convergence along the length of the San Andreas fault system is in the vicinity of the Big Bend of the San Andreas fault (Argus and Gordon, 2001), an area that includes Cuyama Valley. Inversion of focal mechanisms of small earthquakes near the San Andreas fault showed that the direction of maximum horizontal compressive stress in the vicinity of the Big Bend of the San Andreas fault is between 40 and 60 degrees to the strike of the fault (Hardebeck and Michael, 2004). In the vicinity of Cuyama Valley, this direction is approximately perpendicular to the valley axis and tectonically consistent with the orientation of thrust faults that bound the north and south sides of the valley.

The Morales Formation and older alluvium are folded into tight synclines along the north and south margins of the valley near the bounding thrust faults (Spitz, 1986; Kellogg and others, 2008). The Cuyama syncline plunges northwestward beneath the valley from the Cuyama Badlands to the southeast (fig. 4; Dibblee, 1982; Ellis and Spitz, 1987; Dibblee and Minch, 2005a; 2006; Kellogg and others, 2008). It is exposed in the Ventucopa area and the Cuyama Badlands (fig. 4; Dibblee and Minch, 2005a; 2006; Kellogg and others, 2008) and is known from subsurface data from oil exploration wells beneath the valley itself (Spitz, 1986; Ellis and Spitz, 1987; Ellis, 1994).

\section{Faults and the Groundwater Flow System}

Faults of hydrologic significance in Cuyama Valley area are those that involve the aquifers. Such faults occur at the basin margin, where fault offset juxtaposes basin-fill sediments against older consolidated rocks, and within the basin, where basin-fill units of differing water-transmitting ability are juxtaposed. Faults that offset the consolidated rocks are known principally from oil and gas exploration; faults within the basin fill have been recognized previously as being associated with historic surface springs or changes in groundwater elevations (Singer and Swarzenski, 1970). Three faults within the basin offset the basin-filling deposits and are associated with known water-level changes (Upson and Worts, 1951, Singer and Swarzenski, 1970): the thrust faults that bound Turkey Trap and Graveyard Ridges, the Santa Barbara Canyon fault, and the Rehoboth fault (fig. 4).

Graveyard and Turkey Trap Ridges in the center of Cuyama Valley, north of Highway 166, trend slightly north of west, are oriented in a left-stepping, en echelon pattern and contain exposures of older alluvium (Qoa; fig. 4). Geologic mapping and north-south seismic reflection profiles collected across these ridges showed that these ridges are bounded by northdipping, south-directed, reverse faults along their south sides (Upson and Worts, 1951; Vedder and Repenning, 1975; Ellis, 1994). Upson and Worts (1951) reported the presence of 
Construction of 3-D Geologic Framework and Textural Models for Cuyama Valley Groundwater Basin, California

springs and seeps along the base of Turkey Trap and Graveyard Ridges in 1946. Singer and Swarenski (1970) reported water-level drawdowns of 80 to 100 feet (ft) in the area near these ridges and indicated that water removed by pumping from this region was slow to replenish because faults restrict movement of water from neighboring areas. The impediment to flow could be related to the hydraulic properties of the fault itself or fault juxtaposition of older, slightly less permeable Qoa, to the north, against Qya to the south of the faults.

A fault, here called the Santa Barbara Canyon fault (SBCF, fig. 4), was suggested by Singer and Swarzenski (1970) to be the cause of a steep hydraulic gradient in the southeastern part of Cuyama Valley, where water levels in the vicinity of Ventucopa are at least $30 \mathrm{~m}$ higher than water levels $3 \mathrm{~km}$ to the north. Singer and Swarzenski (1970) suggest that this fault could be a projection of east-northeast-striking faults mapped west of Santa Barbara Canyon by Dibblee and Minch (2007) on the basis of anomalous topographic lineaments in older alluvium. No geologic evidence bearing on sense or amount of offset has been found in the field, although some confirmation of faulting is provided by truncation of distinctive gravel beds in the older alluvium along the west wall of Santa Barbara Canyon, near its mouth, on trend with the lineaments. Very minor throw, southeast-side down, is indicated by distinctive markers in the Morales Formation on geophysical logs from wells on either side of the lineaments, and Dibblee and Minch (2007) showed about 1,500 m of left-lateral offset on fold axes across the lineaments. Such lateral slip on east-northeast-striking faults is consistent with the present northward-directed compressive tectonic regime of Cuyama Valley. Although a single fault is shown on figure 4 , the topographic lineaments mapped in the piedmont upland and the width of the zone where there are water-level changes indicate that there could be a zone of subparallel faults. No deep-well data constrain how these faults project northeastward across the Cuyama River; analysis of formation contacts, dip amounts, and dip directions in Ballinger Canyon on the east side of the Cuyama River reveals no obvious continuation of this fault trend. The relatively small amount of vertical offset on the Santa Barbara Canyon fault indicate that changes in water levels across this fault documented in previous studies are perhaps the result of distinct fault-zone properties, rather than juxtaposition of units of differing water-transmitting ability.

Another fault, here called the Rehoboth fault (fig. 4), is inferred from water-level changes in the west-central part of the valley. The fault is interpreted to trend southeastward near the town of Cuyama and to project beneath the Salisbury Canyon drainage (Lane-Western Company, written commun. to developers of Rehoboth Farms property, 1982). Comparison of the elevation of distinctive marker horizons within the Morales Formation on geophysical logs of exploration wells drilled on either side of the fault indicates that the top of the Morales Formation is offset about $50 \mathrm{~m}$ down on the northeast side of the fault; offset at the base of the Morales Formation is greater. Surface exposures of Qoa do not appear to be offset along the trace of the fault, indicating that motion on this fault may have ceased prior to deposition of the youngest part of Qoa.

\section{Regional Tectonics and Uplift Rates}

Geologic evidence indicates that Cuyama Valley has been the site of contractile deformation for the past $4 \mathrm{Ma}$ (Ellis and others, 1993). Geologic relations along the southern flank of the Caliente Range, which forms the northern margin of Cuyama Valley, indicate contraction until as recently as 100,000 yr (Ellis and others, 1993; DeLong and others, 2008). In addition to this shortening, ongoing compression manifests itself by broad regional tectonic uplift. Although the valley is low relative to the surrounding thrust-bounded ranges, it is elevated by $500-700 \mathrm{~m}$ relative to the San Joaquin Valley to the northeast of the San Andreas fault (Argus and Gordon, 2001). The Pliocene and Pleistocene Morales Formation was deposited within Cuyama Valley structural basin as a result of uplift along valley-margin structures, erosion of those marginal rocks, and sedimentation in the basin (Spitz, 1986; Ellis, 1994). As regional uplift continued, and the axial part of the valley narrowed, the Morales Formation and older Quaternary alluvium were themselves uplifted, exposed to fluvial erosion, and moderately deformed (Spitz, 1986; DeLong and others, 2008). On the south side of Cuyama Valley, young Quaternary deposits unconformably overlie deformed older Quaternary deposits and the Morales Formation as a result of ongoing tectonic uplift and erosion (DeLong and others, 2008; Kellogg and others, 2008). The Cuyama River and its major tributaries are currently incised into Holocene alluvium in the axial part of the valley as a result of progressive regional tectonic uplift (DeLong and others, 2008, 2011).

Continuously monitored global positioning system (GPS) stations are located in Cuyama Valley and surrounding uplands as part of an integrated GPS Network designed to monitor deformation throughout southern California (Hudnut and others, 2002; Meade and Hager, 2005). The GPS stations record variations in position and elevation that can result from either tectonic motions or from deformation associated with anthropogenic activities such as groundwater withdrawal. Landsurface position was recorded at two GPS monitoring stations within the valley - at Cuyama High School near the center of the valley and near Ventucopa in the southeastern part of the valley - and three stations in the uplands to the east, south, and southwest of the valley (Everett and others, 2013). Running 31-day averages of GPS observations acquired between 2000 and 2012 (2008-2012 for one of the upland stations) indicated a slight net upward motion at Ventucopa and the three upland stations outside the valley (Everett and others, 2013). In contrast, land surface position for the GPS station at Cuyama High School records a long-term downward trend between 2000 and 2012 with cyclic, annual seasonal variations in elevation. This cyclic variation correlates with pumping records and variations in water levels measured in nearby wells (Everett and others, 2013). It is likely that the long-term 
trend in subsidence at Cuyama High School represents inelastic, irreversible deformation of the underlying aquifer as a result of permanent changes in the pore volume and resulting loss of storage capacity within the aquifer, whereas shortterm seasonal trends represent elastic deformation associated with seasonal groundwater withdrawals (Everett and others, 2013). The magnitude of subsidence between 2002 to 2008 was estimated at five points in the central part of the valley from analysis of satellite interferometric synthetic aperture radar (InSAR) images, a remote sensing technique that can detect centimeter-level elevation changes (Everett and others, 2013). Point analysis of the InSAR images confirmed downward movement throughout the central subregions of the basin where groundwater pumpage and related water-level declines are largest (Everett and others, 2013).

\section{Compilation of Surface and Subsurface Data}

Construction of the geologic framework model utilized data from multiple sources to define the top surface and extent of each geologic unit. Input data sources include topographic data, geologic maps, stratigraphic tops interpreted from borehole data, and structure contour maps. Textural properties of the basin-filling deposits were interpreted from borehole lithologic and electric logs.

\section{Surface Geologic Map Data}

A generalized geologic map of the study area (fig. 4) was compiled through the merging of two main digital data sets: (1) a 1:100,000-scale geologic map of the eastern threequarters of the Cuyama $30^{\prime}$ x 60' quadrangle (Kellogg and others, 2008) that covers the main part of Cuyama Valley, the Cuyama Badlands, and the bedrock geology in a wide area to the south and east of Cuyama Valley, and (2) a 1:125,000-scale geologic compilation of geology along the San Andreas faults (Dibblee, 1973), as rendered digitally by Graham and others (1999), that was used to compile the geology at the northwest end of Cuyama Valley and in the Caliente Range. Larger-scale, non-digital geologic maps of parts of the basin were consulted for local geologic relations (Vedder, 1968; Vedder and Repenning, 1975; Calhoun, 1986; Dibblee and Minch, 2005a, 2005b, 2005c, 2005d, 2006, 2007).

Source geologic data were given a common map projection, and correlative geologic units from each of the source maps were merged in a geographic information system. Mapped geologic units were then combined into the limited number of geologic units of table 1.

Stream-channel deposits in the northwestern part of the area were digitized from Vedder and Repenning (1975) and from satellite imagery. Numerous landslide deposits on bedrock units were merged with the underlying bedrock unit.
Landslide deposits are generally thin (10-20 m thick) and are composed primarily of rubble from of the underlying bedrock.

Data points representing the location and elevation of stratigraphic contacts exposed in outcrop were generated from the geologic map in combination with a 1 arc-second (approximately 30-m resolution) National Elevation Dataset digital elevation model (Cal-Atlas Geospatial Clearinghouse; http://atlas.ca.gov/download.html). Regularly spaced points were digitized along a stratigraphic contact within a geographic information system (GIS). These points were assigned coordinate locations from the map base and elevations from the digital evaluation model (DEM) and exported as a series of files, one for each stratigraphic unit, containing $\mathrm{x}, \mathrm{y}$, and $\mathrm{z}$ data that were subsequently used in gridding the stratigraphic unit tops.

\section{Subsurface Data}

\section{Oil and Gas Wells}

Stratigraphic information from oil and gas exploration and development wells from Cuyama Valley, Calif., and surrounding areas have recently been compiled by Sweetkind and others (2013). Most of the oil wells in Cuyama Valley are clustered within two fields with historic and continuing production: the Russell Ranch field (Barger and Zulberti, 1952) at the west edge of the study area and the South Cuyama oil field (Zulberti, 1954) at the southwest edge of the study area (fig. 4). Production wells in those fields are very closely spaced; selected wells were used to represent geologic conditions in the vicinity of the producing fields. Exploratory wells were drilled away from the fields at widely scattered locations across Cuyama Valley. Data from every one of these exploratory wells were compiled for this study. Information on subsurface stratigraphy and lithology from over 200 oil and gas exploration wells was selected for use in the current study.

The California Department of Conservation, Division of Oil, Gas, and Geothermal Resources (CA DOGGR) maintains paper copies of electric logs on file for most of the oil and gas exploration holes in Cuyama Valley. Initially, logs were obtained directly from the CA DOGGR district office in Santa Maria, Calif., by physically scanning paper copies of the electric logs. The CA DOGGR has subsequently made some of the electric logs available on-line (http://owr.conservation.ca.gov/ WellSearch/WellSearch.aspx).

In the 1980s four masters theses (Nevins, 1982; Schwing, 1984; Calhoun, 1986; Spitz, 1986) and one Ph.D. dissertation (Ellis, 1994) were produced at Oregon State University under the guidance of Professor Robert Yeats. These works, and related publications (Schwing, 1982; Ellis and Spitz, 1987; Yeats and others, 1989), discussed the subsurface geology of Cuyama Valley and focused on the mapping of subsurface formations by using data from oil exploration holes, in particular electric logs. Each thesis contained several stratigraphic cross sections that correlated subsurface formations across the 
valley (Sweetkind and others, 2013). Although the focus was primarily on the Miocene section, the cross sections showed the interpreted base of the Morales Formation and, occasionally, showed correlation of distinctive marker units within the Morales. These sections served as a starting point for the electric log interpretations of formation tops in this study.

\section{Water Wells}

Downhole lithologic data from water-well drillers' logs, used here to interpret formation tops and sediment grain size and sorting parameters, were derived from three sources: a U.S. Geological Survey Water-Supply paper on Cuyama Valley (Upson and Worts, 1951), lithologic data associated with well records obtained from the USGS National Water Information System (NWIS), and well data obtained from the State of California Department of Water Resources (CA DWR). Lithologic data from all wells reported by Upson and Worts (1951) were transcribed from the paper report. The location map that accompanied that report was georeferenced in a GIS, and well locations were digitized. Lithologic data associated with NWIS records and from CA DWR were also transcribed and tied to reported site locations. CA DWR wells were located according to descriptive information included on the well completion reports submitted to the State of California. The specific location of each well differed from GPS locations recently confirmed in the field with differential GPS systems to sketched maps or township, range, section, and quarter-quarter-section information on the well completion reports. Wells that had sufficiently detailed sketch maps were assigned a latitude-longitude by comparing the sketch maps with georeferenced aerial photos in a GIS. Latitude-longitude locations were established for wells listing only the township, range, section and quarter-quarter section locations on the drillers' logs by calculating the center position of the most detailed part of the township and range location. Ultimately, all well locations were cross-checked against locations in the NWIS database, with well compilations for hydrologic data compiled for Cuyama Valley (Everett and others, 2013) and with field-checked locations.

Of the water wells compiled for stratigraphic information, 21 were from Upson and Worts (1951), and 56 wells came from the State of California and other sources. Of the water wells compiled for lithologic information and subsequent textural analysis, 41 were from Upson and Worts (1951), and 110 wells were from the State of California and other sources.

\section{Interpretation of Subsurface Data}

Stratigraphic contacts, including the top of Qoa and the top and base of the QTm were interpreted from electric logs and drillers' lithologic logs. For the oil and gas wells, formation tops were almost invariably interpreted from electric logs. Lithologic logs from the oil and gas exploration holes were not helpful in the shallow alluvial section, which was not of interest to the well-site geologists. Lithology in the shallow parts of these holes was typically logged with a single descriptor, such as "sand and gravel," that might apply to hundreds of meters of section. Similarly, the tops of Qoa and the QTm were typically not recorded by these geologists; formation tops were reported only for consolidated rocks below the Morales Formation. In contrast to the oil and gas exploration wells, very few water wells had electric logs. Stratigraphic tops generally were interpreted in the water wells from drillers' lithologic descriptions.

\section{Oil and Gas Wells}

An electric log typically consists of a spontaneous potential, or SP, curve placed alongside one or more resistivity curves (fig. 5). Many of the oil and gas exploration wells in Cuyama Valley were drilled in the 1940s and 1950s (Stanley, 1995), when these particular logs were commonly the only geophysical logs run. They are valuable for correlating geologic units between wells, determining unit or bed thickness, distinguishing porous and non-porous rocks in shale-sandstone sequences, and identifying beds containing fresh water (Keys and MacCary, 1971).

Stratigraphic units, and lithologic variations within stratigraphic units, are interpreted on the basis of their characteristic electric log response (Keys and MacCary, 1971; Johnson and Pile, 2002); interpretations are tied, where possible, to lithologic descriptions of cuttings and core and to nearby outcrops. High-porosity quartz-bearing units, such as sandstone and sand and gravel, typically show leftward deflections of the SP-curve (toward more negative values) and rightward deflections of the resistivity curves (toward larger resistivity values). Low-porosity, shaly units tend to have the opposite electric $\log$ response, with rightward deflections of the SP-curve (toward more positive values) and leftward deflections of the resistivity curves (toward smaller resistivity values; Keys and MacCary, 1971; Johnson and Pile, 2002). In thin-bedded units, the poor vertical resolution of the SP-logging tool produces an average log response from multiple lithologic units rather than separating the units. Because SP- and resistivity logs measure a response only where the borehole contains fluids - either drilling mud or formation waters - the upper few hundred feet of section potentially would not be captured by these methods (fig. 5), and, in certain wells, the shallowest stratigraphic units were not recorded by the electric logs.

Qya has generally high, but irregular, resistivity values characterized by high amplitude, short wavelength, resistivity peaks (fig. 5). This response is a result of large clast size, poor sorting, and abundant channel deposits of gravelly material inset into finer-grained overbank deposits that create abrupt lithologic contrasts and generate a strong resistivity-log response. The subdued nature of the SP-log response could be the result of thin bedding.

Qoa tends to have a more subdued resistivity-log response when compared to Qya (fig. 5), although some wells have resistivity peaks of moderately-high amplitude and short wavelength when compared to the underlying section. The contact with the underlying Morales Formation is typically 


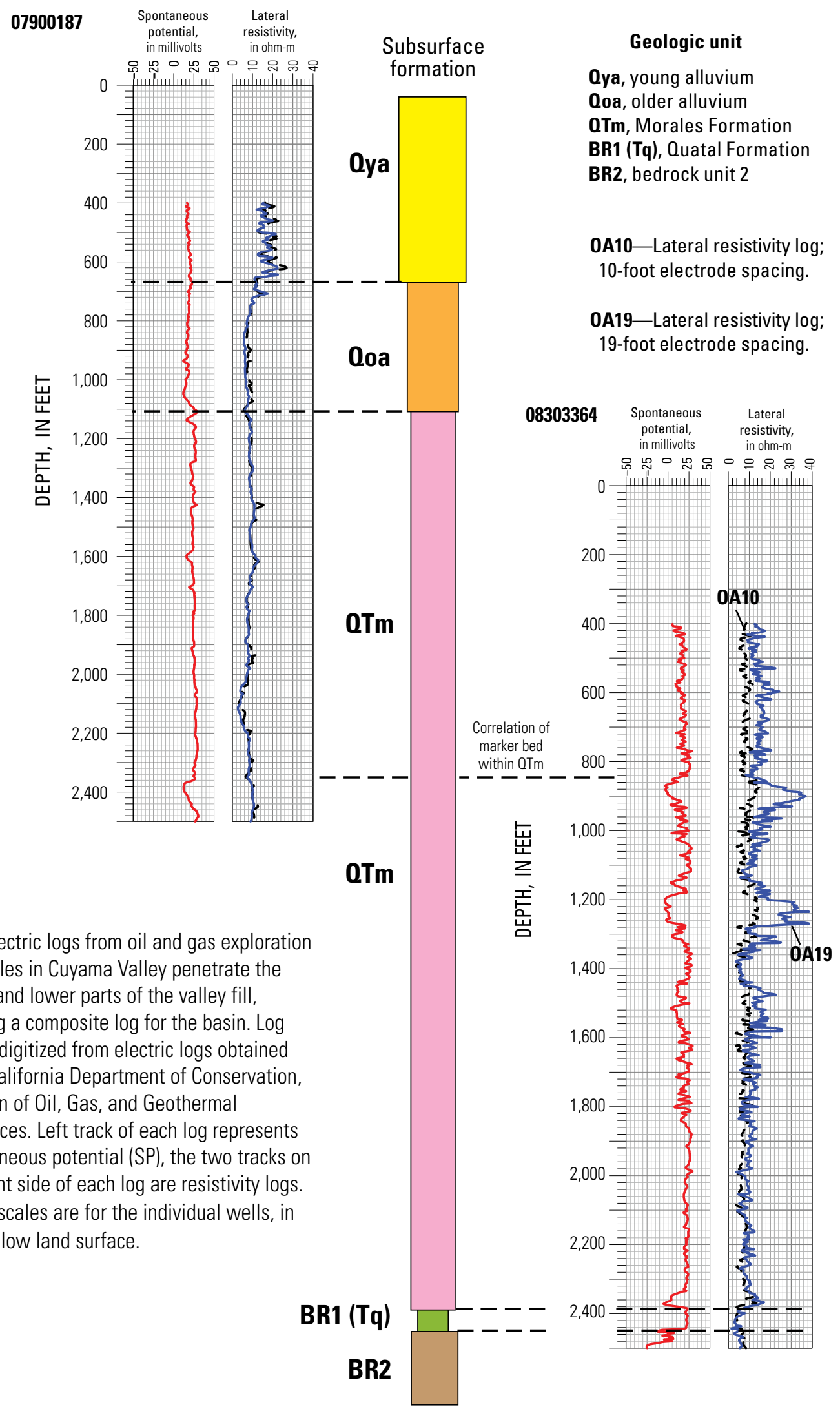

Figure 5. Composite electric log from the Cuyama Valley study area. 
marked by a thin zone with inward deflections of the SP-curve (rightward, toward more positive values) and the resistivity curves (leftward, toward smaller resistivity values) (fig. 5; 1,100-ft depth, $\log 07900187$ ).

The QTm can be broadly subdivided into an upper part that has a generally subdued electric log response in both the SP- and resistivity curves (fig. 5; between 1,100 and 2,350-ft depth, $\log 07900187$ ) and a lower part that has several distinct coarse-grained intervals (fig. 5, log 08303364). In outcrop, this upper unit is poorly-sorted, consisting of pebbles and cobbles in a fine sand matrix (Dibblee and Minch, 2005a, 2006; Kellogg and others, 2008). The subdued log response in the upper part of the QTm could be the result of the lack of distinct bedding and lithologic contrast between beds of differing grain size. In this interval, the Morales Formation tends to be a massively-bedded arkosic clayey sandstone derived from granitic and metamorphic rocks (Hill and others, 1958). In the lower part of the QTm, boulder trains and gravelly channel deposits create deflections to lower values on both SP- and resistivity logs (fig. 5, log 08303364). The Quatal Formation (Tq, fig. 5, $\log 08303364$ ) below the QTm is picked as a distinctive interval characterized by inward deflection of both the SP- and resistivity curves.

Ideally, an oil and gas exploration well would intersect a partial thickness of Qya and the full thickness of Qoa and the QTm (fig. 5). As a result of the variable stratigraphic and structural setting across the basin, few individual wells encounter all of these stratigraphic units (fig. 6). Exploration wells drilled in upland areas to the south of the valley are spudded in Qoa, such that only the top and base of the QTm are intersected. In some cases, the electric logging begins below the top of the QTm, such that only the base of the unit is recorded (fig. 6). Previous workers (Nevins, 1982; Schwing, 1984; Calhoun, 1986; Spitz, 1986), who interpreted electric-log data in Cuyama Valley, tended not to pick the top of the Morales Formation but, instead, identified distinctive marker beds within the Morales Formation that allowed correlation between wells in the upper part of the sedimentary section (fig. 6). The most readily identifiable horizons within the Morales Formation are distinctive fine-grained units that represent periods of depositional quiescence across parts of the basin. Similarly, coarse sand bodies can be correlated over more limited areas, but the fine-grained units tend to be more widely distributed and can be correlated over broad areas (fig. 6). These fine-grained units serve as stratigraphic marker horizons within the Morales Formation and serve as guides to the relative elevations of the top and base of the formation in any borehole.

\section{Water Wells}

Water well drillers' lithologic descriptions were highly variable in terms of the number and thickness of subsurface intervals described, the detail of the descriptions, and the words used to describe specific sediment types and textures. The descriptions required geologic interpretation to obtain consistency between wells and to identify the unit penetrated.
Key descriptive elements used to identify stratigraphic units included the degree of cementation and relative amount of clay; color was considered a secondary element, but was not used as a primary discriminator. Degree of cementation was used to distinguish Qoa from Qya where, in many cases, deeper intervals encountered during drilling would be described as "hard" or "slow drilling," or the intervals would be described as sandstone and conglomerate, instead of sand and gravel, respectively. The Morales Formation was often distinguished from the overlying older alluvium by an abrupt increase in the number of clayey intervals. The clayey, arkosic sands of the Morale Formation were often described by drillers as "decomposed granite," in contrast to overlying intervals described as sand and gravel. Thin intervals described as being yellow, orange, or red in color, where present within a thick interval described by another color, were interpreted as possible paleosols that record an episode of exposure and surficial weathering. These intervals were interpreted as boundaries between units where supported by other factors, such as degree of cementation.

\section{Compilation of Stratigraphic Tops from Well Data}

Stratigraphic tops from the oil and gas and water wells were assembled in a single database and checked for internal consistency. The spatial distribution of these tops is shown in a perspective view looking from above and north to the south in figure 7. In this view, water wells appear as a cluster of relatively shallow wells along the center of the basin that mostly intercept the Qya. Oil and gas exploration wells predominantly intercept the Qoa and QTm units. Wells in the far southeast part of the study area (upper left part of figure 7) penetrate thin sections of younger alluvium overlying bedrock units. Stratigraphy was not interpreted for every downhole interval in every well. Where stratigraphic units were not interpreted for specific downhole intervals, they are shown as a thin vertical line (fig. 7).

Contacts interpreted from borehole lithologic and electric logs were assigned $\mathrm{x}, \mathrm{y}$, and $\mathrm{z}$ coordinate locations for use in the geologic framework model. All boreholes were assumed to be vertical, so that all contacts from a well were assigned the $x, y$ coordinates of the well's surface location. Stratigraphic unit contacts, originally compiled as depth below land surface from the source data, were converted to elevation values by subtracting measured depth from the land-surface altitude at the well. Two types of data were generated from the borehole records: points where the stratigraphic top was explicitly picked from the data and points that only define limiting values for the elevation of the top. Limiting values are defined for cases where the top of the formation is above the start of the electrical geophysical log, such that the top of the log only provides a maximum value for the drilled depth to the top of the stratigraphic unit. 


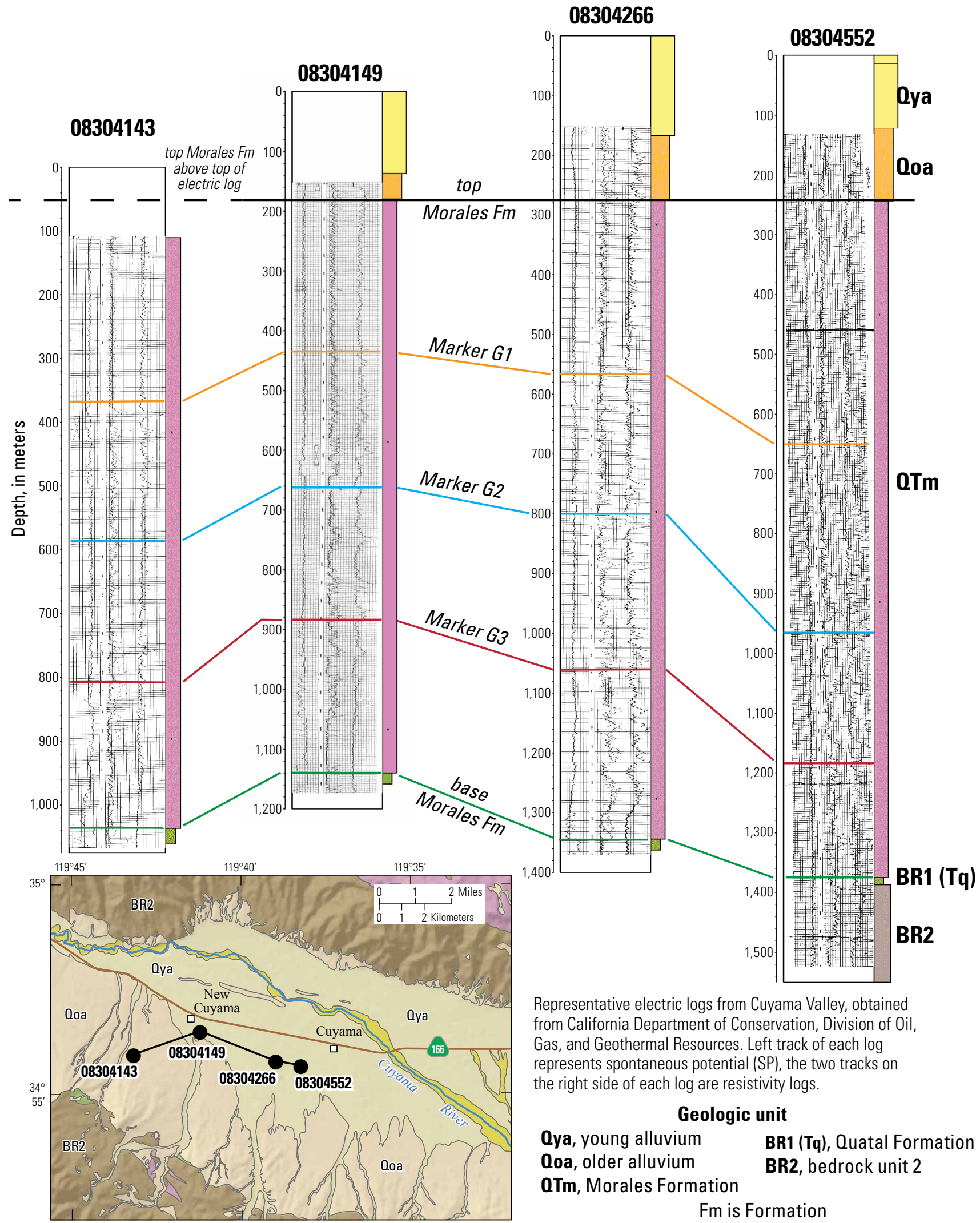

Figure 6. Correlation of electric logs from the central part of the Cuyama Valley study area. 


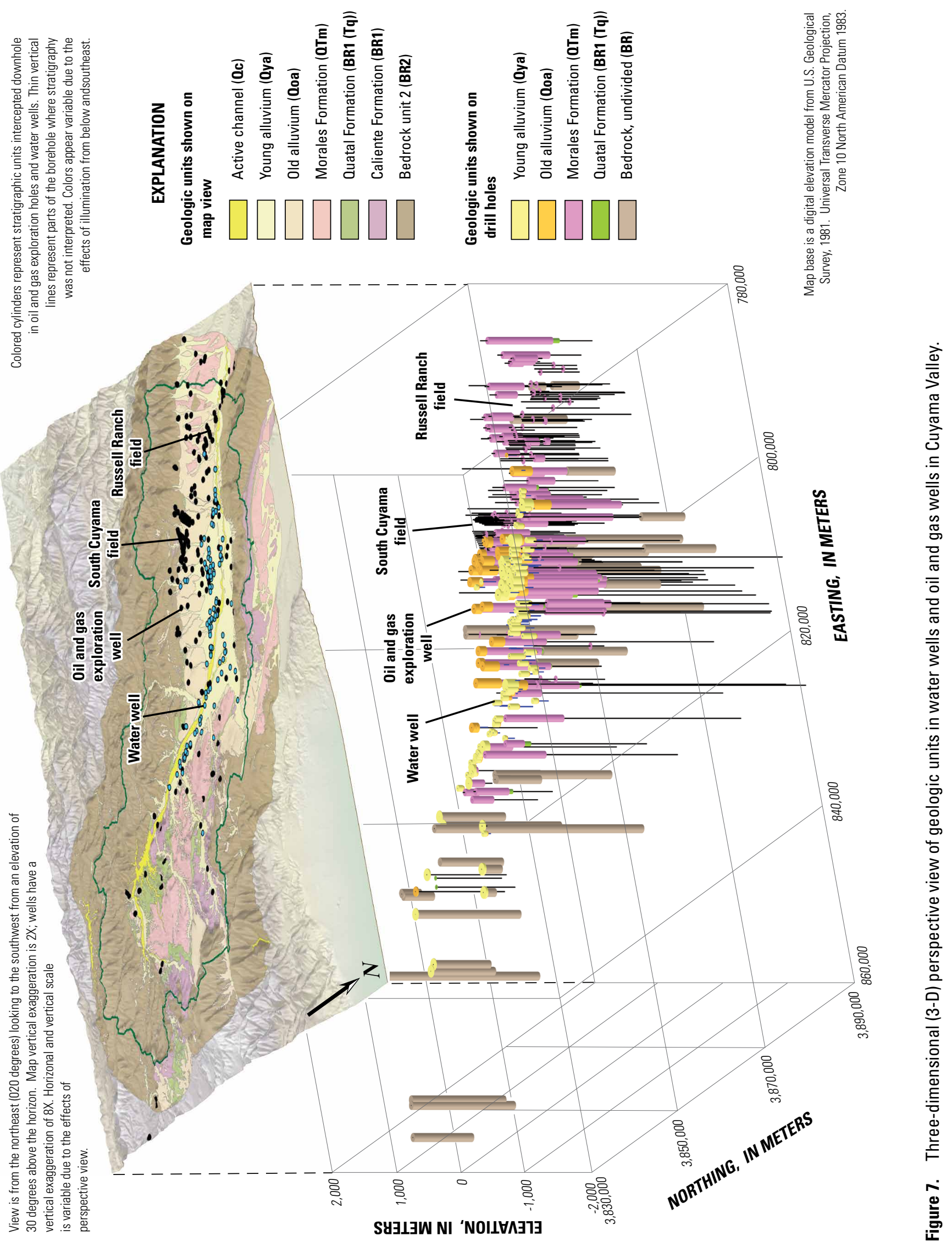




\section{3-D Geologic Framework Model}

A 3-D geologic framework model was constructed to represent the subsurface geometry of the stratigraphic units, Qya, Qoa, QTm, and a composite pre-QTm bedrock unit. This digital model provides the fundamental geologic framework for the subsequent development of a transient numerical hydrologic-flow model of the study area (Randall Hanson, U.S. Geological Survey, written commun., 2013).

The geologic framework model was constructed by creating surfaces representing the altitude of the top of each stratigraphic unit from the input data and then combining these surfaces within a 3-D geologic modeling software package. Each surface is represented by a grid covering a rectangular area slightly larger than that shown in figure 2 , with dimensions of $85,000 \mathrm{~m}$ in the east-west direction and $65,000 \mathrm{~m}$ in the north-south direction. Square grid cells are $200 \mathrm{~m}$ in size, resulting in 426 grid cells in the east-west direction and 326 cells in the north-south direction. Software-based requirements for the grids and 3-D model to be aligned with the cardinal directions resulted in the inclusion of areas to the northeast and southwest of Cuyama Valley far outside the area of interest to this study.

To construct the geologic framework model, spatial data, such as digital elevation, outcrop, and borehole information, were compiled using Environmental Science Research Institute (ESRI) ArcGIS ${ }^{\circledR}$ software. Interpolation of spatial data points into grids representing the stratigraphic unit tops was processed using Rockware Rockworks14® 3-D-modeling software. This software was designed to represent stratigraphic relations within sedimentary basins, including representation of depositional contacts and stratigraphic onlap, erosion, and unconformities. The 3-D-modeling software does not allow explicit entry of fault surfaces into the 3-D framework, so the effect of faulting was accomplished by inserting numerical discontinuities during the gridding of individual horizons. The resultant grids have steep inflections at the fault trace but remain as continuous surfaces within the geologic framework model.

\section{Modeling Approach}

The geologic framework model represents the altitude of the top of stratigraphic unit as a grid that spans the entire rectangular framework model domain. Because of the requirement for grids to be continuous, where stratigraphically lower units are exposed at land surface, one or more shallower units are required to have the same land-surface elevation but to have zero thickness (fig. 8). Four general cases describe the elevation and thickness of a particular stratigraphic horizon with respect to the elevations of other horizons in the geologic framework model (fig. 8):

(1) The top of the unit is present in the subsurface beneath other units, where the elevation of the unit top is defined by well data or by the thickness of the overlying unit and the thickness of the unit is defined by well data.

(2) The unit crops out at land surface, such that the eroded top of the unit is defined by the DEM, and the thickness of the unit is defined by well data.

(3) The unit of interest has an elevation defined by the DEM and zero thickness where an underlying unit crops out at the surface.

(4) The unit of interest can crop out at land surface, where the elevation of the top is defined by the DEM, or exist in the subsurface, where the elevation of the top is defined by well data, but thickness of the unit is an arbitrary or assigned value.

As an example, figure 9 depicts these general cases as they were applied to Qoa over the western half of the study area. In the center of the basin (region 1, fig. 9), Qoa is overlain by Qya, and the elevation of the top of Qoa is defined by well data. Where Qoa crops out at land surface (region 2, fig. 9), the top of the unit is defined by the DEM, and the thickness of the unit is defined by well data. The top of the unit in this case is a modeled top based on erosion at land surface, not the true stratigraphic top. In a relatively small area on the extreme eastern edge of the study area (region 3, fig. 9), map data and limited well data indicated the presence of Qoa, but the well data were too limited to create a satisfactory thickness grid, and the unit was assigned an arbitrary thickness (region 3, fig. 9). Finally, in areas of bedrock outcrop (region 4, fig. 9), the top of Qoa is assigned the elevation of land surface and a thickness of zero. Using the cases described above, the elevation grids for each stratigraphic unit were built in an iterative fashion. First, the parts of the unit present in the subsurface were gridded using the well data. These grids were then modified in areas where the unit cropped out or where underlying units were exposed at land surface.

Input data points were pre-processed with a declustering routine prior to surface gridding, such that multiple closelyspaced data points were assigned an averaged location and altitude value that was used as input to the surface-modeling routine. The optimal degree of pre-processing was one that eliminated extreme clusters of data (for example data from closely-spaced production wells in oil fields), but did not result in an overly smoothed trend where all local variation was eliminated. Data representing the altitude of a stratigraphic top were gridded using an inverse distance algorithm, where 
the value assigned to a grid node was computed as a distanceweighted average of the nearest 12 directionally-distributed neighbors. The value of each of the data points was exponentially weighted according to the inverse of its distance from the grid node; weighting was adjusted to balance the effects of strong, local control with a broader regional average.

For computational convenience, all faults in the study area were generalized as vertical boundaries and dropped from their surface locations. Faults were inserted within the gridding algorithm as two-dimensional (2-D) boundaries that acted as a barrier to information flow during horizon gridding. When point data were gridded, elevation data on one side of a fault were not directly used when calculating grid node values on the other side of the fault. The resultant grids have sharp inflections where the altitude of the surface changes rapidly, but the gridded surface remains continuous and is not split into two segments by the fault.

For the purposes of use within a numerical hydrologic-flow model, the faults were classified according to their recency and the stratigraphic units that each fault offsets (table 2). Motion on the Russell fault is documented to have ended during Morales Formation time, and the fault does not affect younger units (Yeats and others, 1989; Ellis and others, 1993). Well data indicated that the Morales and Santa Barbara Canyon faults create offset in the Morales Formation and the older alluvium (table 4). The thrust faults that bound the Turkey Trap Ridge and Graveyard Ridges (fig. 4) affect all stratigraphic units within the basin, as does the Rehoboth fault (fig. 4, table 2).

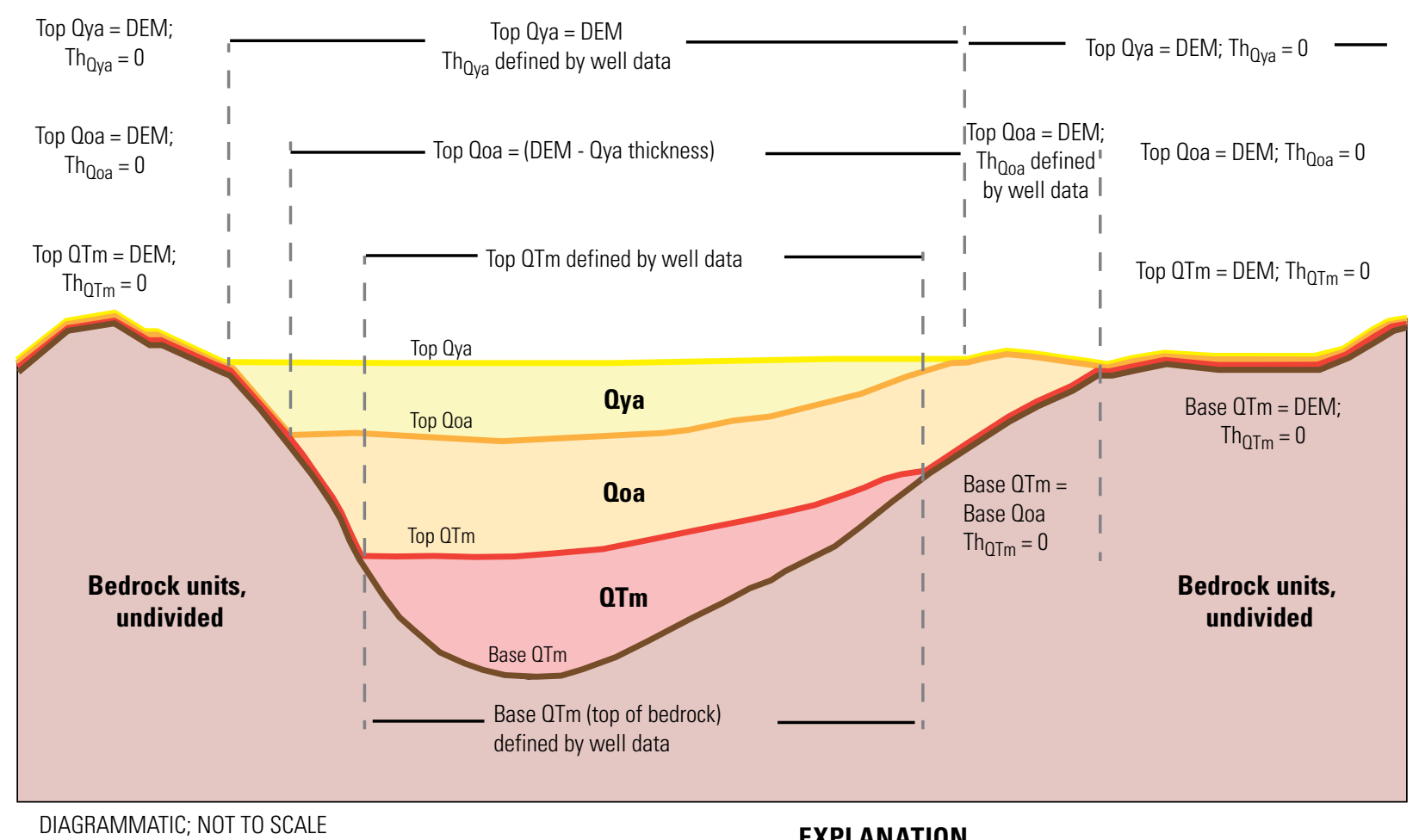

DIAGRAMMATIC; NOT TO SCALE

EXPLANATION

Top Oya, elevation of the top of unit Oya

Top Qoa, elevation of the top of unit Qoa

Top QTm, elevation of the top of unit QTm

Base QTm, elevation of the base of unit QTm

(= elevation of top of bedrock)

\section{Geologic unit}

Oya, young alluvium

Qoa, older alluvium

QTm, Morales Formation

$$
\begin{aligned}
& \text { Th Oya }, \text { thickness of unit Qya } \\
& T_{0 o a} \text {, thickness of unit Qoa } \\
& T_{0 T m} \text {, thickness of unit OTm }
\end{aligned}
$$

DEM, Digital elevation model

Figure 8. Diagrammatic cross section showing relative elevation of stratigraphic unit tops and resultant thickness within the framework model. 


\section{Construction of Gridded Surfaces}

Gridded surfaces were interpolated from the data described in the previous sections. The approach for gridding the Qya and Qoa surfaces differed from that used for the QTm and bedrock surfaces as a result of differences and limitations of the data. The strategy for contouring each stratigraphic unit is presented in this section, and the final top altitude grids are presented.

\section{Younger Allvium, 0ya}

As the stratigraphically highest unit, the top of Qya is everywhere defined by the digital elevation model; the areal
Table 2. Geologic units affected by Cuyama Valley faults.

[Qya, Younger alluvium; Qoa, Older alluvium; QTm, Morales formation]

\begin{tabular}{lc}
\hline \multicolumn{1}{c}{ Fault name } & Affected Geologic Units \\
\hline Whiterock fault & QTm only \\
Russell fault & QTm only \\
South Cuyama fault & QTm only \\
Morales fault & Qoa and QTm \\
Santa Barbara Canyon fault & Qoa and QTm \\
Graveyard Ridge fault & Qya, Qoa, and QTm \\
Turkey Trap Ridge fault & Qya, Qoa, and QTm \\
Rehoboth fault & Qya, Qoa, and QTm \\
\hline
\end{tabular}

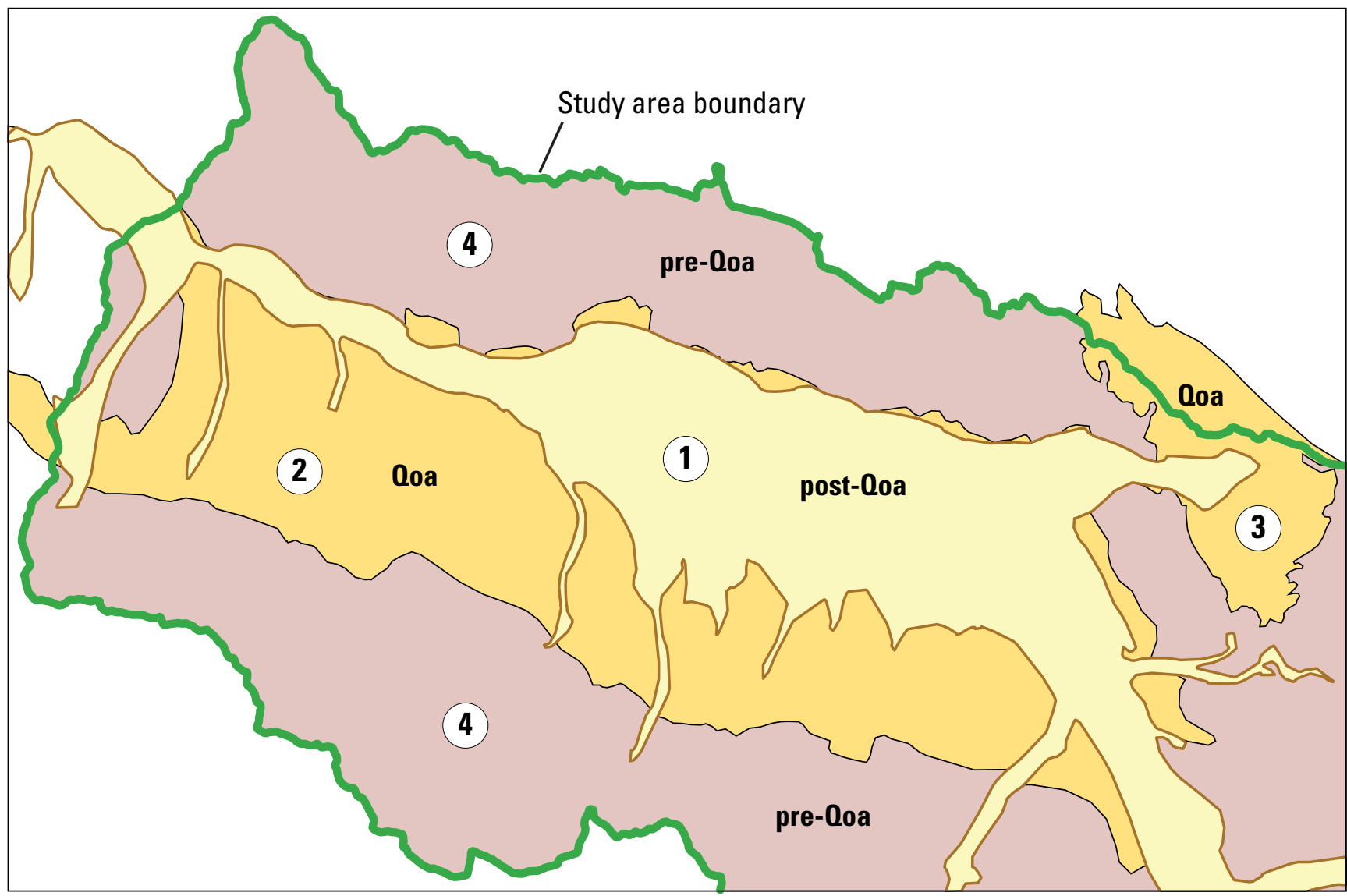

Diagrammatic; not to scale

\section{Geologic unit}

Qc, alluvial channel Oya, young alluvium Qoa, older alluvium QTm, Morales Formation BR1, Bedrock unit 1 BR2, Bedrock unit 2

\section{Stratigraphic unit}

post-0oa, outcrop of units above Qoa (Oc and Qya)

Qoa, outcrop of Qoa

pre-0oa, outcrop of units below Qoa (OTm, BR1, and BR2)

\section{EXPLANATION}

Definition of unit elevation and thickness

1 Elevation of top of Qoa defined by thickness of Qya

2 Elevation of top of Qoa defined by DEM, thickness defined by well data

(3) Elevation of top of Qoa defined by DEM, thickness defined arbitrarily at $175 \mathrm{~m}$

4 Elevation of top of Qoa defined by DEM, thickness is zero

Figure 9. Conceptualization of the elevation and thickness of unit Qoa within the geologic framework model for the western part of the study area. 
extent of the unit is defined by the geologic map (fig. 4). In parts of the framework model area, for example in the upstream reach of the Cuyama River, Qya is unconformable on and incises into older units. Accurate portrayal of these stratigraphic relations is aided by the construction of a thickness map for Qya that can then be superimposed upon the older units within the framework model.

A map of the total areal extent of Qya was created by merging the mapped polygons of Qya and Qc in a GIS. Inside of the unit extent polygon, Qya thickness data from oil and gas wells and water wells (fig. 10) were contoured. In cases where a well bottomed within Qya, the thickness of Qya was constrained to be thicker than the total depth of the well at that location. This initial Qya thickness grid was hand-edited in alluvial channel areas that lacked well control as guided by thickness trends evident from well data along the main channel of the Cuyama River and its major tributaries. Qya thickness was assigned according to stream rank, such that the third-order stream of the Cuyama River channel was given the thickest sediments, second-order streams that were tributaries to the Cuyama River were given the next-greatest thickness, and first-order streams that were tributaries to the second-order streams were given the least thickness. The thickness grid was modified with the intent of connecting similar thickness values and creating smoothly-varying changes. The hand-edited grid was smoothed and then clipped with the unit extent boundary to create a final thickness map (fig. 10).

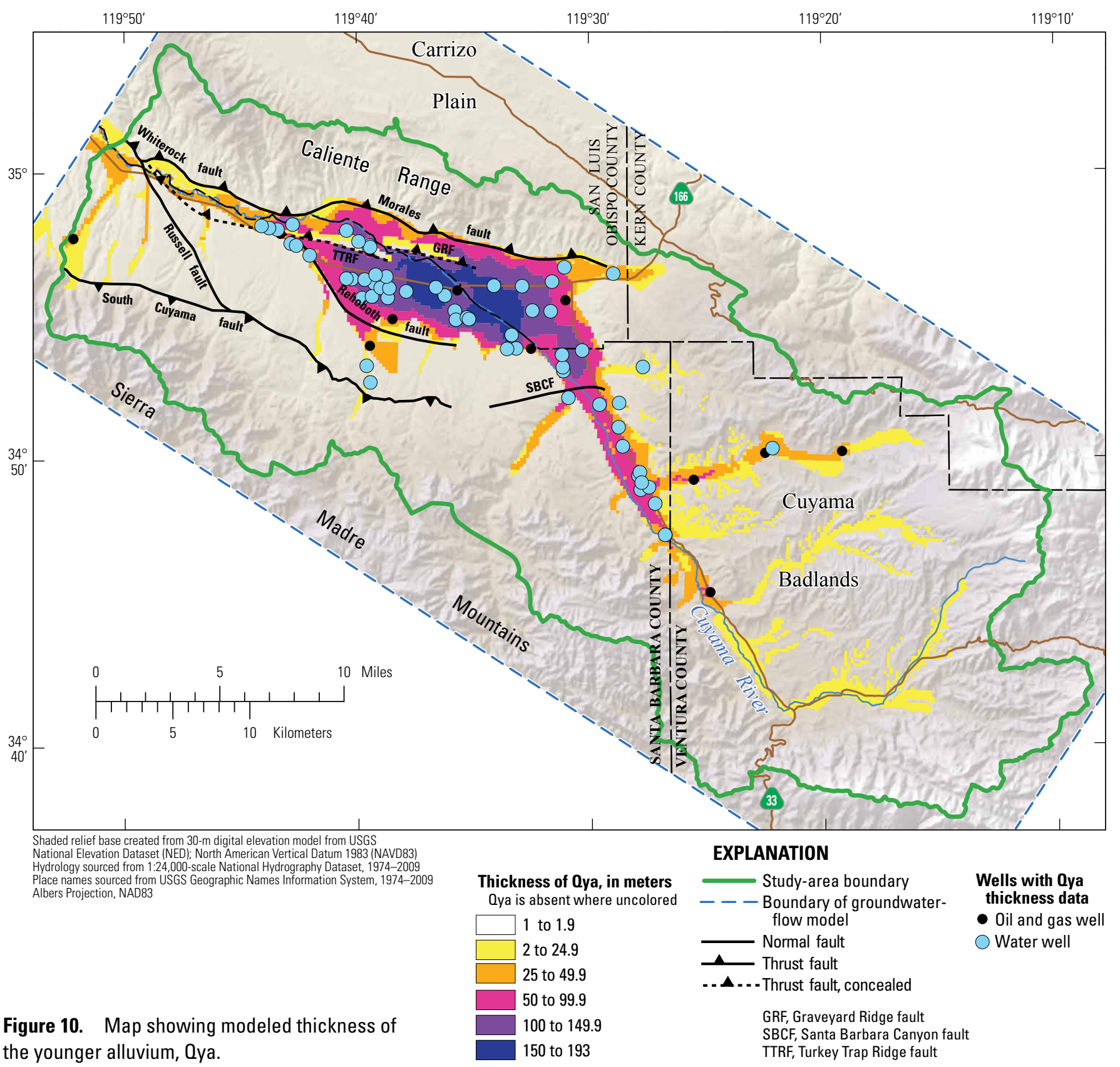




\section{Older Alluvium, Qoa}

The elevation of the top of Qoa is defined by the base of Qya, so that the thickness of Qya was subtracted from the digital elevation model to yield the top of Qoa (fig. 11). The top defines a west-northwest to east southeast trending trough that is aligned with axis of the valley, but skewed toward the north side of the basin against the base of the Caliente Range. This pattern is reflected by the surficial geology, where Qoa is uplifted and exposed along the south side of the basin as upland alluvial terraces (fig. 4), but buried by younger materials on the north side of the basin. Local linear troughs are present at alluvial channels draining the Sierra Madre Mountains, such as Santa Barbara Canyon and Salisbury Canyon (fig. 11), and result from incision of the older alluvium by young stream courses during recent uplift of the Sierra Madre Mountains (DeLong and others, 2008, 2011).

Qoa crops out where it is structurally uplifted by the Turkey Trap Ridge and Graveyard Ridge faults (fig. 11). To the south of these faults, well data showed that the top of Qoa is buried by as much as $200 \mathrm{~m}$ of Qya. The Rehoboth fault and Santa Barbara Canyon fault do not have a discernible effect on the elevation of Qoa at the scale at which Qoa is contoured (fig. 11).

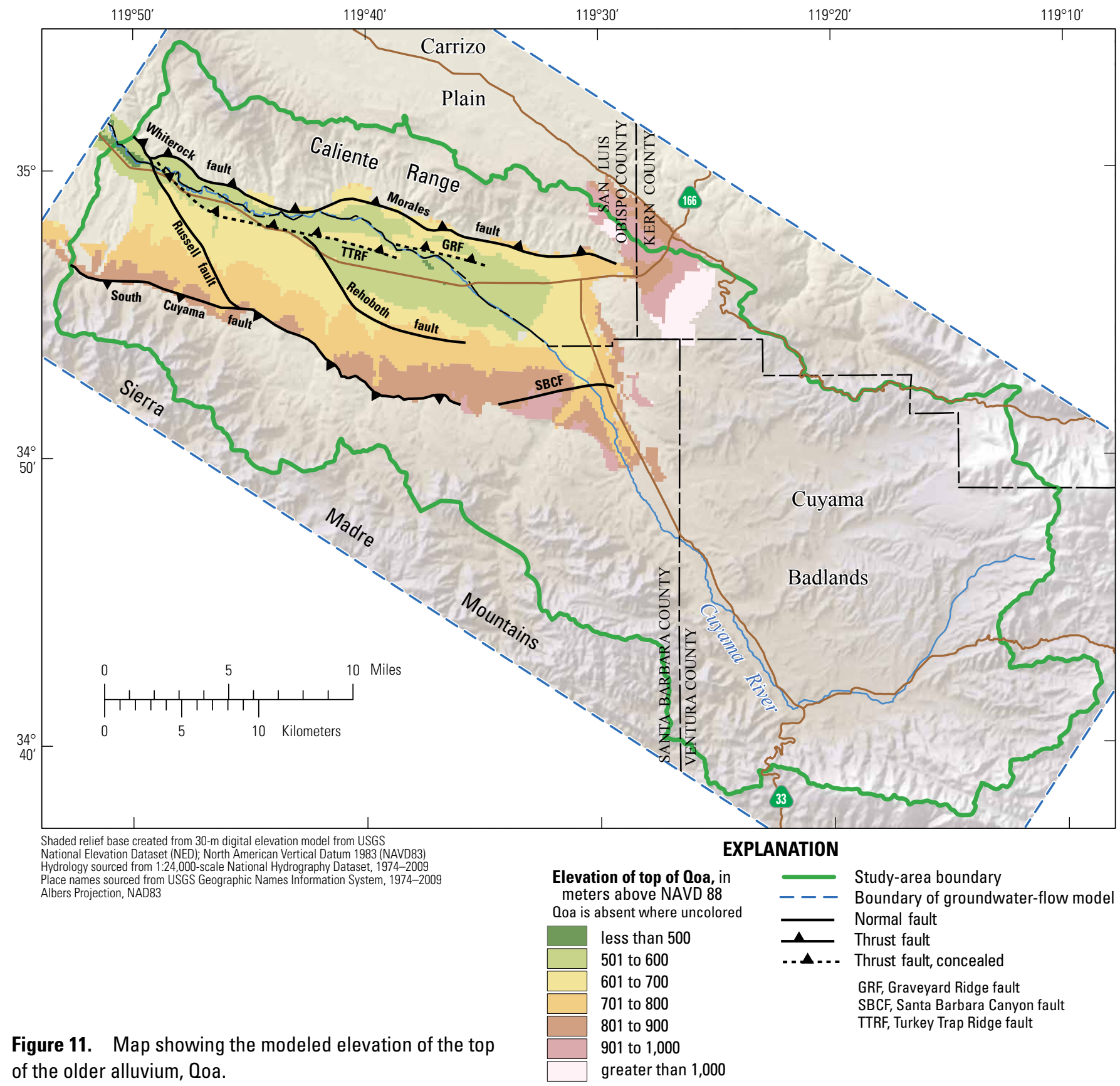




\section{Morales Formation, 0Tm}

Subsurface data for the QTm are clustered in the vicinity of the two producing oil and gas fields and are sparse in the southeastern part of the study area (black circles in fig. 12). A computer-contoured map of the top of the QTm, generated from only the well and outcrop data, produced unsatisfactory results that did not reflect the synclinal structure in the southeastern part of the study area. To improve horizon gridding, a generalized structural contour map of the top of the QTm was drawn by hand that honored the outcrop data and contact elevation from boreholes and that defined a broad, open syncline consistent with the map trace of the Cuyama syncline and with seismic reflection data (Ellis and Spitz, 1987; Ellis, 1994). Structure contours were converted to a series of regularly-spaced points, which were assigned coordinate locations and given the contoured elevation value (purple dots in fig. 12). These points became part of the input data for horizon gridding of the top of the QTm.

The top of the QTm generally defines an asymmetric westnorthwest to east southeast trending trough that is aligned with axis of the valley, such that the unit is deepest along the north side of the basin against the base of the Caliente Range and is shallowest along the south side of the valley (fig. 13). In

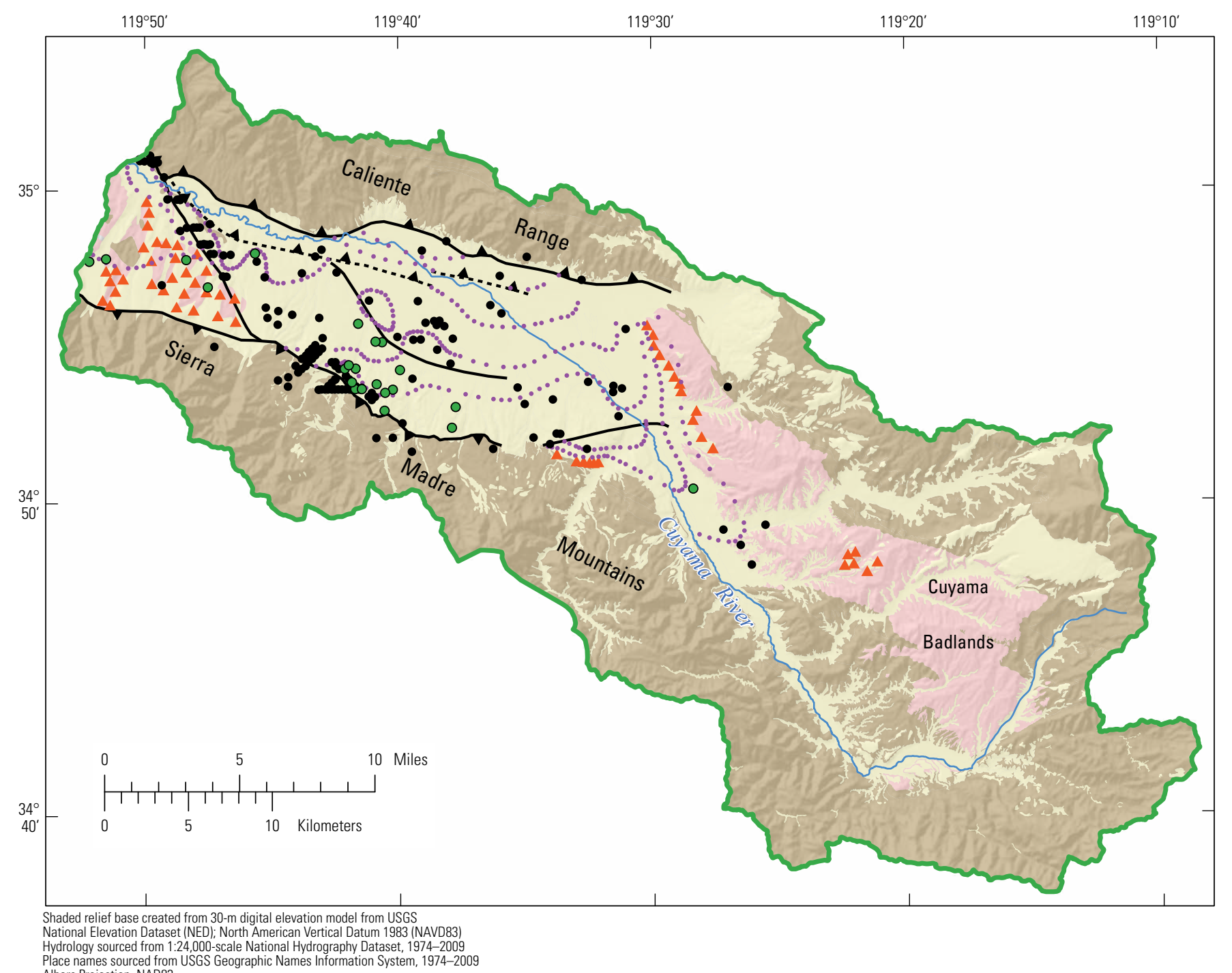

Place names sourced from USGS Geographic Names Information System, 1974-2009

Geologic unit

Qc, alluvial channel

Oya, young alluvium

Qoa, older alluvium

QTm, Morales Formation

BR1, bedrock unit 1

BR2, bedrock unit 2

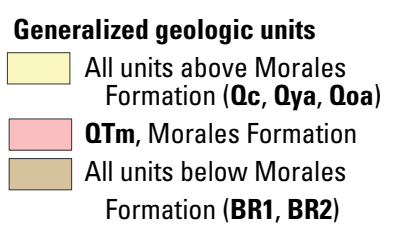

\section{EXPLANATION}

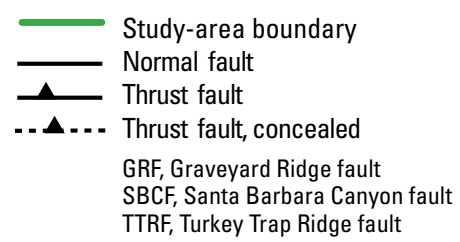

Geologic data used to map the top of QTm

$\triangle$ Mapped contact at surface

- Subsurface contact from well data

- Limiting value of contact elevation, from well data

- Unit base elevation defined by structure contour

Figure 12. Map showing geologic data used to map the top of the Morales Formation, QTm. 
the southeastern end of the valley, the trough trends parallel to the axis of the Cuyama syncline. The northwest-striking Russell and Rehoboth faults are both associated with relative highs in the top of the QTm (fig. 13). The unit is elevated on the southwest side of the Russell fault, whereas the Rehoboth fault roughly is centered on a structural high in the top of the QTm (fig. 13). The structurally elevated Morales Formation, next to the Russell and the Rehoboth faults, could be the result of transpression-related uplift as the tectonic regime changed from transcurrent to compressional faulting in the Pliocene. The small-offset Santa Barbara Canyon fault does not have a discernible effect on the elevation of the QTm at the scale at which the unit is contoured (fig. 13).

\section{Pre-Morales Formation (QTm) Bedrock}

Sparse well control on the elevation of pre-QTm bedrock was augmented by a generalized structural contour map of the base of the QTm that used the mapped trace of the Cuyama syncline to define the shape of the contour lines in the southeastern part of the study area (purple dots in fig. 14). Additional subsurface data (purple dots shown within thesis study areas, fig. 14) were obtained from detailed structure contour maps of the base of the QTm in the vicinity of the Russell Ranch oil field (Nevins, 1982) and the South Cuyama oil field (Schwing, 1984). Structure contours were converted to a series

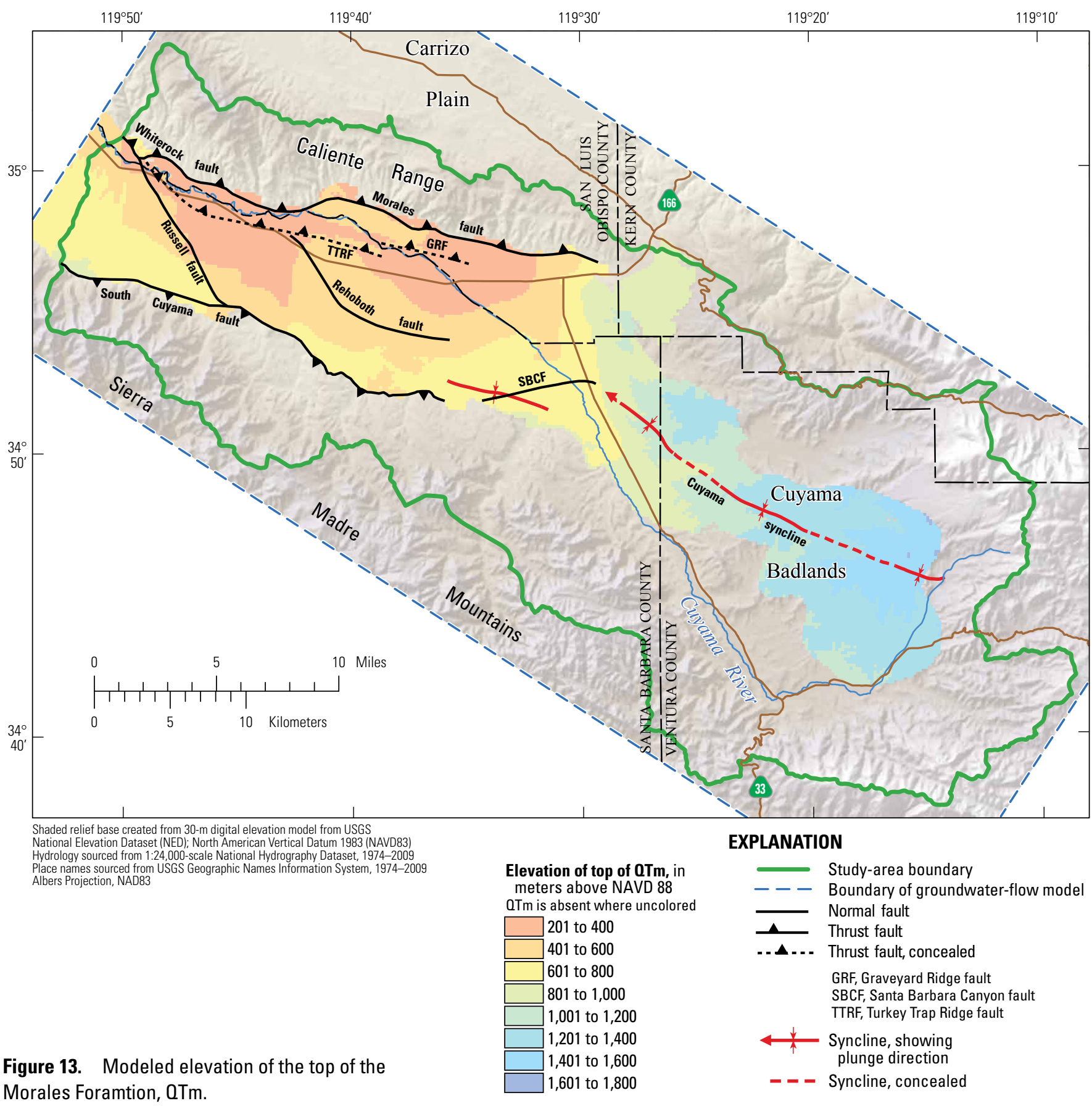


of regularly-spaced points that were assigned coordinate locations and given the contoured elevation value. These points became part of the input data for horizon gridding of the top of the pre-QTm bedrock (fig. 14).

The elevation of the top of the bedrock emphasizes the fault-bounded nature of the basin, where pre-QTm bedrock crops out to the north and south of the basin, but abruptly drops to great depths within the basin (fig. 15). The structural trough of the Cuyama syncline is evident in the eastern half of the basin and in the Cuyama Badlands (fig. 15). The Russell fault offsets the top of bedrock by as much as $500 \mathrm{~m}$ (Nevins, 1982). The Rehoboth and Santa Barbara Canyon faults do not disrupt the contoured elevation of the top of bedrock at the contouring interval shown on figure 15.

\section{3-D Geologic Framework Model Results}

The final 3-D-geologic framework was compiled with the Rockworks 3-D modeling package, which allows individual gridded surfaces to be stacked in stratigraphic order. Unit

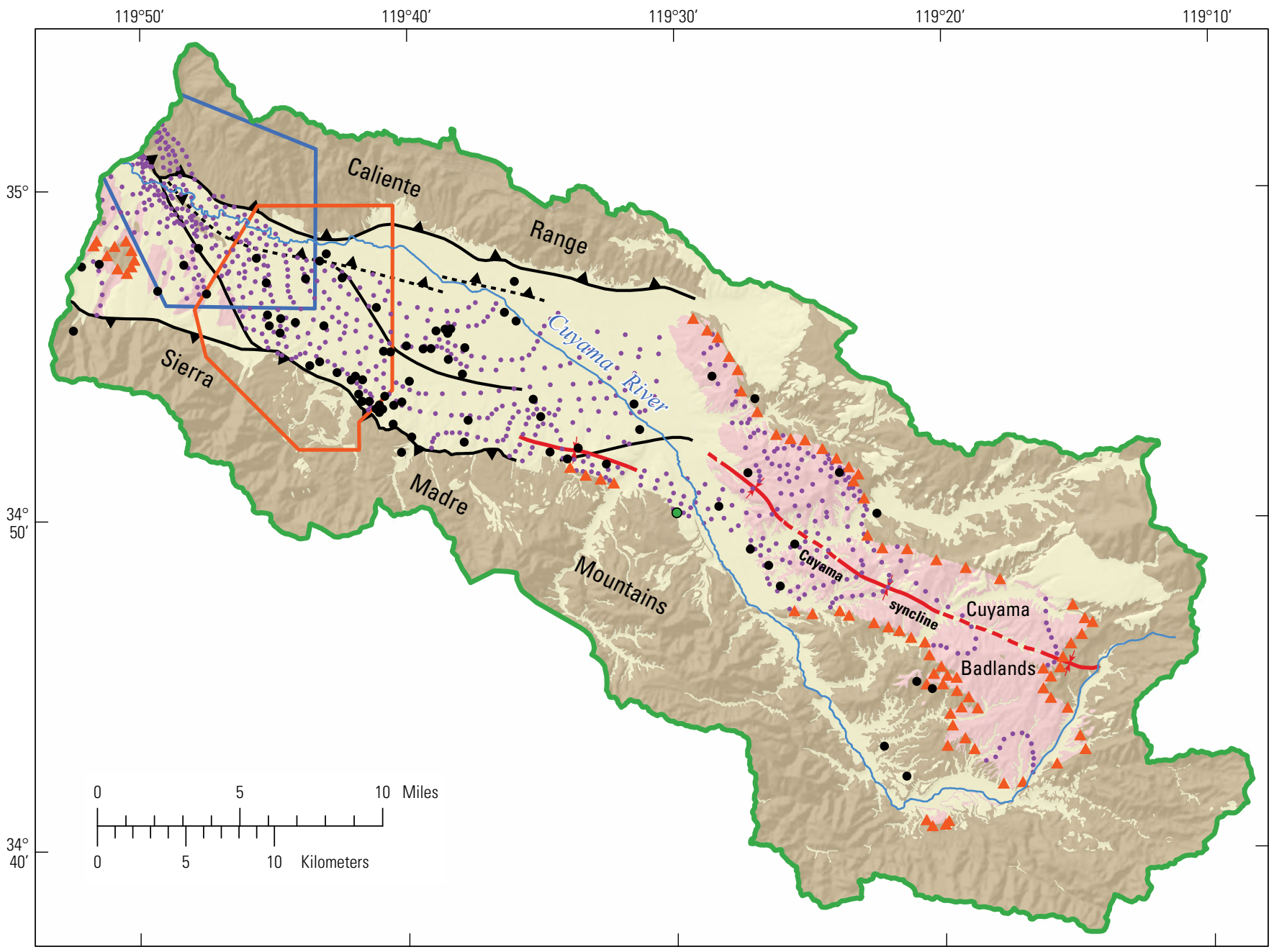

Shaded relief base created from 30-m digital elevation model from USGS National Elevation Dataset (NED); North American Vertical Datum 1983 (NAVD83) Hydrology sourced from 1:24,000-scale National Hydrography Dataset, 1974-2009 Place names sourced from USGS Geographic Names Information System, 1974-2009 Albers Projection, NAD83

\section{Geologic unit}

Qc, alluvial channel

Oya, young alluvium

Qoa, older alluvium

QTm, Morales Formation

BR1, bedrock unit 1

BR2, bedrock unit 2
Generalized geologic units All units above Morales Formation (Qc, Oya, 0oa)

OTm, Morales Formation

All units below Morales Formation (BR1, BR2)

\section{EXPLANATION}

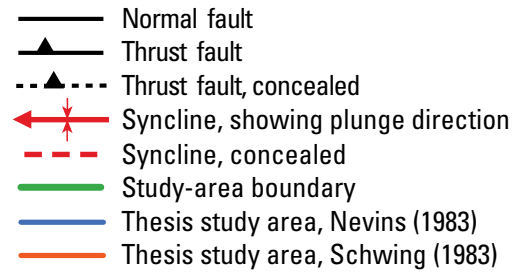

Geologic data used to map the top of pre-0Tm bedrock

- Mapped contact at surface

- Subsurface contact from well data

- Limiting value of contact elevation, from well data

- Unit base elevation defined by structure contour

Figure 14. Geologic data used to map the top of the pre-Morales Formation (OTm) bedrock. 
thickness is represented by the difference between altitudes of successive stratigraphic tops, such that the altitude of the base of a unit is always equal to the altitude of the top of the unit directly below it in the stacking order.

The results from the geologic framework model can be explored and visualized by slicing the model volume at any chosen location, as shown in a perspective view looking from above to the east (fig. 16). In the upper part of the figure, the

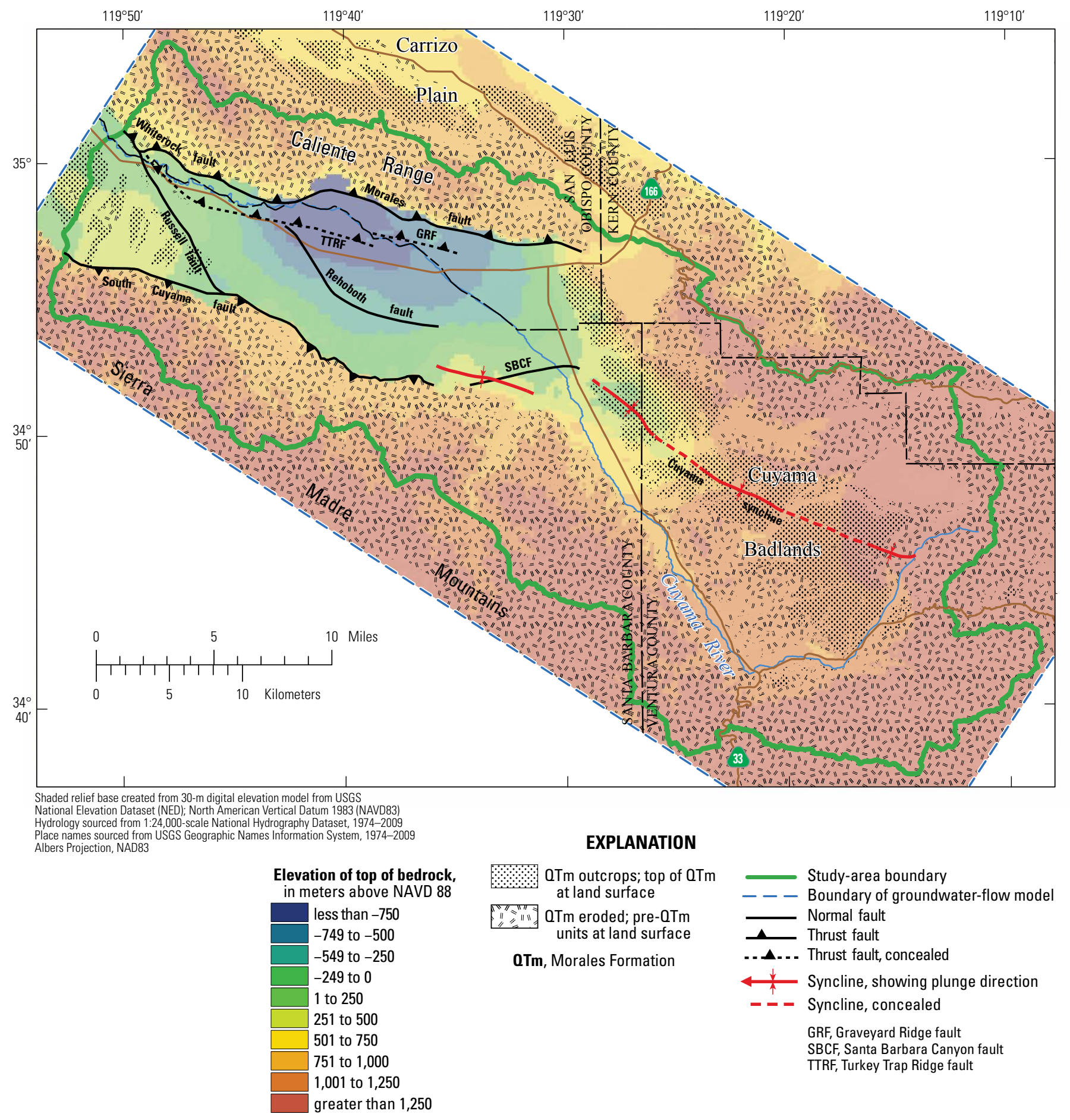

Figure 15. Modeled elevation of the top of bedrock. 
upper surface of the geologic framework is trimmed with a digital elevation model, creating a map of the geologic units predicted by the model to be present at land surface. The patterns of the geologic units at land surface are similar to the geologic map of the basin (fig. 4), providing a first-order check on the model's validity. In this view, extensive outcrops of the QTm are present in the Cuyama Badlands and at the western edge of Cuyama Valley; both areas match known surface exposures. Outcrops of Qoa are extensive along the south side of Cuyama Valley and are also present as uplifted blocks at the two fault-bounded ridges at the north side of the valley. The modeled extent of young alluvial Qya occupies the center of the valley and outlines the trace of the Cuyama River channel to the west of the Cuyama Badlands, following mapped surface outcrops.

View is from the west (280 degrees) looking to the east from an elevation of 20 degrees above the horizon. Upper figure has no vertical exaggeration; lower figure has a vertical exaggeration of $3 \mathrm{X}$. Horizonal and vertical scales are variable because of the effects of perspective view.

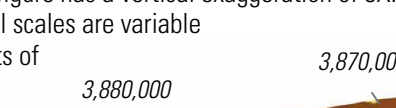

$3,880,000$

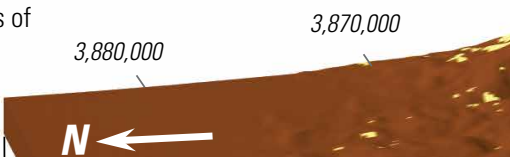

\section{NORTHING, IN METERS}

$3,850,000$
$3,860,000$
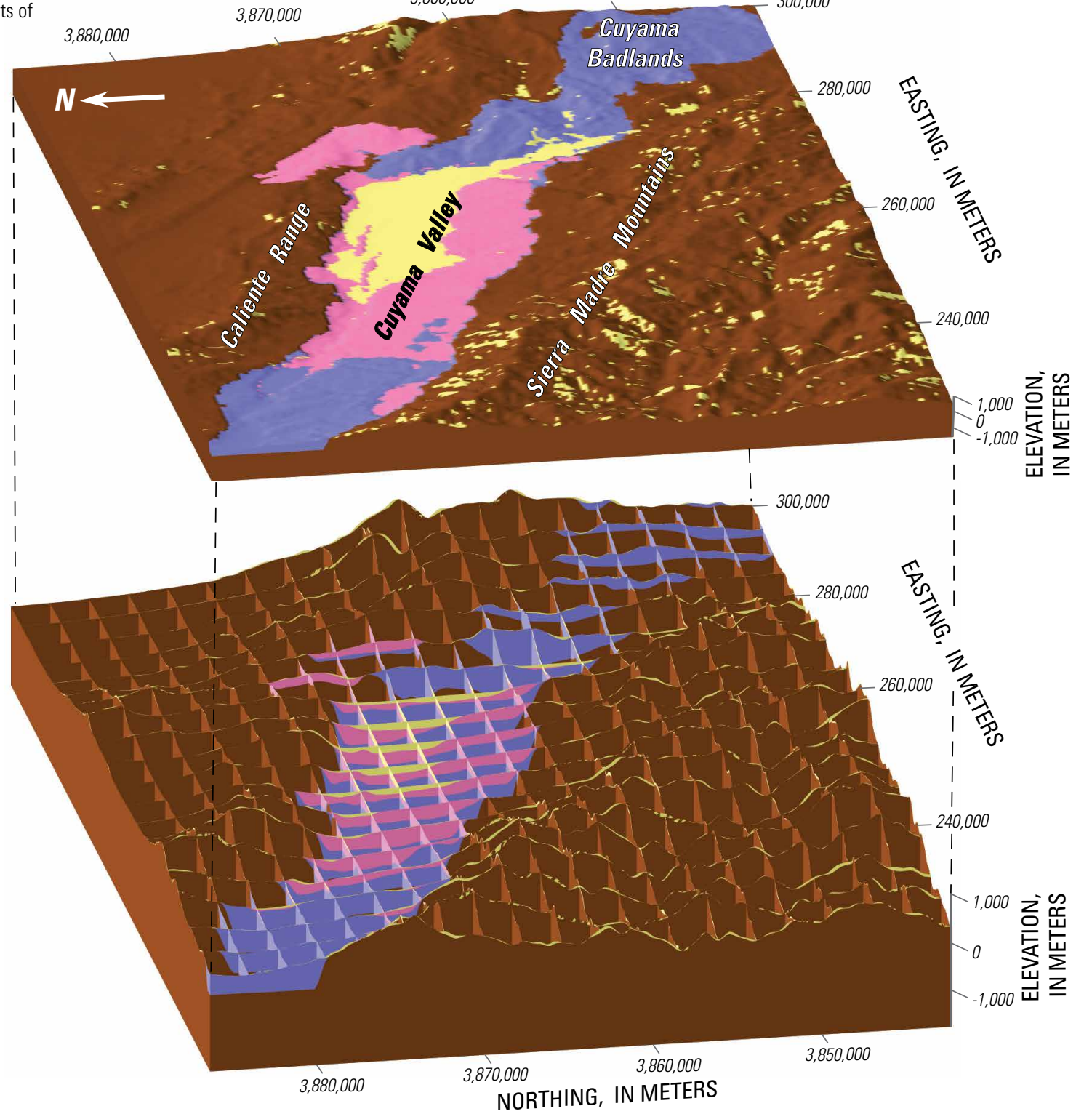

\section{EXPLANATION}

Colors appear variable because of the effects of lighting from the north

$\square$ Young alluvium (Qya) $\square$ Morales Formation (OTm)
$\square$ Old alluvium (0oa) $\square$ Bedrock, undivided

Upper figure shows the upper surface of the geologic framework model trimmed with a digitial elevation model, such that the upper surface of the geologic framework approximates a geologic map of the study area. The lower figure shows vertical sections that are cut through the geologic framework model in the north-south and east-west directions, showing the configuration of stratigraphic unit tops within the model volume.

Figure 16. Perspective views of vertical slices through the geologic framework model. 
The lower part of figure 16 shows a series of east-west and north-south vertical sections cut through the geologic framework model; these vertical sections allow for the visualization of the modeled stratigraphic unit tops beneath the valley. This figure shows the thickness of Qya in the axis of the valley, underlain by Qoa. The Qoa dominates the southern part of the valley, beneath its outcrop exposures, with the QTm underlying it. The QTm predominates in the Cuyama Badlands area, where it is essentially the only permeable stratigraphic unit, except for thin younger alluvium along the trace of the Cuyama River channel. The QTm is also exposed at the surface in the western part of the valley, where it is locally overlain by thin deposits of alluvium in the channel of the Cuyama River. The effect of fault offset is not obvious at the scale of figure 16, except for the appearance of Qoa at land surface at Graveyard Ridge and Turkey Trap Ridge (upper figure, fig. 16) and the abrupt change in elevation of Qoa beneath these ridges that can be identified in two vertical panels (lower figure, fig. 16).

Singer and Swarzenski (1970) published two cross sections showing the configuration of the water-bearing units in Cuyama Valley as interpreted from well control. One cross section was aligned roughly east-west $\left(A-A^{\prime}\right.$, fig. 4$)$, parallel to the trace of the interbasin thrust faults that bound the Turkey Trap Ridge and Graveyard Ridge, and a roughly north-south section was transverse to the major structural grain of the basin $\left(B-B^{\prime}\right.$, fig. 4). These sections were compared to the modeled elevation of the stratigraphic units from the geologic framework model along the same line of section (fig. 17).

The greatest difference between the previously published sections and the stratigraphic tops, as defined in the geologic framework model, is the elevation of the top of the QTm and the definition of Qoa. The QTm in the geologic framework model is almost everywhere 400 to $600 \mathrm{ft}$ deeper than the previously published interpretation (figs. $17 A$ and $B$ ). The previously published interpretation of the QTm as portrayed on the north-south section $B$ - $B^{\prime}$ (fig. 17B) followed the geologic mapping of Dibblee (Dibblee, 1973; Graham and others, 1999; Dibblee and Minch, 2005b,c, 2007), which included all young, deformed, non-marine sediments of the Cuyama area in the Morales Formation. By using these criteria, the upland area that lies to the south of Cuyama Valley and north of the Sierra Madre Mountains was interpreted on the previously published section as being composed of exposed

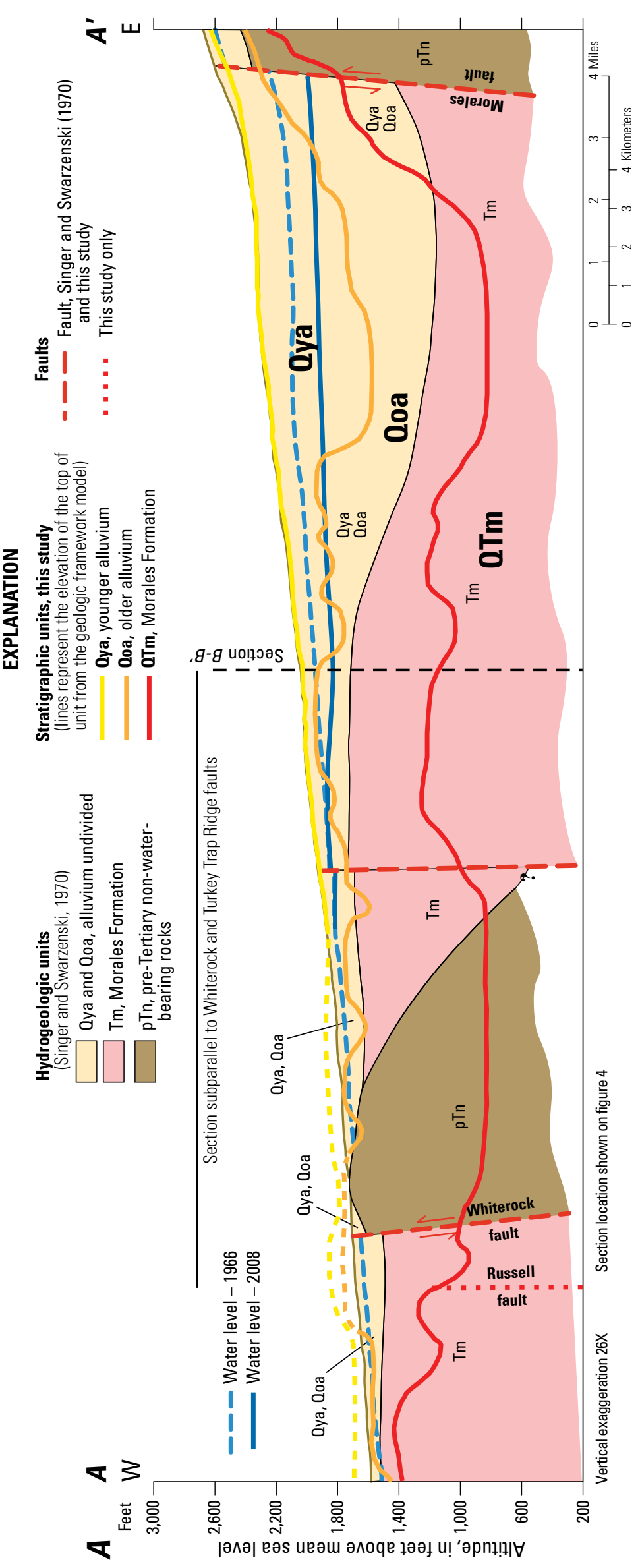


outcrops of Morales Formation (fig. 17B). Subsequent workers (Vedder, 1968; Vedder and Repenning, 1975; Schwing, 1984; Spitz, 1986; Kellogg and others, 2008) classified the upper part of Dibblee's mapped Morales Formation as "deformed older Quaternary alluvium," thus putting the Morales Formation a few hundred meters in the subsurface on the south side of Cuyama Valley, rather than exposed at the surface. Data from electric logs that were used in the construction of the geologic framework consistently place the top of the QTm deeper than Singer and Swarzenski (1970).

A second difference between information from previous publications and the model output is the definition of the top of the older alluvial unit Qoa, which was not subdivided from younger alluvium in previously published sections (figs. 17 $\mathrm{A}$ and $B$ ). Qoa in the geologic framework model includes both the lower part of the previously defined undivided Qya/Qoa and the upper part of the previously defined Morales Formation. For the geologic framework model, Qoa was subdivided from Qya primarily on the basis of degree of cementation. Differences in how such cementation was described in well drillers' reports could account for some of the irregularities in the elevation on the top of Qoa seen in section $A-A^{\prime}$ (fig. 17A). The topographic surface used for the previously published sections was generalized and ignored local irregularities, resulting in the shallow modeled unit tops appearing to go above the previously portrayed land surface on the western edge of section $A-A^{\prime}$. The sections showed general agreement on the location and character of the main basin-bounding faults. The geologic framework model adds the Russell fault at depth on the west edge of section $A-A^{\prime}$ and the Rehoboth fault on section $B$ - $B^{\prime}$ (fig. 16).
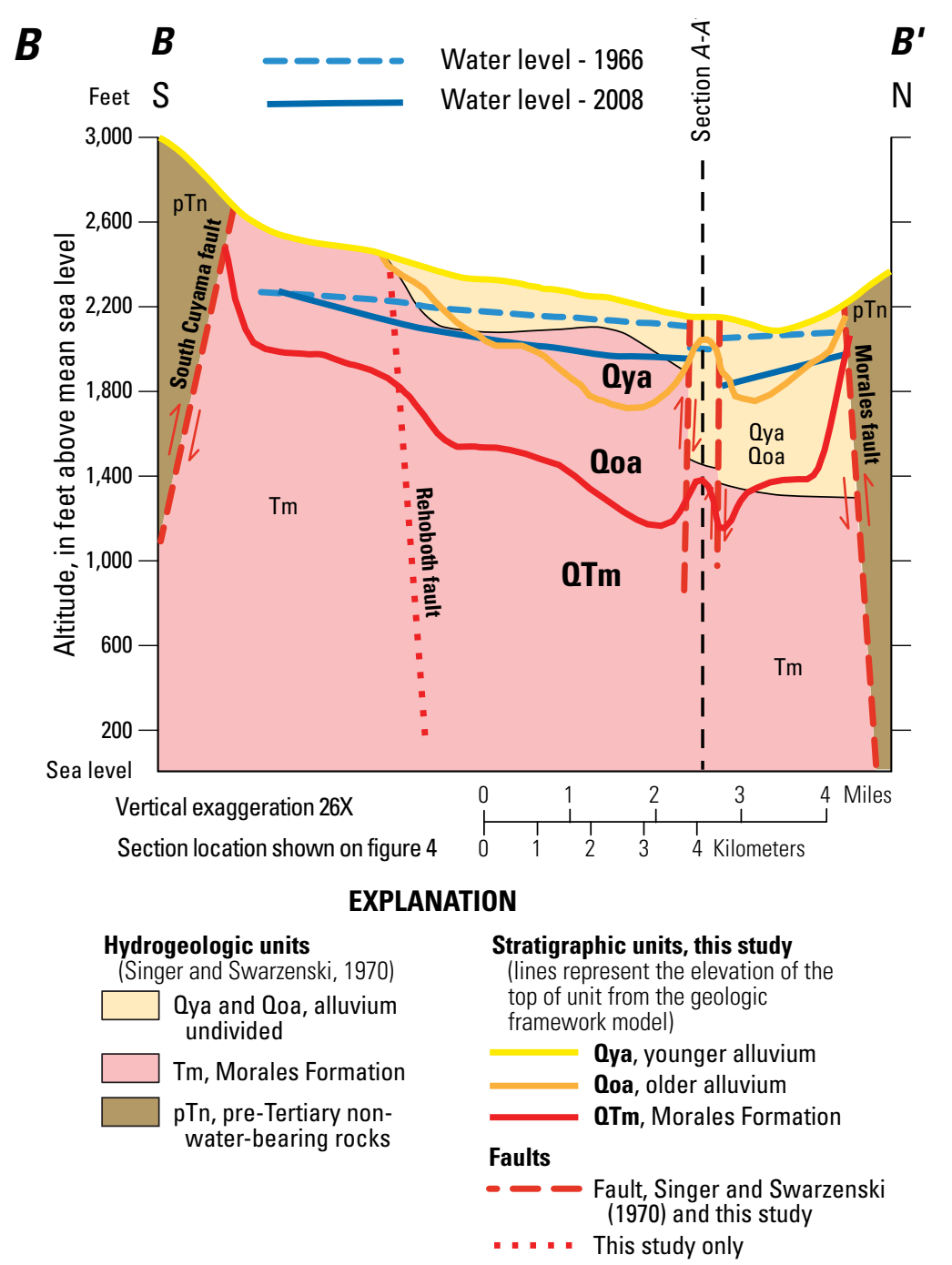

Figure 17. Cross sections showing previous hydrogeologic interpretation and elevation of stratigraphic unit tops from the geologic framework model. $B$, north-south section $B-B^{\prime}$.-Continued 


\section{Textural Analysis of Basin-Filling Unit}

An analysis of variability of lithology and grain size was completed for the three principal basin-filling units, Qya, Qoa, and the QTm. Textural data, such as grain size, sorting, and bedding characteristics, form the geologic basis for estimating the hydraulic properties within a numerical hydrologic-flow model (Burow and others, 2004; Faunt and others, 2010). Textural variability in the basin-filling units is ultimately a function of the sedimentary facies, environment of deposition, and depositional history of the basin. Textural data were compiled from 65 oil and gas and 153 water wells in the study area (fig. 18).

\section{Textural Variations Observed in Outcrop}

The Morales Formation is composed of up to $1,500 \mathrm{~m}$ of weakly indurated fluvial and alluvial sediments deposited in an extensive valley area. The unit is exposed in the Cuyama Badlands, is present in the subsurface beneath Cuyama Valley, and is also exposed on the north flank of the Caliente Range along the edge of the Carrizo Plain (fig. 4), where it was deposited prior to the thrust-related uplift of the range. In outcrop, the Morales Formation can be informally divided into a more poorly sorted, generally coarse-grained upper unit and a wellsorted, generally finer-grained lower unit (Dibblee and Minch, 2005a, 2006; Kellogg and others, 2008). The upper part of the Cuyama Badlands is about $700 \mathrm{~m}$ thick and is composed of weakly indurated, poorly sorted, matrix-supported cobblepebble conglomerate in a sandstone matrix (fig. 19A). The

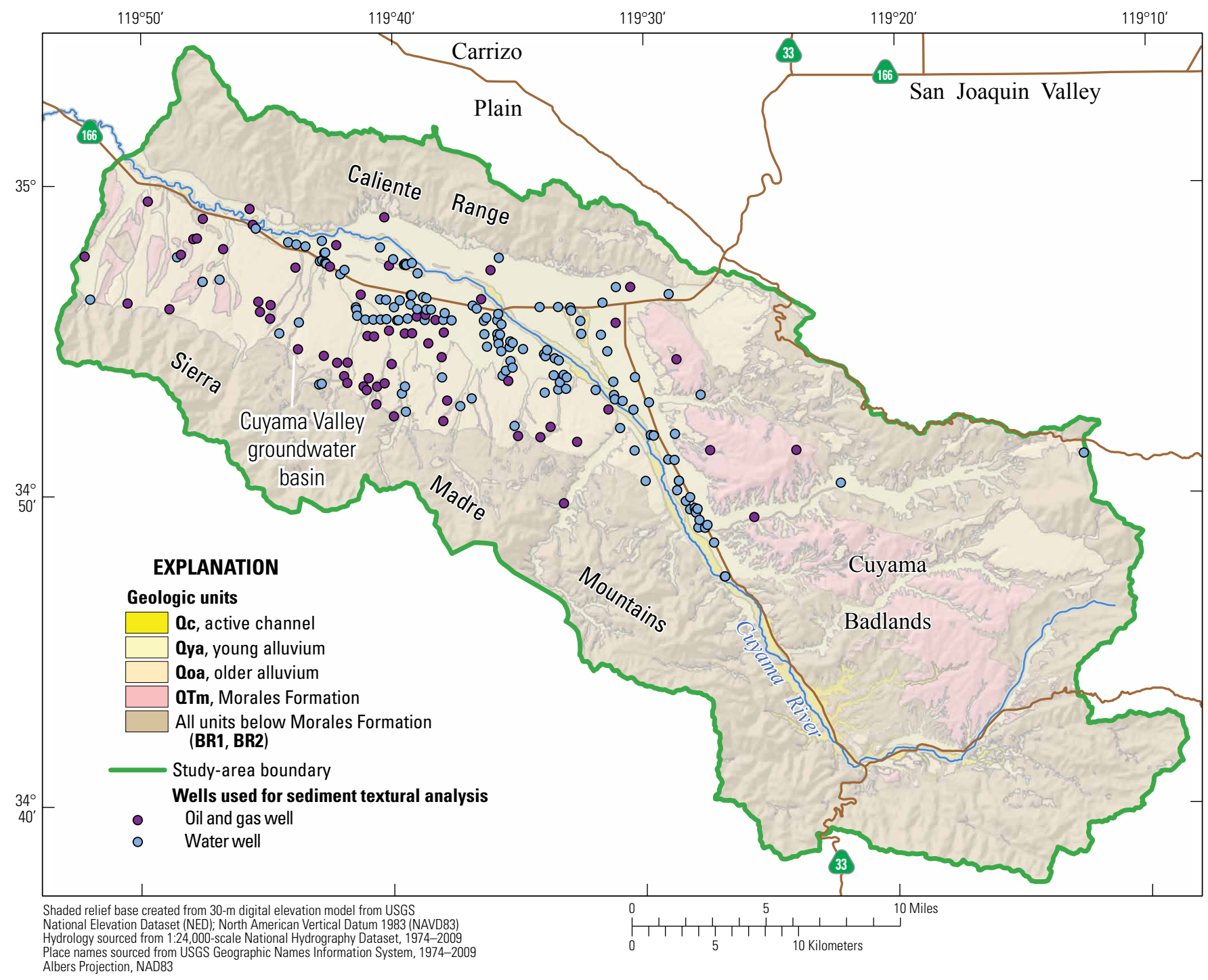

Figure 18. Location of wells used for textural analysis in Cuyama Valley. 


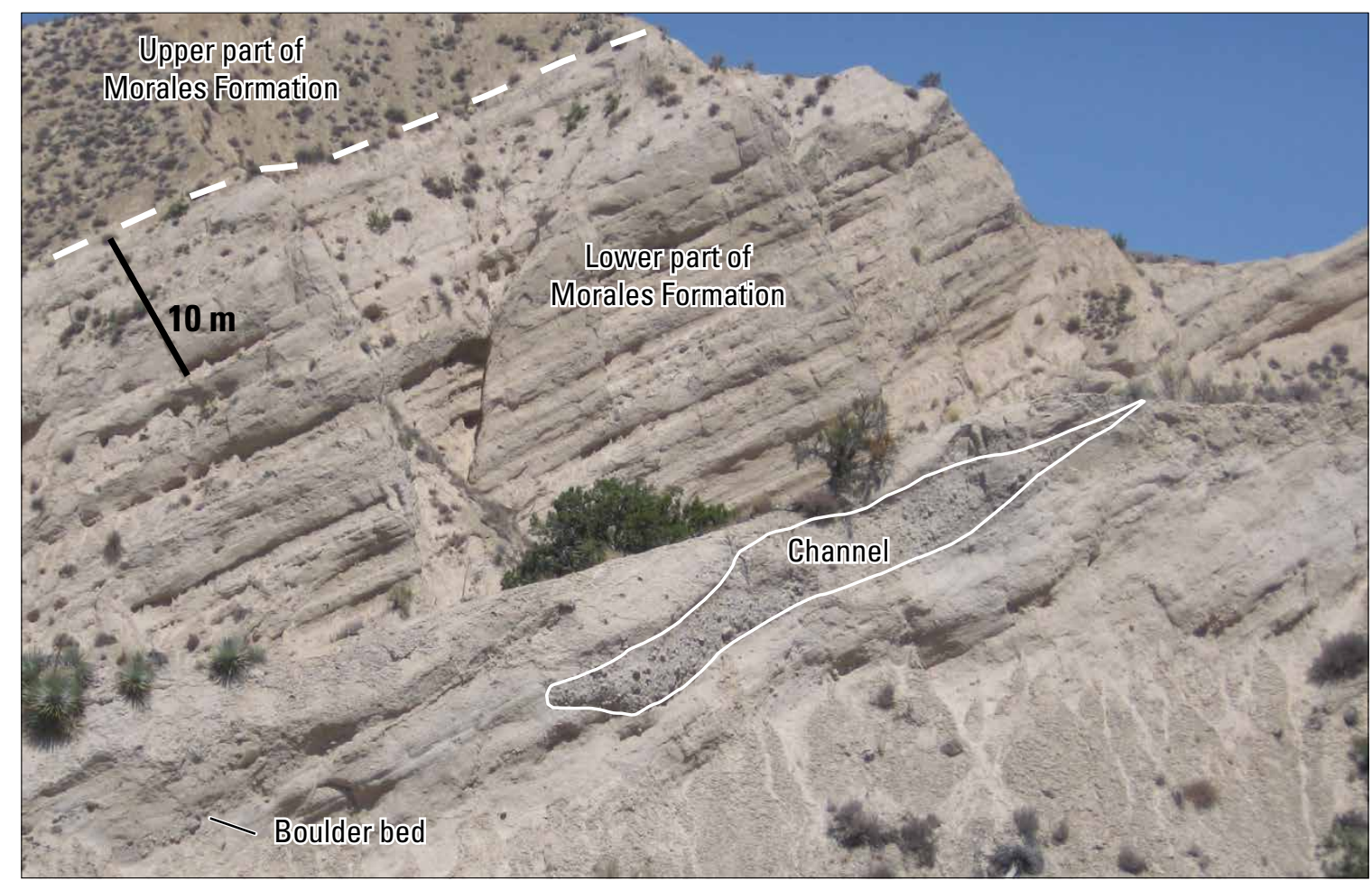

A. Morales Formation, Quatal Canyon

Photograph by Donald Sweetkind, U.S. Geological Survey

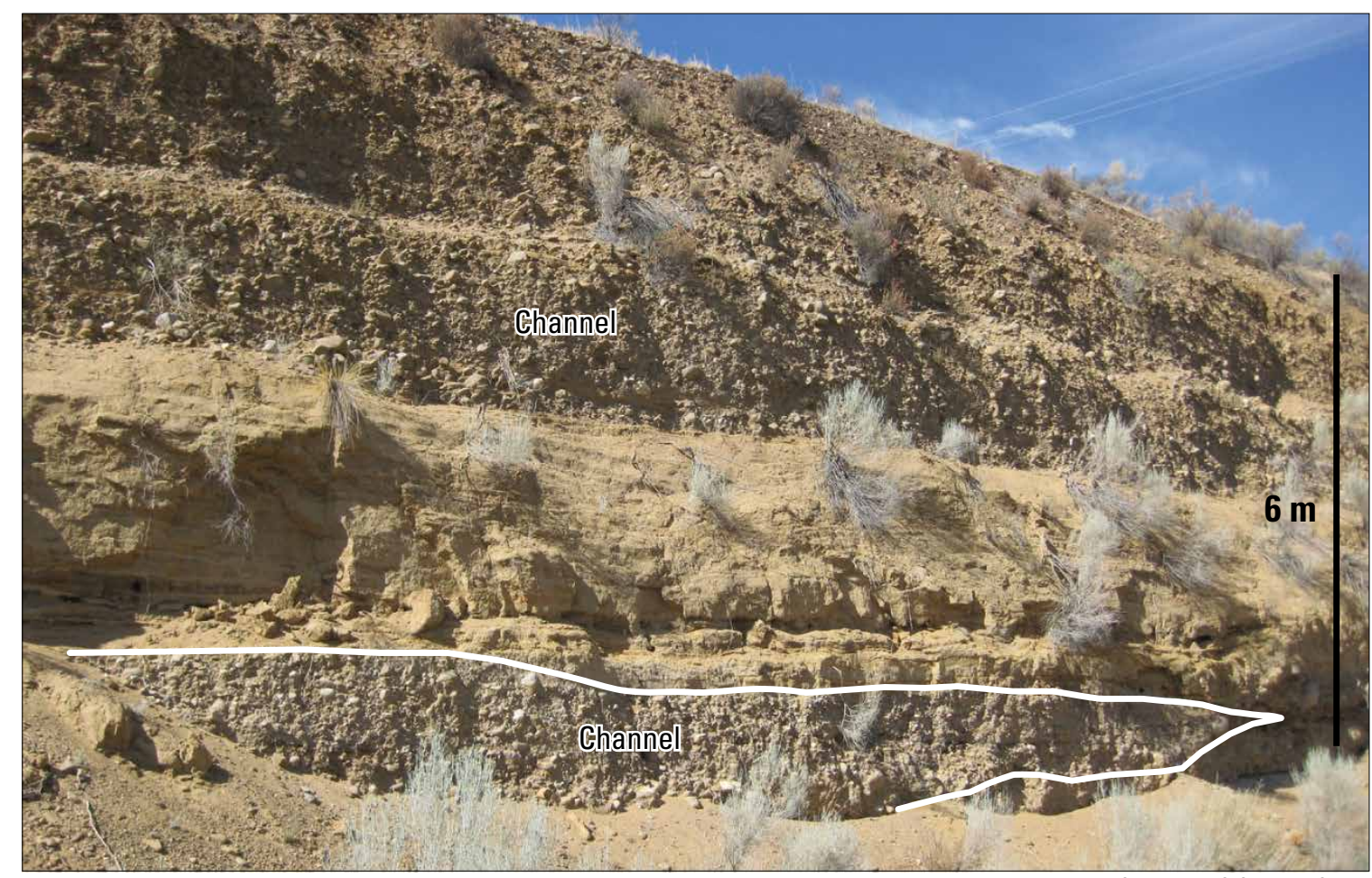

B. Qoa, along Highway 166, 5 kilometers west of New Cuyama

Photograph by Donald Sweetkind, U.S. Geological Survey

Figure 19. Outcrop expression of textural variations in basin-filling units: $A$, Morales Formation; $B$, Older alluvium. 
lower part is composed of about $650 \mathrm{~m}$ of thick- to massivelybedded arkosic sands with interbeds of pebble conglomerate and sandy siltstone (fig. 19A). In western Cuyama Valley, the lower part of the Morales Formation consists of about $400 \mathrm{~m}$ of gypsiferous lacustrine claystones that are conformably overlain by $500 \mathrm{~m}$ of sand and gravel.

The great thickness of thick-bedded to massively bedded arkosic sands, large area of deposition, and general lack of matrix-supported gravel deposits or well-defined channels indicate that the Morales Formation could have been deposited in a large streamflow-dominated alluvial fan system. Comglomerate clasts are a mixture of granitic rocks, gneiss, schist, quartzite, andesite, and basalt, whose sources are outcrops of crystalline rocks near the San Andreas fault, 20-30 km southeast of Cuyama Valley (Dibblee, 1982; Ellis, 1994; Kellogg and others, 2008). These clasts are evidence of long-distance transport from sediment sources at the margins of the broad depositional basin. Well and seismic-reflection data indicated that fine-grained intervals within the Morales Formation can be correlated in the subsurface for several kilometers.

Older alluvial deposits often consist of a sequence of boulder, clast-supported alluvial channel deposits separated by sandy interbeds (fig. 19B). Boulder clasts are typically of local origin and reflect nearby sources; deposits on the south side of Cuyama Valley often are dominated by clasts of Eocene sandstones derived from the Sierra Madre Mountains, whereas deposits on the northern side of the valley have a large proportion of Monterey shale clasts derived from the Caliente Range. Channel deposits are local-scale features that cannot be correlated for long distances. Younger alluvial deposits exposed in incised arroyos along the Cuyama River are dominated by tabular beds of fine to medium sand (DeLong and others, 2011).

The spatial distribution and sediment characteristics of the three basin-filling units are related to the Pliocene and Pleistocene tectonic evolution and uplift of the basin, the progressive narrowing of the valley, and the gradually increasing channelization of the Cuyama River drainage. The QTm is a widespread unit that was deposited prior to the constriction of the basin by encroaching thrust faults. The sediment supply to the QTm was from relatively distant sources, and the unit appears to have been deposited by streams in which the channel system was broad and poorly bounded. The inception of Pliocene compression and uplift caused thrust-bounded bedrock highlands to impinge upon the valley, and the drainages became more restricted to channels and, perhaps, higher gradient. As a result of tectonic uplift, previously deposited Morales Formation was exposed and eroded, feeding reworked sediment into a narrower basin, which resulted in the deposition of Qoa. Qya is confined to the center of Cuyama Valley and alluvial channels tributary to the Cuyama River. Textural variations in Qya appear to be primarily climate-driven and reflect regional rainfall variations that control stream incision and aggradation.

\section{Texture Derived from Drill-Hole Data}

Textural data were derived by using drillers' lithologic logs from water wells and by interpretation of electric logs from oil and gas wells. Water wells yielded data for lithologic intervals in the younger part of the section, primarily from Qya and the upper part of Qoa, whereas the oil wells yielded data primarily from QTm and the lower part of Qoa. The two types of wells produced different textural parameters; lithologic logs from water wells could be interpreted in terms of sediment grain size and the degree of sorting, whereas oil wells yielded textural parameters of grain size and bedding frequency.

\section{Oil and Gas Wells}

Textural data were derived from 65 oil and gas wells (fig. 18) by analyzing the electrical geophysical logs. The presence of fresh water as pore fluids in sand and gravel aquifers results in rightward deflections on resistivity logs to higher resistivity values and in leftward deflections to more negative values on the SP log; clays and shales are generally conductive and have low values of resistivity with rightward deflections to more positive values on the SP logs (Wyllie, 1957; Keys and MacCary, 1971; Johnson and Pile, 2002; fig. 20). Textural analysis used the deflection of the SP curve in the electric logs to approximate the sand-shale ratio, which is a technique often used in consolidated sand-shale sequences (Wyllie, 1957; Johnson and Pile, 2002), although not frequently applied to continental basin-fill deposits. Spontaneous potentials occur near boundaries between shale or clay and coarse-grained deposits. The polarity and amplitude of the SP-log deflection depend on lithology and the salinities of both the formation water and the borehole fluid. Assuming that coarse-grained and fine-grained beds within Qoa and QTm have similar formation water salinities, the sand-shale interpretations were made in reference to a shale baseline that was drawn on each electric log connecting the SP-log deflections to the most positive values. This shale baseline was defined by using SP-log deflections for the entire thickness of QTm and the underlying fine-grained Quatal Formation below. A sand line was constructed roughly parallel to the shale baseline by connecting the maximum deflections to negative values on the SP log. Variation of the SP curve between the maximum deflections is due to a variety of factors, including the relative clay content of the formation and the damping effect of thin beds, which tend to reduce the SP deflection even in cases of clean sands interbedded with pure shale (Wyllie, 1957; Keys and MacCary, 1971; Johnson and Pile, 2002).

The 100-mV scale of the SP curve was divided into four categories that corresponded to relative-size fractions, described as coarse, medium, fine and very fine (fig. 20). The finest and coarsest relative-size fractions were each assigned a $30-\mathrm{mV}$ range ( six vertical divisions, fig. 20); the middle two relative-size categories each occupied $20-\mathrm{mV}$ range on either side of the zero value. These divisions were assigned on the basis of the maximum SP-log deflections observed in 


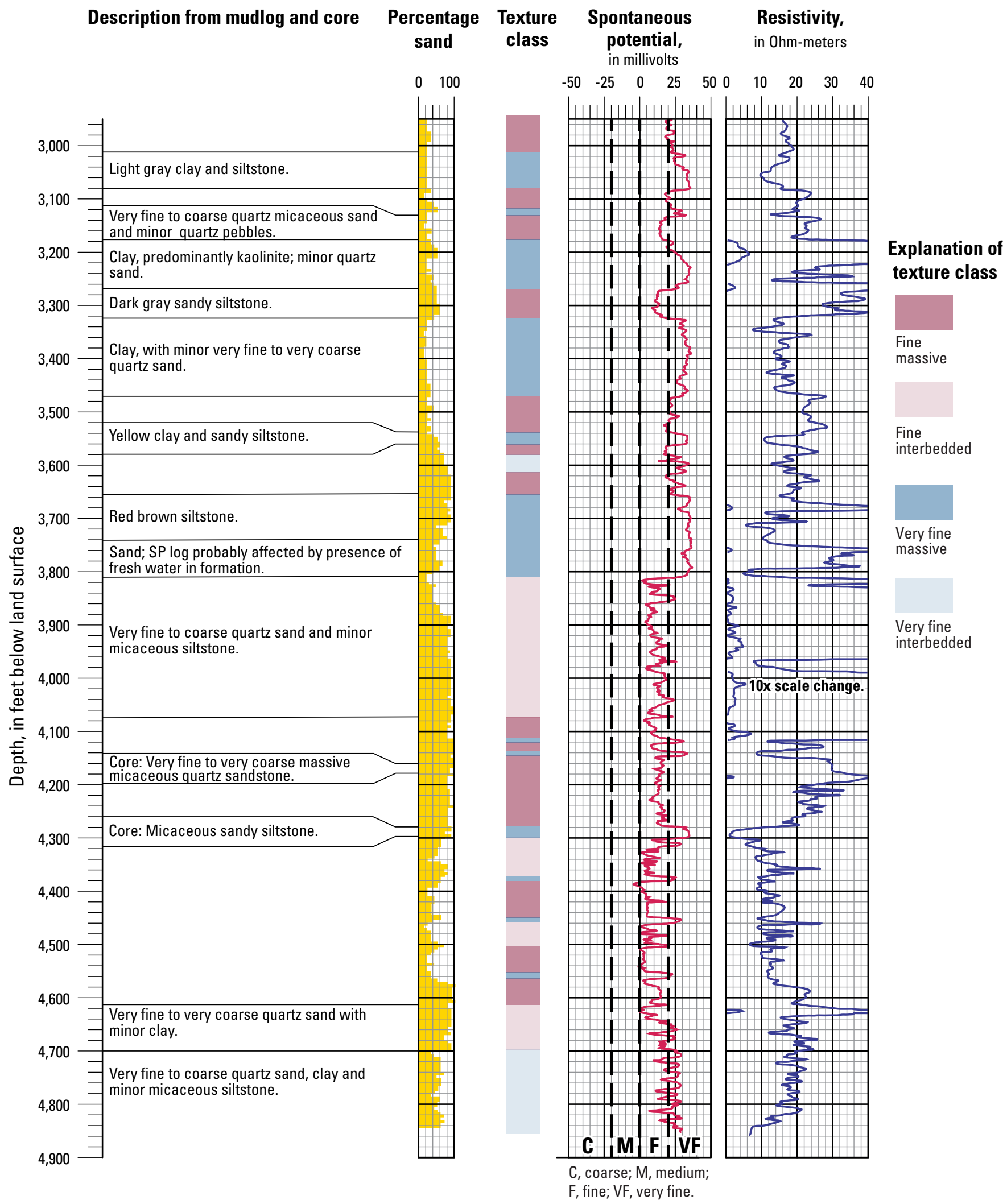

Figure 20. Example electric log from oil and gas well showing derivation of textural data. 
the Miocene rocks beneath the Morales Formation, where shale and sandstone were penetrated. The upper parts of the boreholes were logged by using the same SP-log scale as the deeper section, so that the magnitude of the deflection could be roughly calibrated to a known grain size. Down-hole intervals were then assigned a relative grain size on the basis of the location of the SP-log curve with respect to the category boundaries. Qoa tended to be characterized by numerous intervals that had SP-log deflections to large negative values that were described as coarse or medium relative-size fractions, whereas QTm tended to be characterized by relatively monotonous SP-log response in the fine to fine relative-size fractions.

Down-hole intervals were also classified by bedding frequency and described as either massive or interbedded (fig. 20). Massively bedded intervals were those where the SP curve remained within a relative-size category for at least $20 \mathrm{ft}$; interbedded intervals were characterized by frequent alternation between relative-size fractions at the scale of several feet in thickness. Thin beds tend to dampen the full response of the SP logging tool because the tool spans the thickness of multiple beds and integrates the spontaneous potentials developed at multiple unit contacts. For these units, the SP curve was augmented by the higher-resolution peaks of the resistivity curves to qualitatively discriminate between massively bedded units and thinly interbedded units.

The relative-size fractions derived from SP-log analysis compared favorably to mud-log descriptions, percentage sand analysis, and descriptions from sidewall cores (fig. 20). Although mud-log descriptions include a wide range of grain sizes, intervals described as siltstone corresponded to rightward deflections to more positive values on the SP logs that were classified as very fine, whereas sand-bearing intervals were consistently interpreted in the fine grain size class (fig. 20). Where lithologic descriptions were more general or applied to a large downhole interval, there was a general correspondence between the logged sand percentage and the SPlog results, such that sand-poor intervals corresponded to an interpreted grain-size class of very fine (fig. 20). Correspondence between observed lithology and interpreted grain-size class was strongest where relatively thick beds of uniformly coarse material were penetrated. Thin-bedded deposits tended to be described as mixtures of grain-size fractions in the mud logs. Shale or clay intervals recorded in the mud log rarely correlated well with a clear shale line on the SP-log, which, perhaps, was a result of the interbedded nature of the deposits or of the lag in cutting return coming up the drill hole. In some cases, the fine-grained fraction could have been underrepresented in the mud $\log$ when the drill cuttings were washed to remove drilling mud and fluids.

\section{Water Wells}

Textural data were derived from drillers' lithologic logs from 153 water wells in the study area (fig. 18). Drillers' descriptions are generally short phrases that accompany a significant lithologic change. Typically, descriptions range from one to ten words that describe a change recognized by the driller as the drill penetrates a different unit; for example, descriptions can include information on grain size, presence or absence of gravel or large rocks, degree of consolidation, and rock type or abrupt color changes. Each lithologic log was divided into a discrete binary texture classification of either "coarse grained" or "fine grained" intervals on the basis of the description in the log. In this study, coarse-grained sediment is defined as consisting of sand, gravel, pebbles, boulders, cobbles, or conglomerate. Fine-grained sediment is defined as consisting principally of clay, lime, loam, mud, or silt. These definitions of "coarse grained" and "fine grained" are similar to those originally defined by Page (1986) and later used by Laudon and Belitz (1991), Belitz and others (1993), and Burow and others (2004).

\section{2-D and 3-D Models of Textural Data}

Numerical hydrologic-flow models must represent the hydraulic conductivity of aquifers throughout the model volume. This can be accomplished through a 3-D array of values (Burow and others, 2004; Faunt, 2009) or as a 2-D representation in plan view where the model domain is subdivided into zones that represent areas with the same hydraulic properties within individual aquifers (Faunt, Blainey, and others, 2010). Textural data were analyzed in both 2-D and 3-D to help define textural variations in the Cuyama Valley groundwater basin in ways potentially useful for a numerical hydrologicflow model. Ultimately, sediment grain size, a textural parameter common to both the oil and water well data, was modeled by using geostatistical methods to produce 2-D estimates of grain-size variability for each principal basin-filling unit.

\section{3-D Model of Textural Data from Oil Wells}

The interpreted grain-size and bedding-frequency parameters derived from the oil and gas exploration holes were used to construct a 3-D solid model of textural variations within the basin by extrapolating data away from boreholes by using a nearest-neighbor 3-D-gridding process within a 3-D software modeling package (fig. 21). The 3-D-gridding process is a cell-based modeling approach where solid-model cell nodes are sequentially assigned properties outward horizontally from each borehole in circles of increasing diameter. The approach is a simple spatial interpolation method that does not consider spatial structure of the data. Cell dimensions for the modeling were $500 \mathrm{~m}$ in the horizontal dimensions and $10 \mathrm{~m}$ in the vertical dimension. The $\mathrm{x}, \mathrm{y}$ cell dimensions were chosen to mimic the closest spacing of the oil and gas wells, and the vertical dimension was chosen to preserve the textural detail obtained from the SP-log analysis. The extrapolated lithologic data in the resulting solid model have the appearance of stratigraphic units with aspect ratios that emphasize the horizontal dimension relative to the vertical dimension.

A series of vertical northwest-southeast and northeastsouthwest sections through the 3-D solid lithologic model 


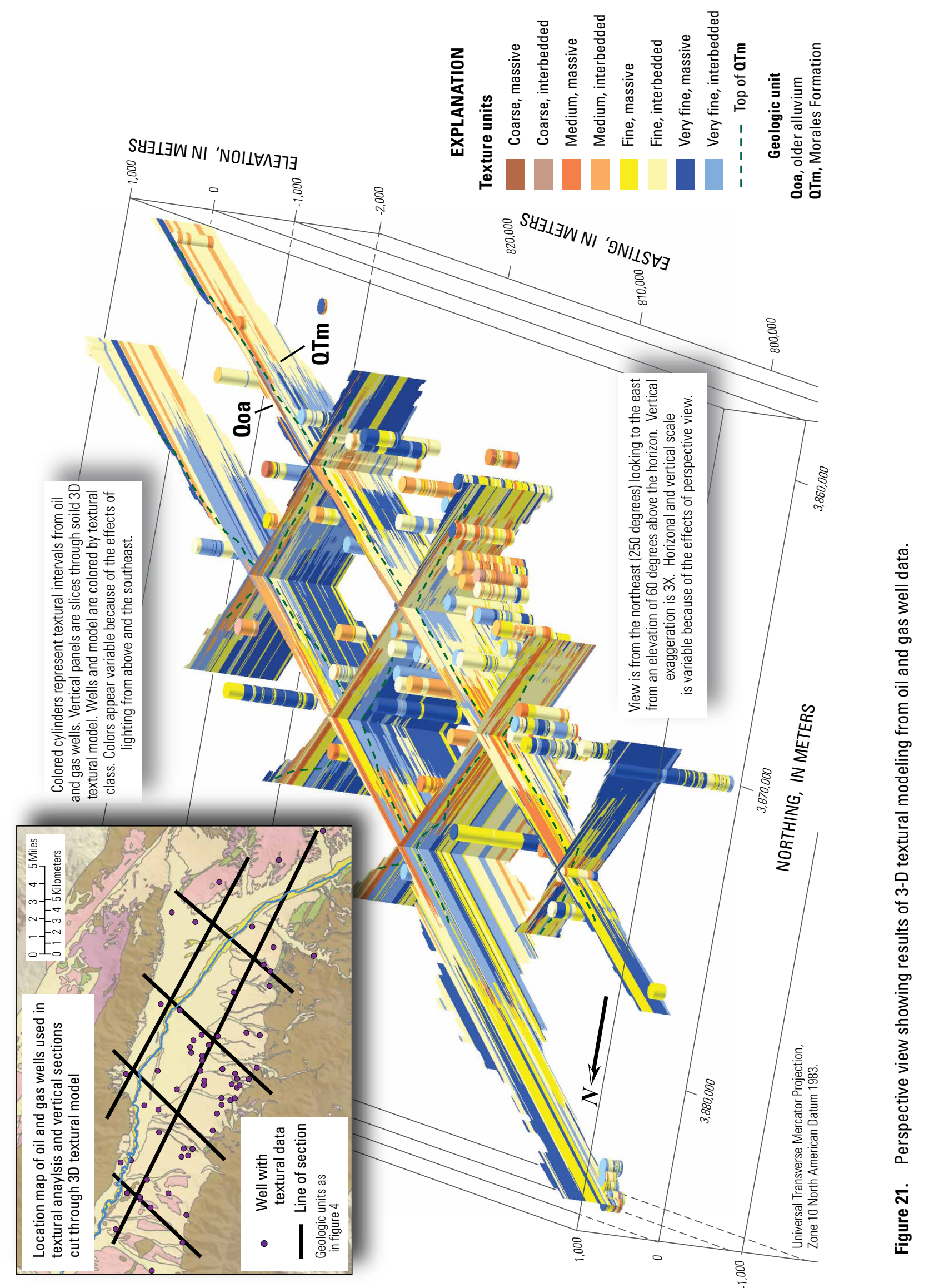


portray the lithologic variability of the basin fill in the Cuyama Valley region as extrapolated from the oil and gas borehole data (fig. 21). The upper surface of the 3-D solid lithologic model is clipped at the topographic surface by using a digital elevation model; the base of the model is clipped with the modeled base of QTm. Mountainous regions that are underlain by bedrock around the basin margins are uncolored (fig. 21).

The 3-D solid model shows the relative extents of coarseand fine-grained sediments in the shallow subsurface and highlights textural differences between the Qoa and QTm units (fig. 21). Qoa is generally coarser than the QTm and has more numerous medium- and coarse-grained lenses, which probably represent alluvial channel deposits. The QTm has relatively few coarse-grained intervals and is characterized by relatively fine-grained material, particularly in the axis of the valley where Qoa contains some of the coarsest intervals. The QTm becomes more coarse-grained along the southern flank of the valley and to the southeast, perhaps reflecting available sediment supply from uplifting areas outside the valley.

The 3-D modeling approach was ultimately limited by the extrapolation methodology. The method preserved the local variability of the lithology where data were abundant, but resulted in poorer extrapolation where drill holes were widely spaced and the outlying points influenced a large part of the model volume. A series of plan-view zones of texture variation was envisioned as input for the numerical flow model, and 2-D extrapolation methods, described in the following section, were ultimately used rather than the 3-D approach.

\section{2-D Models of Textural Data}

Geologic or hydrogeologic units are the basis for assigning horizontal hydraulic conductivity to the cells of a numerical flow model grid within the groundwater modeling code MODFLOW-2000 (Anderman and Hill, 2000, 2003). Lateral variations in horizontal hydraulic-conductivity,or the material's capacity to transmit water in the $\mathrm{x}-\mathrm{y}$ plane parallel to bedding, can be assigned through the use of the zonation capability of the Hydrogeologic-Unit Flow (HUF) package of MODFLOW-2000 (Anderman and Hill, 2000). Zones are used to define areas with similar properties within individual geologic or hydrogeologic units. For eventual use within a numerical hydrologic-flow model, 2-D (map view) models of textural data from both oil and water wells were created for the geologic units, Qya, Qoa, and the QTm, to define areas with similar geologic materials that are likely to have fairly uniform hydraulic properties.

Similar to previous studies (Phillips and Belitz, 1991; Burow and others, 2004; Faunt, 2009), the primary variable used in the textural analysis was sediment grain size, tabulated as percentage of coarse-grained texture. Down-hole intervals from both oil and water wells were classified as either coarse or fine grained. For water wells, coarse-grained deposits were those dominated by gravel and sand-size clasts with no clay matrix; all other lithology classes were considered finegrained. Even units that had a considerable fraction of large clasts were classified as fine-grained if the clasts tended to be suspended in a fine-grained matrix. For oil wells, coarse and medium texture classes derived from the SP-log curve were assigned as coarse grained; fine and very fine classes were assigned as fine grained. The binary classification of intervals as either coarse or fine grained helped account for the lack of an exact correspondence between grain size as described in drillers' lithologic logs and the relative size classes derived from SP-log analysis. For use in statistical and geostatistical analysis, the percentage of coarse-grained sediment was calculated for the entire thickness of each geologic unit for 218 wells (table 3 ). The percentage of coarse-grained sediment was calculated as the total thickness of coarse-grained intervals divided by the total thickness of the geologic unit. The global mean percentage of coarse-grained texture was 34 percent, with young alluvium being significantly more coarse than older alluvium or the Morales Formation (table 3).

Because the hydrologic-flow model was subdivided on the bassis of three geologic units, sediment texture was estimated at the nodes of a 2-D grid for each unit. The textural parameter represents an average value that applies to the entire thickness of the geologic unit. This grid node-based averaging provides a measure of spatial variability for the unit in the $x, y$ dimensions, but eliminates any portrayal of textural variability in the $z$ direction within the unit. The density of wells in the center of the groundwater basin is sufficient to model the texture of each geologic unit on a 250-m horizontal grid. Data density throughout the study region varied on the basis of the availability of data. This variable sample density did not appear to bias the statistics used to describe the $\mathrm{x}, \mathrm{y}, \mathrm{z}$ values. The data were not declustered prior to the geostatistical modeling. The grid was oriented with the long axis roughly parallel to Cuyama Valley axis and has a uniform cell spacing of $250 \mathrm{~m}$ in the $\mathrm{x}$ and $\mathrm{y}$ directions consisting of 300 cells in the $\mathrm{x}$-direction and 135 in the $y$-direction. The textural data at wells represented x,y point values for each geologic unit.

Coarse-grained texture was extrapolated away from the well data for each geologic unit by using the geostatistical

Table 3. Summary of logs used for textural analysis by geologic unit.

[Qya, Younger alluvium; Qoa, Older alluvium; QTm, Morales formation]

\begin{tabular}{lcccc}
\hline $\begin{array}{c}\text { Geologic unit } \\
\text { (abbreviation) }\end{array}$ & $\begin{array}{c}\text { Number } \\
\text { of records }\end{array}$ & $\begin{array}{c}\text { Maximum } \\
\text { thickness } \\
\text { (feet) }\end{array}$ & $\begin{array}{c}\text { Average } \\
\text { thickness } \\
\text { (feet) }\end{array}$ & $\begin{array}{c}\text { Percentage } \\
\text { coarse }\end{array}$ \\
\hline $\begin{array}{c}\text { Younger alluvium } \\
\text { (Qya) }\end{array}$ & 119 & 193 & 92 & 59 \\
$\begin{array}{l}\text { Older alluvium } \\
\text { (Qoa) }\end{array}$ & 154 & 354 & 171 & 36 \\
$\begin{array}{c}\text { Morales Formation } \\
\text { (QTm) }\end{array}$ & 120 & 1,384 & 754 & 31 \\
All & 235 & 1,637 & 868 & 34 \\
\hline
\end{tabular}

${ }^{1}$ Records for each unit do not sum to the total shown in "All" because wells can penetrate more than one unit down hole. 
method of ordinary kriging in a similar fashion to methods used by Burow and others (2004) and Faunt and others (2010). An advantage of using geostatistics instead of simple spatial interpolation methods, such as inverse-distance weighted interpolation, is that the geostatistical model is fitted to the observed spatial correlation structure, whereas simple interpolation methods are based on an assumed spatial correlation structure. Kriging is based on the assumption that the parameter being interpolated varies in a continuous manner from one location to the next, such that points that are near each other have a certain degree of spatial correlation, but points that are widely separated are not spatially correlated (Journel and Huijbregts, 1978; Isaaks and Srivastava, 1989). Anisotropy, or the directional component of the spatial dependence, in the spatial correlation structure can be obtained by combining several different models aligned along its principal axis to form a nested set of models.

2-D semivariograms that displayed differences in the percentage of coarse-grained sediment between pairs of points at different distances were developed in order to investigate the spatial correlation of the textural data (table 4). The semivariograms reflected the geometry and depositional environment of Cuyama Valley in that they typically have a horizontal range in kilometers along the axis of the valley and half that perpendicular to the valley axis (table 4). Typically, the semivariograms displayed a nugget, or variance at very close sample spacing, indicating textural variability at scales smaller than the distance between neighboring well data. Semivariograms were calculated by using a moving window with at least two nearest neighbors and an optimum of five nearest neighbors. The semivariograms were fitted with curves or variogram models that best fit the data. Each model included a nugget and used an exponential variogram model; in some cases the data were best fit using multiple, or nested, variagram models. Anisotropy that was observed in the semivariograms was best fit by setting the major anisotropic axis close to the trend of the valley axis, parallel to the main river channel, and the minor anisotropic axis perpendicular to this axis, close to the trend of the tributaries and fans (table 4).
2-D kriging was used to extrapolate coarse-grained texture to each $\mathrm{x}, \mathrm{y}$ grid node for the entire thickness of the geologic unit. To augment the textural parameter for alluvial units Qya and Qoa, the digital elevation model was introduced as a second data set, and texture was computed by using co-kriging. Textural data for Qya and Qoa exhibited some correlation with elevation where these deposits were in channels or on alluvial fans. Co-kriging tended to improve the textural interpolation, especially in drainages with few or no well data, such that the primary texture variable was considerably undersampled.

The spatial dimensions of the search neighborhood were not constrained; therefore, for locations of the estimation grid having densely-spaced wells, the effective search neighborhood was relatively small. For locations of the estimation grid that contained widely-spaced wells, the effective search neighborhood expanded laterally until at least two texture values were reached. Although the estimation neighborhood used at least two values for each kriged estimate, most estimates in the corners and along the boundaries of the grid were extrapolated rather than interpolated values.

As is indicated by the nugget and range of the variograms, the assumption that texture at any point in heterogeneous alluvial sediments is related to texture at surrounding points several kilometers away might not always be valid. Therefore, in areas of sparse data, the texture maps are to be regarded as only showing general trends and averages. Conversely, in areas where nearby data are variable and there is a significant relative nugget in the variogram model, the 3-D kriging can produce smoothed estimates. This results because the kriging algorithm aims to find a least-squares estimate of the expected value; therefore, the more data that are included in the estimate, the smoother the estimate will be.

The spatial patterns of the percentage of coarse-grained texture are shown in texture maps of the three basin-fill units (figs. 22-24). The 2-D kriged estimates of percentage of coarse-grained texture showed significant heterogeneity in the texture of the sediments that reflects the depositional environment and the geomorphic evolution of the region since the Pliocene. The spatial structure of the kriged textural model for the young alluvium can be attributed to the alignment of the active drainages, whereas the textural models of the older units were less correlated to modern topography.

Table 4. Kriging parameters used for textural analysis.

[-, second dataset not used; DEM, digital elevation model; $\mathrm{m}$, meters]

\begin{tabular}{|c|c|c|c|c|c|c|c|c|}
\hline Geologic unit (abbreviation) & Method & $\begin{array}{l}\text { Second } \\
\text { dataset }\end{array}$ & $\begin{array}{c}\text { Major }^{1} \\
\text { (meters) }\end{array}$ & $\begin{array}{c}\text { Minor }^{2} \\
\text { (meters) }\end{array}$ & $\begin{array}{l}\text { Direction }^{3} \\
\text { (degrees) }^{\text {deges }}\end{array}$ & $\begin{array}{c}\text { Sill, } \\
\text { (percent) }\end{array}$ & Lag & $\begin{array}{c}\text { Nugget, } \\
\text { (percent) }\end{array}$ \\
\hline Younger alluvium (Qya) & Co-kriging & DEM & 19,200 & 11,500 & 105 & 10 & $\begin{array}{l}12 \text { lags of } \\
1,600 \mathrm{~m}\end{array}$ & 6 \\
\hline Older alluvium (Qoa) & Co-kriging & DEM & 14,400 & 8,900 & 107 & 3.5 & $\begin{array}{l}12 \text { lags of } \\
1,200 \mathrm{~m}\end{array}$ & 9 \\
\hline Morales Formation (QTm) & Kriging & - & 8,000 & 2,715 & 80 & 4.2 & $\begin{array}{l}8 \text { lags of } \\
1,000 \mathrm{~m}\end{array}$ & 7 \\
\hline
\end{tabular}

Distance to the sill or correlation length along the major anisotropic axis.

${ }^{2}$ Distance to the sill or correlation length along the minor anisotropic axis.

${ }^{3}$ Direction reported in degrees measured clockwise from north. 


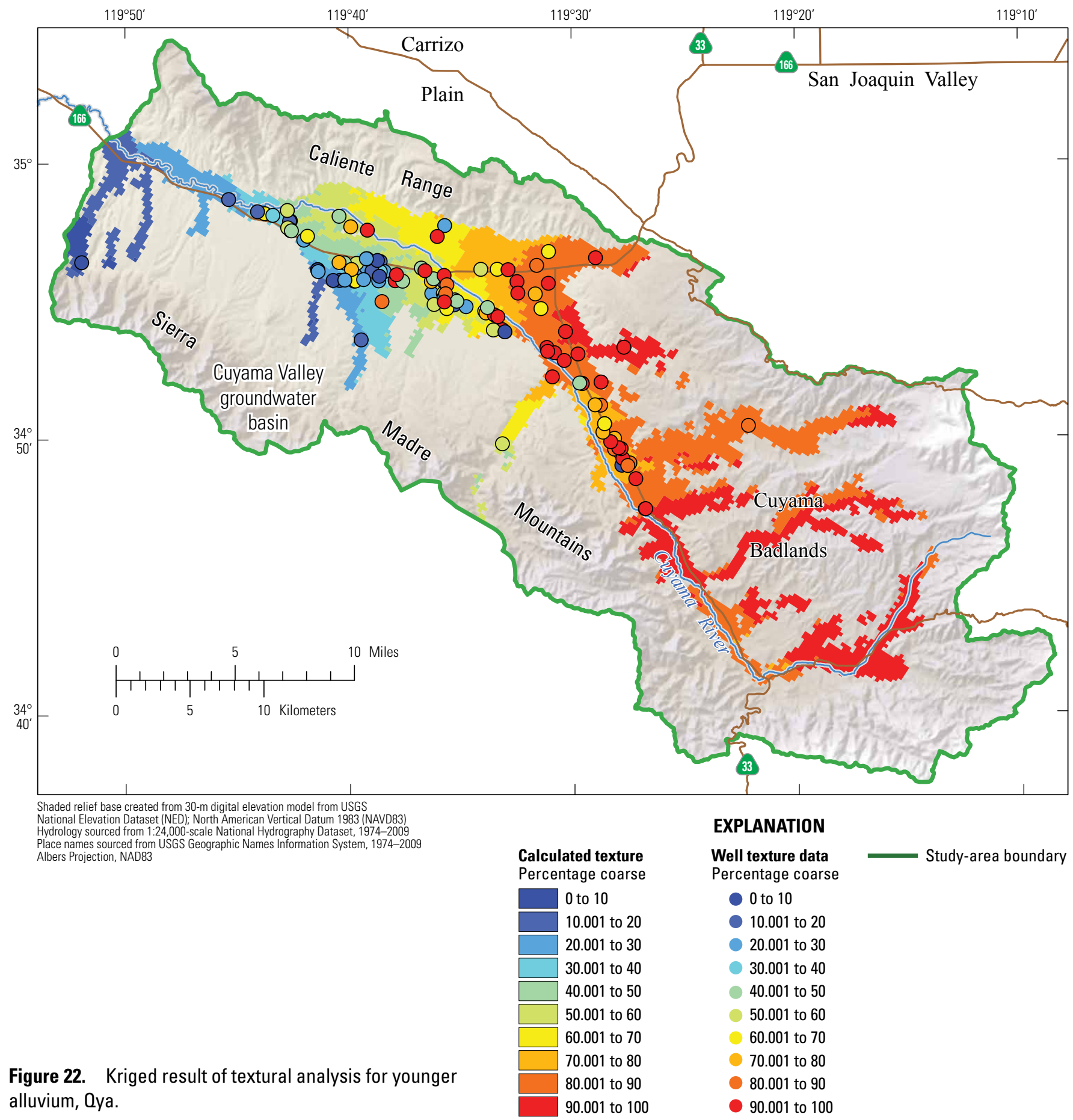

Figure 22. Kriged result of textural analysis for younger

\section{EXPLANATION}

Well texture data

0 to 10

10.001 to 20

.001 to 30

30.001 to 40

40.001 to 50

50.001 to 60

60.001 to 70

80.001 to 90

90.001 to 100
The texture model of Qya had the highest percentage of coarse deposits of the three units (fig. 22). The coarse-grained nature of the Qya reflects a number of factors, including the short distances between the sediment sources in the surrounding uplands and the sites of sediment deposition as well as the high-energy nature of Cuyama River and tributary creeks that transport sediments during winter storms and summer monsoonal rains. Because the basin is relatively small, the Cuyama
River is able to carry a large bed load long distances through a large percentage of the valley. Coarse-grained sediment input also comes from several tributary drainages in the southeastern part of the study area that have relatively large catchment areas (fig. 22).

The texture model for Qoa differs in spatial structure from Qya in being overall much finer-grained and generally unrelated to the modern active drainages (fig. 23). Much of Qoa 


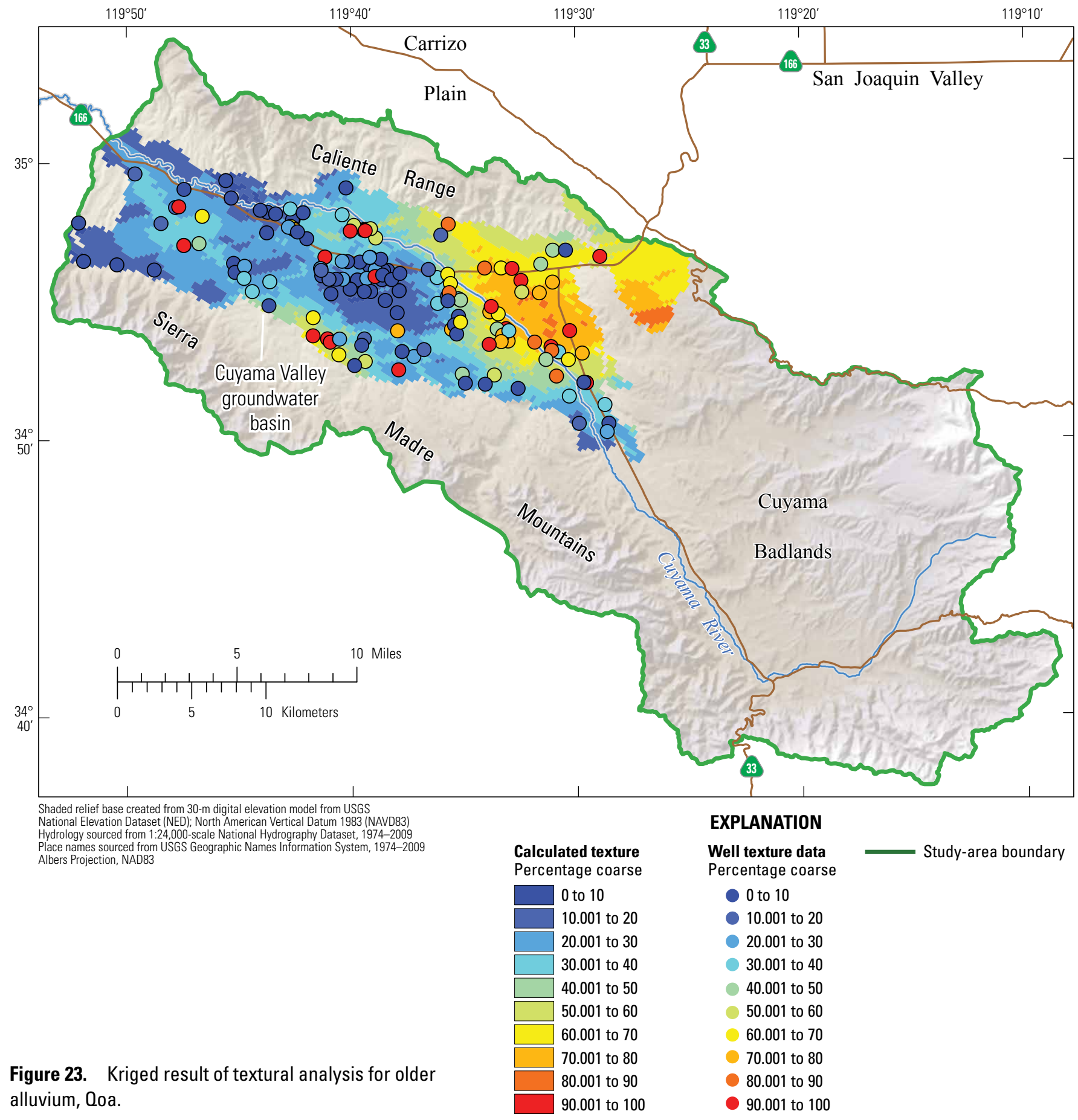

is derived from erosional reworking of uplifted parts of the Morales Formation. This reworking of previously-deposited sediment could account for the generally fine-grained nature of Qoa in the western half of the study area (fig. 23). Many of the wells throughout the valley are variable in their percentage of coarse-grained deposits in the Qoa, which could reflect the presence of local coarse-grained channels that affects the percentage of coarse-grained material when averaged over the entire thickness of the unit. A region of consistently coarsegrained material exists in the eastern part of the study area and could reflect an older stream channel alignment or the depositional site of sediments shed to the northwest off the uplifting Cuyama Badlands (fig. 23).

The QTm is much finer-grained than the overlying units (fig. 24). The QTm is particularly fine grained in the western half of Cuyama Valley, where surface geologic mapping identifies a lacustrine facies in this unit (Upson and Worts, 1951; Dibblee and Minch, 2005d; DeLong and others, 2008). This region of fine-grained material, and distinct fine-grained intervals within the Morales Formation, could reflect a 


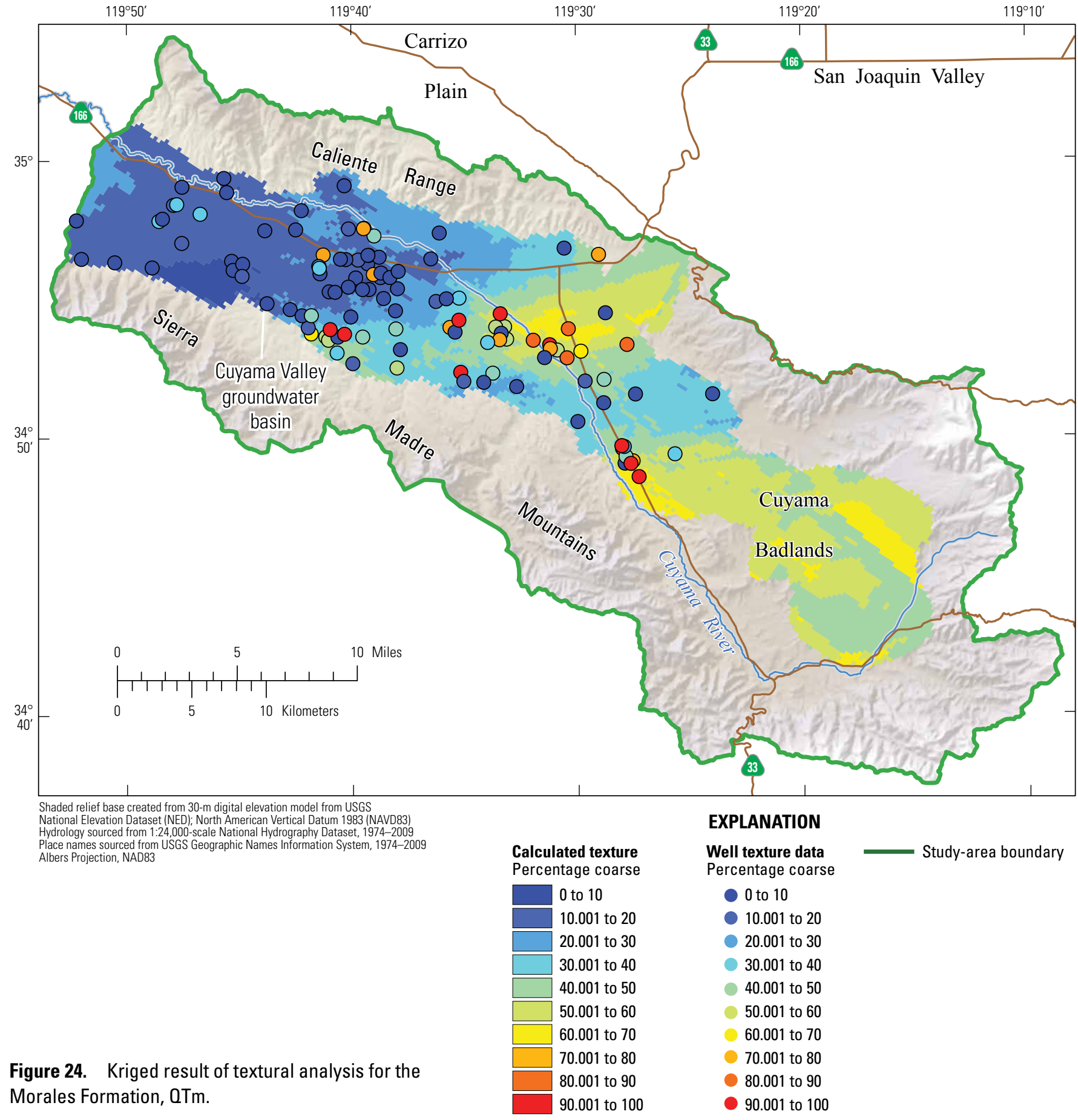

relatively distant sediment supply and temporary disruption of sediment transport in the Cuyama River drainage as a result of episodic uplift of the Sierra Madre Mountains at the west end of the valley (Dibblee, 1976). There are broad regions of relatively coarse material in the vicinity of the Cuyama Badlands (fig. 24). These areas are generally unrelated to the modern active drainages and represent deposition of alluvial materials prior to the development of modern topography.

The modeled percentage of coarse-grained sediment for each of the three basin-filling units is shown in perspective view in figure 25 along the two lines of section from Singer and Swarzenski (1970; fig. 17). The percentage of coarsegrained sediment was calculated for the entire thickness of each basin-filling unit for 250-m grid cells throughout the Cuyama Valley study area. The modeled result is portrayed in figure 25 for only those grid nodes that fall along the two lines of section. In this view, the kriged textural results are portrayed in grid cells that have fixed x,y dimensions, but variable height that is governed by the modeled elevation of the top and base of each unit within the geologic framework model 


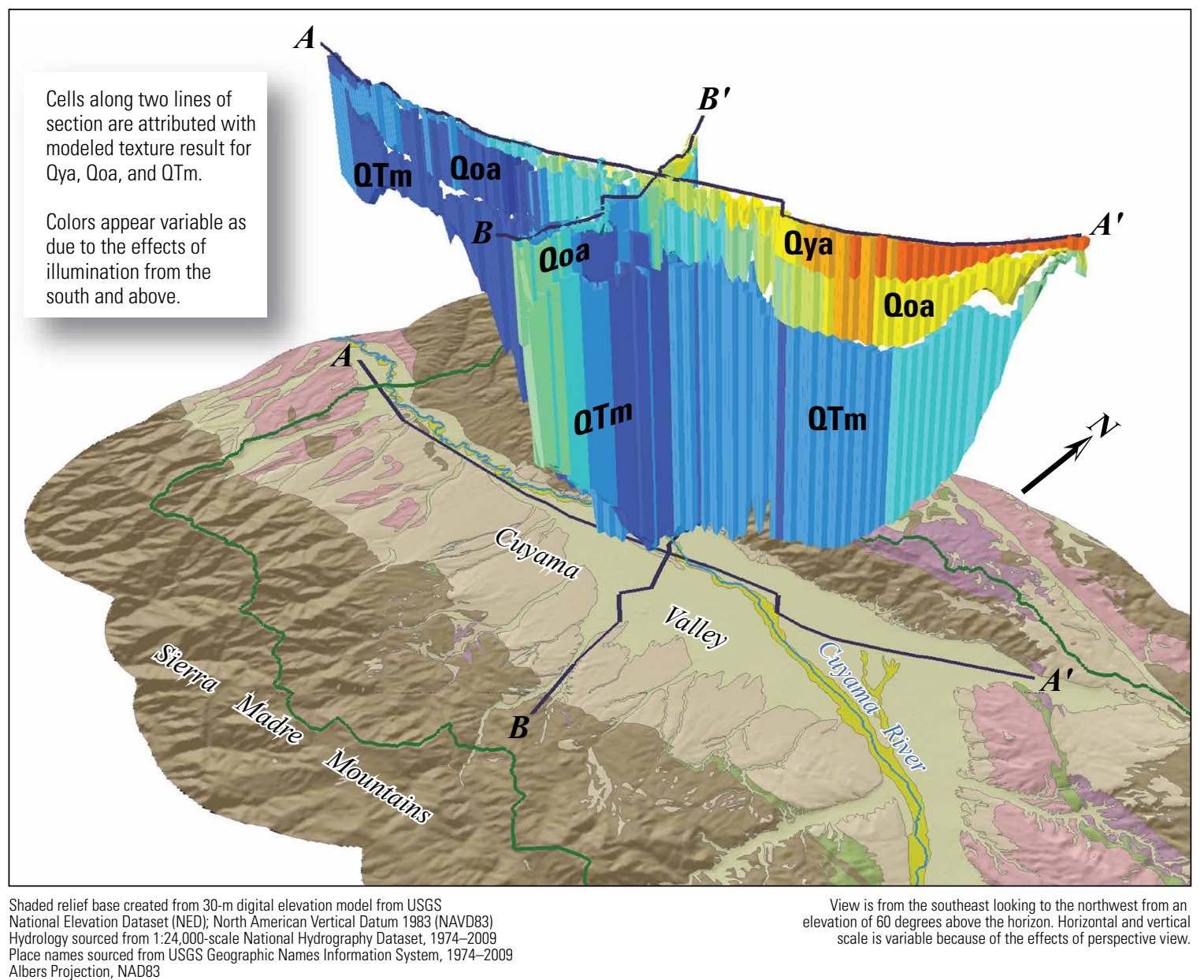

Place names sourced from USGS Geographic Names Information System, 1974-2009

EXPLANATION
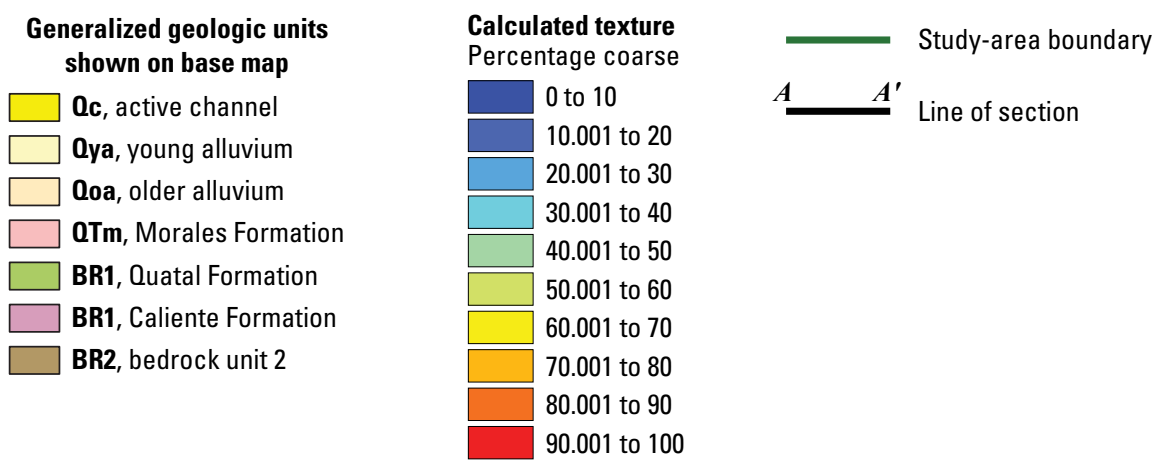

Figure 25. Perspective view showing result of kriged textural models for the younger alluvium, older alluvium, and Morales Formation units (Qya, Qoa, and $0 T m$ ) along two vertical sections.

(fig. 25). Numerical effects resulting from the sampling of the stratigraphic unit tops and the textural models along the lines of section cause minor local gaps between grid cells between units. The geologic map and the map trace of the section are shown at an arbitrary depth below the modeled texture result for locational purposes (fig. 25).

Qya has the coarsest modeled grain size of the three basinfilling units; it is the coarsest in the vicinity of the active Cuyama River channel. Kriged textural results from Qoa are moderately coarse-grained in the eastern half of Cuyama Valley, but transition to fine-grained at the western end of the valley. Modeled texture results for the QTm portray it as being generally fine-grained, particularly at the west end of the valley (fig. 25). The south end of section $B$ - $B$ ' shows a slight relative increase in the modeled percentage of coarse-grained sediment, which could reflect proximity to sediment sources along the uplifted southern edge of the basin. 


\section{Summary}

Water-resource management concerns have prompted an evaluation of the hydrogeology and water availability of the Cuyama Valley groundwater basin by the U.S. Geological Survey (USGS), in cooperation with the Water Agency Division of the Santa Barbara County Department of Public Works. The eventual construction and use of a numerical hydrologicflow model of the basin drives the need for (a) a conceptual understanding of the geologic setting of the Cuyama Valley groundwater basin; (b) the construction of three-dimensional digital models of the geologic framework of the basin; and (c) an analysis of the spatial variability of lithology and grain size to form the geologic basis for estimating the aquifer hydraulic properties. Previous work has outlined the overall shape of the basin, located many of the faults, and delineated and characterized aquifers in the saturated parts of the younger and older alluvium - units that historically have yielded most of the water pumped in the study area. This report builds on that work by creating three-dimensional digital datasets suitable for incorporation within a numerical hydrologic-flow model and includes greater detail for the deeper stratigraphic units of the groundwater basin, which were not previously investigated in detail.

A several hundred meter-thick section of Pliocene continental deposits and Pleistocene alluvial sediments constitutes the principal groundwater aquifer of the Cuyama Valley groundwater basin. This section can be subdivided into three principal stratigraphic units: Qya, younger alluvium; Qoa, older alluvium; and QTm, the Morales Formation. The two alluvial units are distinguished on the basis of degree of cementation and the amount of dissection and deformation. The QTm is an alluvial and fluvial deposit characterized by relatively fine-grain size, general lack of coarse channel deposits, and greater amounts of clay compared to the overlying section. Consolidated rocks that lie beneath the Morales Formation are generally non-water bearing.

A geologic framework model was constructed to represent the subsurface geometry of the stratigraphic units, Qya, Qoa, QTm, and a composite pre-QTm bedrock unit, by extracting and combining information from a variety of datasets, including existing lithologic and electrical geophysical logs from oil and gas wells and water wells, cross sections, and geologic maps. The framework model was constructed by creating gridded surfaces that represented the altitude of the top of each stratigraphic unit from the input data and then combining these surfaces within a three-dimensional geologic modeling software package. Data from electrical geophysical logs throughout the basin were combined with recent geologic mapping of the Cuyama area to consistently identify the Morales Formation and place the top of the unit within the geologic framework model some 400 to 600 feet deeper than previously published interpretations. The older alluvial unit, Qoa, was not subdivided from younger alluvium on previously published sections. Within the geologic framework model, Qoa is a locally thick unit that includes the lower parts of the previously defined undivided Qya and Qoa and the upper part of the previously defined Morales Formation.

Sediment grain-size data were analyzed in both two and three dimensions to help define textural variations in the Cuyama Valley groundwater basin and to identify areas with similar geologic materials that potentially have fairly uniform hydraulic properties. Sediment grain size was used to construct three-dimensional textural models that employed simple interpolation between drill holes and to construct twodimensional textural models for each stratigraphic unit that incorporated spatial structure of the textural data. The percentage of coarse-grained sediment was calculated from well data for the entire thickness of the Qya, Qoa, and QTm units. These data were extrapolated away from the well data across the study area at 250-meter spacing by using geostatistical methods. The resultant textural models portrayed a coarse-grained younger alluvial unit localized along the Cuyama River and several tributary drainages and a finer-grained older alluvial unit whose textural variations were less tied to the location of the modern drainages. The underlying Morales Formation displayed a broad west-to-east transition from coarse to finegrained deposits. The spatial distribution and modeled textural characteristics of the three basin-filling units are related to the Pliocene and Pleistocene tectonic evolution and uplift of the basin, the progressive narrowing of the valley, and the gradually increasing channelization of the Cuyama River drainage. 


\section{References Cited}

Anderman, E.R., and Hill, M.C., 2000, MODFLOW-2000, The U.S. Geological Survey modular ground-water flow model-Documentation of the hydrogeologic-unit flow (HUF) package: U.S. Geological Survey Open-File Report 2000-342, 89 p.

Anderman, E.R., and Hill, M.C., 2003, MODFLOW-2000, The U.S. Geological Survey modular ground-water flow model-Three additions to the hydrogeologic-unit flow (HUF) package-Alternative storage for the uppermost active cells (STYP parameter type), flows in hydrogeologic units, and the hydraulic conductivity depth-dependence (KDEP) capability: U.S. Geological Survey Open-File Report 2003-347, 36 p. Accessed March 13, 2013, at http://water.usgs.gov/nrp/gwsoftware/modflow2000/ modflow2000.html.

Argus, D.F., and Gordon, R.G., 2001, Present tectonic motion across the Coast Ranges and San Andreas fault system in central California: Geological Society of America Bulletin, v. 113 , p. $1,580-1,592$.

Barger, R.M., and Zulberti, J.L., 1952, Russell Ranch oil field: California Division of Oil and Gas, California Oil Fields Summary of Operations, v. 38, p. 5-10.

Bartow, J.A., 1990, Coarse-grained deltaic sedimentation in the Miocene Cuyama strike-slip basin, California Coast Ranges: Sedimentary Geology, v. 68, p. 17-38.

Bazeley, W.J.M., ed., 1988, Tertiary tectonics and sedimentation in the Cuyama basin, San Luis Obispo, Santa Barbara, and Ventura Counties, California: Society of Economic Paleontologists and Mineralogists, Pacific Section, Book 59, p. 87-98.

Belitz Kenneth, Phillips S.P., and Gronberg, J.M., 1993, Numerical simulation of ground-water flow in the central part of the Western San Joaquin Valley, California: U.S. Geological Survey Water-Supply Paper 2396, 69 p.

Bryant, W.A. (compiler), 2005, Digital Database of Quaternary and Younger Faults from the Fault Activity Map of California, version 2.0: accessed September, 2011 at http://www.consrv.ca.gov/CGS/information/publications/ QuaternaryFaults_ver2.htm.

Burow, K.R., Shelton, J.L., Hevesi, J.A., and Weissmann, G.S., 2004, Hydrogeologic characterization of the Modesto area, San Joaquin Valley, California: U.S. Geological Survey Scientific Investigations Report 2004-5232, 54 p.

Calhoun, J.A., 1986, Structural geology of the Morales Canyon and Taylor Canyon region of the Cuyama basin, southern Coast Ranges, California: Corvallis, Oregon State University, M.S. thesis, 86 p., 18 pls., 9 figs.
California Department of Conservation, 2009, 2008 Annual Report of the State Oil and Gas Supervisor: Division of Oil, Gas and Geothermal Resources Publication PR06, 272 p., accessed February, 2010 at ftp://ftp.consrv.ca.gov/pub/oil/ annual_reports/2008/PR06_Annual_2008.pdf.

California Department of Water Resources, 2003, California's Groundwater-Update 2003: California Department of Water Resources Bulletin 118, Cuyama Valley basin description, accessed May 09, 2012, at http://www.water.ca.gov/pubs/groundwater/bulletin_118/ basindescriptions/3-13.pdf

Davis, T.L., Lagoe, M.B., Bazeley, W.J.M., Gordon, Stuart, McIntosh, Kirk, and Namson, J.S., 1988, Structure of the Cuyama Valley, Caliente Range, and Carrizo Plain and its significance to the structural style of the southern Coast Ranges and western Transverse Ranges, in Bazeley, W.J.M., ed., Tertiary tectonics and sedimentation in the Cuyama Basin, San Luis Obispo, Santa Barbara, and Ventura Counties, California: SEPM (Society for Sedimentary Geology), Pacific Section, v. 59, p. 159-161.

DeLong, S.B., Pelletier, J.D., and Arnold, L.J., 2008, Climate change triggered sedimentation and progressive tectonic uplift in a coupled piedmont-axial system - Cuyama Valley, California, USA: Earth Surface Processes and Landforms, v. 33, p. 1,033-1,046.

DeLong, S.B., Pelletier, J.D., and Arnold, L.J., 2011, Late Holocene alluvial history of the Cuyama River, California, USA: Geological Society of America Bulletin, v. 123, p. 2,160-2,176.

Dibblee, T.W., 1973, Regional geologic map of San Andreas and related faults in Carrizo Plain, Temblor, Caliente, and La Panza Ranges and vicinity, California: U.S. Geological Survey Miscellaneous Investigations Map I-757, scale $1: 125,000$.

Dibblee, T.W. Jr., 1976, The Rinconada and related faults in the southern Coast Ranges, California, and their tectonic significance: U.S. Geological Survey Professional Paper 981, $55 \mathrm{p}$.

Dibblee, T.W. Jr., 1982, Geology of the Alamo Mountain, Frazier Mountain, Lockwood Valley, Mount Pinos, and Cuyama Badlands areas, Southern California, in Fife, D.L. and Minch, J.A., eds., Geology and mineral wealth of the California Transverse Ranges; Mason Hill volume: South Coast Geological Society, p. 57-77.

Dibblee, T.W., Jr., 1995, Tectonic and depositional environment of middle and upper Cenozoic sequences of coastal southern California region, in Fritsche, A.E., ed., Cenozoic paleogeography of the western United States - II: SEPM (Society for Sedimentary Geology), Pacific Section, v. 75, p. 213-245. 
Dibblee, T.W., and Minch, J.A., ed., 2005a, Geologic map of the Ballinger Canyon quadrangle, San Luis Obispo, Santa Barbara, Ventura, and Kern Counties, California: Dibblee Geological Foundation Map DF-170, scale 1:24,000.

Dibblee, T.W., and Minch, J.A., ed., 2005b, Geologic map of the Cuyama quadrangle, San Luis Obispo and Santa Barbara Counties, California: Dibblee Geological Foundation Map DF-176, scale 1:24,000.

Dibblee, T.W., and Minch, J.A., ed., 2005c, Geologic map of the New Cuyama quadrangle, San Luis Obispo and Santa Barbara Counties, California: Dibblee Geological Foundation Map DF-179, scale 1:24,000.

Dibblee, T.W., and Minch, J.A., ed., 2005d, Geologic map of the Peak Mountain quadrangle, San Luis Obispo and Santa Barbara Counties, California: Dibblee Geological Foundation Map DF-181, scale 1:24,000.

Dibblee, T.W., and Minch, J.A., ed., 2006, Geologic map of the Cuyama Peak quadrangle, Santa Barbara and Ventura Counties, California: Dibblee Geological Foundation Map DF-202, scale 1:24,000.

Dibblee, T.W., and Minch, J.A., ed., 2007, Geologic map of the Fox Mountain quadrangle, Santa Barbara County, California: Dibblee Geological Foundation Map DF-260, scale $1: 24,000$.

Ellis, B.J., 1994, Changing tectonic regimes in the southern Salinian block: extension, strike-slip faulting, compression and rotation in the Cuyama Valley, California: Corvallis, Oregon State University, Ph.D. dissertation, 141 p., 31 figs.

Ellis, B.J., and Spitz, H.M., 1987, Subsurface cross-section of the southeastern Cuyama basin, southern California, in Davis, T.L., and Namson, J.S., eds., Structural Evolution of the Western Transverse Ranges: SEPM (Society for Sedimentary Geology), Pacific Section, v. 48A, p. 77-84.

Ellis, B.J., Levi, Shaul, and Yeats, R.S., 1993, Magnetic stratigraphy of the Morales Formation: late Neogene clockwise rotation and compression in the Cuyama Basin, California Coast Ranges: Tectonics, v. 12, p.1170-1179.

Everett, R.R., Gibbs, D.R., Hanson, R.T., Sweetkind, D.S., Brandt, J.T., Falk, S.E. and Harich, C.R., 2013, Geology, water-quality, hydrology, and geomechanics of the Cuyama Valley groundwater basin, California, 2008-12: U.S. Geological Survey Scientific Investigations Report 2013-5108, 62 p.

Faunt, C.C., ed., 2009, Groundwater Availability of the Central Valley Aquifer, California: U.S. Geological Survey Professional Paper 1766, $225 \mathrm{p}$.

Faunt, C.C., Belitz, Kenneth, and Hanson, R.H., 2010, Development of a three-dimensional model of sedimentary texture in valley-fill deposits of Central Valley, California, USA: Hydrogeology, v. 18, p. 625-649
Faunt, C.C., Blainey, J.B., Hill, M.C., D'Agnese, F.A., and O'Brien, G.M., 2010, Chapter F. Transient flow model, in Belcher, W.R., and Sweetkind, D.S., eds., 2010., Death Valley regional groundwater flow system, Nevada and California-Hydrogeologic framework and transient: U.S. Geological Survey Professional Paper 1711, p. 251-344.

Fritsche, A.E., 1988, Origin and paleogeographic development of the Tertiary Cuyama depositional basin, southern California, in Bazeley, W.J.M., ed., Tertiary tectonics and sedimentation in the Cuyama basin, San Luis Obispo, Santa Barbara, and Ventura Counties, California: Pacific Section, Society of Economic Paleontologists and Mineralogists (SEPM), Cuyama symposium and field trip, Guidebook, April 16-18, 1988, v. 59, p. 159-162.

Graham, S.E., Mahony, T.M., Blissenbach, J.L., Mariant, J.J., and Wentworth, C.M., 1999, Regional geologic map of San Andreas and related faults in Carrizo Plain, Temblor, Caliente and La Panza Ranges and vicinity, California: A digital database: USGS Open-File Report 99-14, scale 1:125,000.

Hanson, R.T., Martin, Peter, Koczot, K M., 2003, Simulation of ground-water/surface-water flow in the Santa ClaraCalleguas basin, California: U.S. Geological Survey WaterResources Investigation Report 02-4136, $214 \mathrm{p}$

Hanson, R.T., Li, Zhen, and Faunt C.C., 2004, Documentation of the Santa Clara Valley regional ground-water/ surface-water flow model, Santa Clara County, California: U.S. Geological Survey Scientific Investigations Report 2004-5231, 75 p.

Hardebeck, J.L., and Michael, A.J., 2004, Stress orientations at intermediate angles to the San Andreas Fault, California: Journal of Geophysical Research, v. 109, B11303, doi:10.1029/2004JB003239.

Hill, M. L., Carlson, S.A., and Dibblee, T.W., Jr., 1958, Stratigraphy of Cuyama Valley-Caliente Range Area, California: American Association of Petroleum Geologists Bulletin, v. 42, p. 2,973-3,000.

Hudnut, K.W., Bock, Y., Galetzka, J.E., Webb, F.H., and Young, W.H., 2002, The Southern California Integrated GPS Network (SCIGN), in Fujinawa, Y., and Yoshida, A., eds., Seismotectonics in Convergent Plate Boundary: Terra Scientific Publishing Company, Toyko, p 167-189.

Isaaks, E.H., and Srivastava, R.M., 1989, An Introduction to Applied Geostatistics: Oxford University Press, New York, $561 \mathrm{p}$.

Johnson, D.E., and Pile, K.E., 2002, Well logging in nontechnical language $\left(2^{\text {nd }}\right.$ ed.): Tulsa, Penn Well Publishing Company, $289 \mathrm{p}$.

Journel, A.G., and Huijbregts, C.J., 1978, Mining Geostatistics: Academic Press, New York, 600 p. 
Kellogg, K.S., Minor, S.A., and Cossette, P.M., 2008, Geologic map of the eastern three-quarters of the Cuyama $30^{\prime} \mathrm{x}$ 60 ' quadrangle, California: U.S. Geological Survey Scientific Investigations Map 3002, scale 1:100,000, 2 plates, 1 pamphlet, $23 \mathrm{p}$.

Keys, Scott, and MacCary, L.M., 1971, Application of borehole geophysics to water-resources investigations: U.S. Geological Survey Techniques of Water-Resources Investigations, Chapter E1, Book 2, 126 p.

Lagoe, M.B., 1984, Paleogeography of Monterey Formation, Cuyama Basin, California: American Association of Petroleum Geologists Bulletin, v. 68, p. 610-627.

Lagoe, M.B., 1987, Middle Cenozoic basin development, Cuyama Basin, California, in Ingersoll, R.V. and Ernst, W.G., eds., Cenozoic basin development of coastal California, Rubey Volume VI : Prentice-Hall, Englewood Cliffs, New Jersey, p. 172-206.

Laudon, Julie, and Belitz, Kenneth, 1991, Texture and depositional history of Late Pleistocene-Holocene alluvium in the central part of the western San Joaquin Valley, California: Bulletin of the Association of Engineering Geologists, v. 28, p. 73-88.

Meade, B.J., and Hager, B.H., 2005, Block models of crustal motion in southern California constrained by GPS measurements: Journal of Geophysical Research, v, 110, B03403, doi:10.1029/2004JB003209.

Nevins, B.B., 1982, Structural evolution of the Russell Ranch oil field and vicinity, southern Coast Ranges, California: Corvallis, Oregon State University, M.S. thesis, 76 p., 17 pls., 12 figs.

Page, R.W., 1986, Geology of the fresh ground-water basin of the Central Valley, California, with texture maps and sections: U.S. Geological Survey Professional Paper 1401-C, $54 \mathrm{p}$.

Phillips, S.P., and Belitz, Kenneth, 1991, Calibration of a textured-based model of a ground-water flow system, western San Joaquin Valley, California: Ground Water, v. 29, p. 702-715.

Pierotti, Bob, and Lewy, Richard, 1998, Evaluation of groundwater overdraft in the southern central coast region: California Department of Water Resources, Southern District, Technical Information Record SD-91-1, 13 p.

Schwing, H.F., 1982, Interaction between the Transverse Ranges and Salinian Block in the South Cuyama oil field, Cuyama Valley, California, in Fife, D.L., and Minch, J.A. eds., Geology and mineral wealth of the California Transverse Ranges; Mason Hill volume: South Coast Geological Society, p. 395-402.
Schwing, H.F., 1984, Subsurface Geology of the South Cuyama Oil Field and Adjacent Areas, Southern Coast Ranges, California: Corvallis, Oregon State University, M.S. thesis, 81 p., 19 pls., 10 figs.

Singer, J.A., and Swarzenski, W.V., 1970, Pumpage and ground-water storage depletion in Cuyama Valley California, 1947-66: U.S. Geological Survey Open-File Report 70-304, $24 \mathrm{p}$.

Spitz, H.M., 1986, Subsurface Geology of the Southeastern Cuyama Valley, Southern Coast Ranges, California: Corvallis, Oregon State University, M.S. thesis, 88 p., 20 pls., 12 figs.

Stanley, R.G., 1995, Central Coastal Province (011) with a section on Cuyama Basin, by M.E. Tennyson, in Gautier, D. L., Dolton, G.L., Takahashi, K.I., and Varnes, K.L., eds., 1995 National assessment of United States oil and gas resources-Results, methodology, and supporting data: U.S. Geological Survey Digital Data Series DDS-30, Release 2, one CD-ROM, accessed May 7, 2012 at http://certmapper. cr.usgs.gov/data/noga95/prov11/text/prov11.pdf

Sweetkind, D.S., Bova, S.C., Langenheim, V.E., Shumaker, L.E., and Scheirer, D.S., 2013, Digital Tabulation of Stratigraphic Data from Oil And Gas Wells in Cuyama Valley and surrounding areas, Central California: U.S. Geological Survey Open-File Report 2013-1084, 44 p.

Upson, J.E., and Worts, G.F., 1951, Ground water in the Cuyama Valley, California: U.S. Geological Survey Water Supply Paper 1110-B, 81 p.

Vedder, J.G., 1968, Geologic map of the Fox Mountain quadrangle, Santa Barbara County, California: U.S. Geological Survey Miscellaneous Investigations Map I-547, scale $1: 24,000$.

Vedder, J.G., and Repenning, C.A., 1975, Geologic map of Cuyama and New Cuyama Quadrangles, San Luis Obispo and Santa Barbara Counties, California, U.S. Geological Survey Miscellaneous Geologic Investigations Map I-876, scale 1:24,000, 2 plates.

Wyllie, M.R.J., 1957, The Fundamentals of Electric Log Interpetation ( $2 \mathrm{~d}$ ed.): New York, New York, Academic Press Inc., $176 \mathrm{p}$.

Yeats, R.S., Calhoun, J.A., Nevins, B.B., Schwing, H.F., and H.M. Spitz, 1989, Russell Fault: Early strike-slip fault of California Coast Ranges: American Association of Petroleum Geologists Bulletin v. 73, p. 1,089-1,102.

Zulberti, J.L., 1954, South Cuyama oil field: California Division of Oil and Gas, California Oil Fields Summary of Operations, v. 40, p. 41-45. 


\section{Appendix}

\section{Appendix 1.}

\section{Interpreted depth to top of geologic units in oil and gas wells, Cuyama Valley}

Data compiled within appendix 1 include well location information and subsurface geologic information, such as depths to the geologic unit tops, from oil and gas wells in the Cuyama Valley and surrounding areas. Well names and location data were obtained in a digital well-location database from the California Department of Conservation, Division of Oil, Gas and Geothermal Resources (CA DOGGR) (ftp://ftp.consrv.ca.gov/pub/oil/GIS/ accessed February 2010). Oil and gas exploration holes in the database, and in this report, are referenced by American Petroleum Institute (API) well number, a unique, permanent, numeric identifier assigned to each well drilled for oil and gas in the United States. The numbers reported here are abbreviated versions of the full API well-number and consist of a three-digit county code followed in sequence by a five-digit unique well identification number within the county. County codes are as follows: 079, San Luis Obispo County; 083, Santa Barbara County; 111, Ventura County. Two wells do not have API numbers. The information contained in the CA DOGGR database includes API well number; operator; lease name and well number; section, township, and range; and latitude and longitude. Wells in appendix 1 are identified by API number and a well identifier, which was created by merging the lease name and well number.

Well locations, in meters, are reported in Albers projected coordinate system, North American Datum of 1983 (NAD 83), GRS 80 spheroid. Elevation at the well location, in feet, is reported relative to mean sea level. Values are reported in feet to maintain consistency with source geologic and geophysical data for which depths are reported in feet.

All geologic unit tops are reported in appendix 1 as measured depth - the depth as measured along the length of the borehole. Geologic unit tops with a depth of zero are exposed at land surface and indicate that the well spudded in the listed formation. Subsurface geologic units are listed in stratigraphic order, with stratigraphically highest units on the left and successively lower units to the right. Data columns for some formation tops are preceded by a "less than" symbol in a separate column (LT) that is used to denote cases where the top of the formation is above the start of the electric log, such that the top of the log only provides a maximum value for the drilled depth to the top of the stratigraphic unit. The symbol is listed in a separate column to avoid the appearance of non-numeric characters within the formation tops data column, facilitating use of these data within a geographic information system.
Data compiled within appendix 1 are presented as an EXCEL file that has the following information:

- API number.

- Well identifier.

- $\quad$ Easting, referenced to North American Datum of 1983 (NAD83).

- Northing, referenced to NAD83.

- Elevation of land surface at the well location, referenced to National Geodedic Vertical Datum of 1988 (NGVD88).

- Total depth of the well.

- Drilled depth to older alluvium, Qoa.

- Drilled depth to the Morales Formation, QTm.

- Drilled depth to the Quatal Formation, Tq.

- Drilled depth to bedrock units 1 or 2, BR1 or BR2. 


\section{Appendix 2.}

\section{Interpreted depth to top of geologic units in water wells, Cuyama Valley}

Data compiled within appendix 2 include well location information and depths to geologic unit tops for older alluvium, Qoa, and the Morales Formation, QTm from water wells in the Cuyama Valley and surrounding areas. Well location data were obtained in a digital form from the US Geological Survey (USGS) National Water Information System web page (NWIS Web, http://waterdata.usgs.gov/nwis/ accessed July 2012). Wells in appendix 2 are identified by a well identifier that take one of the following forms: (1) a well name, such as 10/25-19P1, from Upson and Worts (1951); (2) a well name, such as PT-18 or CUY-40, from Everett and others (2013); or (3) a well name, such as CUY-G-05, that is unique to this report. Some wells appear in both Upson and Worts (1951) and Everett and others and are given identifiers from both reports.

Well locations, in meters, are reported in Albers projected coordinate system, North American Datum of 1983 (NAD 83), GRS 80 spheroid. Elevation at the well location, in feet, is reported relative to mean sea level. Values are reported in feet to maintain consistency with source geologic and geophysical data for which depths are reported in feet.

All geologic unit tops are reported in appendix 2 as measured depth, the depth as measured along the length of the borehole. Geologic unit tops with a depth of zero are exposed at land surface and indicate that the well spudded in the listed formation. Some wells are interpreted to have bottomed within younger alluvium (Qya), such that the total depth of the log provides a minimum value for the drilled depth to the top of the underlying unit, Qoa. For these wells, interpreted depth to the top of Qoa is preceded by a "greater than" symbol in a separate column (GT) that is used to denote cases where the top of the formation is interpreted to lie below the bottom of the well. The symbol is listed in a separate column to avoid the appearance of non-numeric characters within the formation tops data column, facilitating use of these data within a geographic information system.
Data compiled within appendix 2 are presented as an EXCEL file that has the following information:

- Well identifier.

- $\quad$ Easting, referenced to North American Datum of 1983 (NAD83).

- $\quad$ Northing, referenced to NAD83.

- Elevation of land surface at the well location, referenced to National Geodedic Vertical Datum of 1988 (NGVD88).

- Total depth of the well.

- $\quad$ Drilled depth to older alluvium, Qoa.

- Drilled depth to the Morales Formation, QTm.

- $\quad$ Source of lithologic data.

\section{References Cited}

Everett, R.R., Gibbs, D.R., Hanson, R.T., Sweetkind, D.S., Brandt, J.T., Falk, S.E. and Harich, C.R., 2013, Geology, water-quality, hydrology, and geomechanics of the Cuyama Valley groundwater basin, California, 2008-12: U.S. Geological Survey Scientific Investigations Report 2013-5108, 62 p. 


\section{Appendix 3.}

\section{Sediment textural characteristics interpreted from electric logs from oil and gas wells, Cuyama Valley}

Data compiled within appendix 3 include well location information and sediment textural characteristics as interpreted from electric logs from oil and gas wells in Cuyama Valley and surrounding areas. Well names and location data were obtained in a digital well location database from California Department of Conservation, Division of Oil, Gas and Geothermal Resources as described in appendix 1.

Interpreted sediment texture for down-hole intervals is reported along with a corresponding grain-size class. The geologic unit predicted to be present at each depth was determined by vertically intersecting the geologic framework model at the location of each well.

The EXCEL file that contains the sediment textural characteristics from oil and gas wells in Cuyama Valley has two worksheets. The first worksheet is labeled "Table A3_1 Well location" and contains the following information:

- American Petroleum Institute (API) well number.

- Well identifier, created by merging the lease name and well number.

- Easting, referenced to North American Datum of 1983 (NAD83).

- $\quad$ Northing, referenced to NAD83.

- Elevation of land surface at the well location, referenced to National Geodedic Vertical Datum of 1988 (NGVD88).

- Total depth of the well.

The second worksheet is labeled "Table A3_2 Texture" and contains the following information:

- API number.

- Interpreted lithology.

- Grain-size class.

- Top of interval.

- Base of interval.

- Interval thickness.

- Geologic unit from Framework.

\section{Appendix 4.}

\section{Sediment textural characteristics interpreted from drillers' lithologic logs from water wells, Cuyama Valley}

Data compiled within appendix 4 include well location information and sediment textural characteristics as interpreted from drillers' lithologic logs from water wells in Cuyama Valley and surrounding areas. Well names and location data were assigned in the fashion described in appendix 2.

The drillers' lithologic description for down-hole intervals is reported along with a corresponding grain-size class and sorting parameter. Records for water wells obtained from the California Department of Water Resources are confidential. For these wells, the drillers' lithologic descriptions were not tabulated; only the grain-size class and sorting parameter interpreted from the descriptions were tabulated. The stratigraphic unit predicted to be present at each depth was determined by vertically intersecting the geologic framework model at the location of each well.

The EXCEL file that contains the sediment textural characteristics from oil and gas wells in Cuyama Valley has two worksheets. The first worksheet is labeled "Table A4_1 Well location" and contains the following information:

- Well identifier.

- $\quad$ Easting, referenced to North American Datum of 1983 (NAD83).

- Northing, referenced to NAD83.

- Elevation of land surface at the well location, referenced to National Geodedic Vertical Datum of 1988 (NGVD88).

- Total depth of the well.

- Source of lithologic data.

The second worksheet is labeled "Table A4_2 Texture" and contains the following information:

- Well identifier.

- Top of interval.

- Base of interval.

- Interval thickness.

- Lithologic description.

- Grain-size class.

- $\quad$ Sorting.

- Geologic unit from Framework. 
Prepared by the Sacremento Publishing Service Center.

For more information concerning this report, contact:

Director

U.S. Geological Survey

California Water Science Center

6000 J Street, Placer Hall

Sacramento, CA 95819

dc_ca@usgs.gov

or visit our Web site at:

http://ca.water.usgs.gov 




